\title{
IRMAPE
}

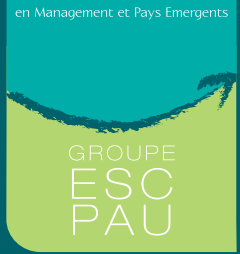

\section{CAHIERdeRECHERCHE N¹2}

Institut de Recherche en MAnagement et Pays Emergents du Groupe ESC PAU

The Groupe ESCPAU Institute for Research in Management and Emerging Countries 


\section{Préambule}

"Ecrire n'est pas l'élément neutre de la Recherche mais au contraire contribue à la révéler. Alors, considérer dès le départ l'écriture comme ressort essentiel du travail à effectuer permettra d'en déployer toute la potentialité formatrice.

Une telle démarche ne va pas de soi. Aussi, il convient de la mettre largement à l'épreuve, d'en expérimenter les effets dans d'autres contextes, d'accompagner sa recherche avec elle et de mettre à profit différentes rencontres possibles autour d'elle, le retour de la part des autres étant essentiel pour savoir ce que l'on a écrit ».

L'écriture produit ou modifie la pensée et ses formes.

Yves REUTER 


\section{Composition et présentation du Comité de Lecture}

Monsieur Gérard HIRIGOYEN

Président du Pôle Universitaire de Bordeaux

Monsieur Paul LE CANNU

Professeur à l'Université de Paris I - Panthéon Sorbonne

Monsieur Gérard DENIS

Professeur et Doyen de l'Université de Pau et des Pays de l'Adour

Monsieur Bertrand SAPORTA

Professeur Emérite de Sciences de Gestion à l'Université Montesquieu-Bordeaux IV

Monsieur Christian PRAT DIT HAURET

Professeur à l'Université Montesquieu-Bordeaux IV

Monsieur Thierry POULAIN REHM

Maître de Conférences à l'Université Montesquieu-Bordeaux IV

Monsieur ALI YAKHLEF

Professeur à l'Université de Stockholm

Madame Anne NELSON

Professeur en Systèmes d'Informations à High Point University 


\section{Sommaire}

A Framework for Measuring Supply Chain Agility: The Performance Metrics Approach Page 5 Par Faizul Huq, Phillipe Lafontaine

Par Anne Nelson

L'individu comme « ensemble des relations sociales »:

Par Dr. Patrice Cailleba

The Trinity of International Strategy: Adaptation, Standardization and Transformation.

Par Ali Yakhlef 


\section{A Framework for Measuring Supply Chain Agility: \\ The Performance Metrics Approach}

By Faizul Huq

Ohio University

By Phillipe Lafontaine

IRMAPE, France 


\section{Abstract}

Supply chain strategies have undergone tremendous changes in response to dynamic external pressures. Companies have outsourced and partnered with suppliers to reduce complexity in their SCM. There is experimentation with various supply chain innovations incorporating agility. To successfully implement an agile supply chain, companies have to establish high "levels of cooperation and partnership among the supply chain partners. As agility depends on qualitative factors like level of cooperation and partnership", it is necessary to have controlled and structured methodology of decision making. Performance measures play an important role in helping companies measure the qualitative aspects of agility. Companies can use these metrics to retrospect their strategies and take corrective steps to enhance agility in their supply chains. Importance of performance measures takes even more prominence to ensure adequate controls on the supply chain in the changed business models of virtual and extended enterprise. This paper proposes a framework to help management in decision making to move towards agile supply chains with the help of performance metrics.

Keywords: Supply Chain Management, Agility, Performance Measures, Metrics 


\section{Introduction}

Owing to the recent trends in international procurements, new information technologies, increasing pressure from customers on responsiveness and reliability, and globalization of operations and markets, supply chain management (SCM) has become a challenge and an opportunity for companies to explore (Bowersox \& Closs, 1996). In today's competitive environment, if there is anything constant that is change. To survive such an environment, companies have to develop an inherent ability to quickly respond to these changes.

Supply chain strategies have undergone tremendous changes in response to these dynamic external pressures. Companies have started outsourcing and partnering with other enterprises to reduce complexity of their SCM. Companies are experimenting with various supply chain innovations to reduce cost, and generate revenues by achieving greater levels of customer satisfaction. To satisfy ever-demanding customer the supply chain strategies have aimed towards incorporating agility. To successfully implement an agile supply chain, companies have to establish high levels of cooperation and partnership among the supply chain partners. As agility depends on qualitative factors like "level of cooperation and partnership", it is necessary to have controlled and structured methodology of decision making. Performance measures play an important role in helping companies measure the immeasurable. Companies can use these metrics to retrospect their strategies and take corrective steps to enhance agility in their supply chains. Importance of performance measures takes even more prominence to ensure adequate controls on the supply chain in the changed business models of virtual and extended enterprise. As Victor Fung, CEO of Li \& Fung, had identified that success increasingly depends on the ability to control what happens in the value chain outside company boundaries (Magretta, 1998). This paper aims to propose a framework to help management in decision making to move towards agile supply chains with the help of performance metrics. Second section describes a brief literature review of supply chain management and discusses the need for agile supply chains. As the next step, characteristics of agile supply chains are discussed, which forms the basis for developing the performance metrics. A framework is then proposed to develop weights for the metrics. Finally the necessity of performance metrics in controlling the effectiveness of supply chain is explained with the help of a case study.

\subsection{Need for Agile Supply Chain/Supply Chain Management}

The business concept known as SCM has forever changed the way in which companies move their goods to market. It has impacted every stage of the supply chain process - from the initial sourcing of raw materials to the final point of sale. The Supply Chain Council defines SCM as "the effort involved in producing and delivering a final product from the supplier's supplier to the customer's customer". Supply chain encompasses all of the activities with moving goods from the raw materials stage through to the end user. These activities include procurement, production scheduling, order processing, inventory management, transportation, warehousing, and customer service (Ganeshan, 1999). SCM is about coordinating all these activities to deliver value to the customer. Performance Measurement Group, a subsidiary of Pittilgio Rabin Todd \& McGrath (PRTM) consulting, conducted a research documenting the link between supply chain and profitability. The research found that market leaders were able to reduce their costs by 5 to 6 percent of sales by implementing efficient supply chain management policies. For a company with $\$ 500$ million in sales, the savings amount to $\$ 25-30$ million per year. Among many potential factors, six business and economic factors would have significant impact on the future of supply chain management. These are consumer demand, globalization, competition, information and communications, government regulations and environment (David and Yossi Sheffi, 1998).

The 1980s and 1990s were termed as the decades of globalization. As cost of manufacturing increased in developed countries, companies started to search for cost effective alternative production bases. The process of globalization was further aided by liberalization and opening up of third world economies. 
This facilitated in expanding the supply chain activities across the world. A global corporation's supply chain consists of multiple enterprises located around the world and each enterprise is involved in a wide variety of activities. A prominent executive from Ryder quoted, "The production base will shift to the lowest cost place. Today it is Southeast Asia, tomorrow it would be South America and then Africa." While the globalization of many industries has created many opportunities for the participants, it also brought to the customer a wide variety of products that further increased his expectations. One of the biggest challenges facing organizations today is the need to respond to ever-increasing volatility in consumer demand. The 1990s have seen a new driving force in corporate strategy: delighting global customers (Anderson \& Lee, 1999). To delight the customer, companies are competing to reach customer first. With the emergence of e-commerce and new ways of retailing, old channels are undergoing change. Product life cycles, particularly in high-tech sector, have grown shorter stressing the importance of speed to market (refer to Box-I), and low cost of obsolescence. All these factors are increasing the complexity of supply chain management.

Most of the supply chain management tools of 1980s and 1990s including material resource planning (MRP), JIT production, kanban, continuous improvement, and total quality management focused on traditional issues of cost control and improving operating performance. However, companies have realized that these traditional SCM tools were not sufficient to meet the increasingly volatile customer demands cost effectively. This necessity gave birth to a new concept named "Agile Supply Chains".

Box - I

Martin Christopher in his article draws an analogy between the supply chain and an oil pipeline. Long pipelines tend to have more oil in them than shorter ones. If demand at the other end changes to a different grade oil, then longer the pipeline, the longer the time needed to respond to that changed demand. Christopher further quotes, "Since agility is nothing but the ability to change rapidly, the total "end-to-end" time in the supply chain directly impacts responsiveness. In a supply chain for complex products with many components, the slowest moving element will determine the pipeline length." So even if ninety-nine out of a hundred component items are available within days, the hundredth component with a three-month lead-time determines the overall response time of the supply chain.

\subsection{Agile Supply Chains}

In 1991, a US government sponsored workshop was held at Lehigh University that gave birth to the concept of the agile manufacturing enterprise as a successor to Lean manufacturing. The participants had agreed that the pace of change in the business environment was outpacing the capabilities of many established organizations. The workshop concluded that companies would survive based on their ability to keep up with continuous and unexpected change. The workshop coined the term "Agility" and loosely defined it as "the ability of an organization to thrive in a continuously changing, and unpredictable business environment. Being agile means being dynamic enough to seize the market opportunities as well as to initiate innovations. In 1995, Steven Goldman and his colleagues drew international attention to "agility" through their book "Agile Competitors and Virtual Organization".

Rachel Mason-Jones, Ben Naylor and Denis R. Towill defined agility as using market knowledge and a virtual corporation to exploit profitable opportunities in a volatile market place (Mason-Jones, Naylor \& Towill, 2000). Volatility of market demand is the key factor driving the need for agility in supply chains. The businesses should not only cope with, but also exploit this volatility to their strategic advantage. Customer service level ie, availability of products/services in the right place at the right time, would be the market winner in serving a volatile market place. 
There is a fundamental difference between the traditional approach to supplying product to markets and the newly emerging model (refer to Table-I). The traditional approach aimed at minimizing production, material handling and transportation costs by using economic batch quantities. Finished product is produced based on a forecast and is then held as inventory, awaiting customer orders. However, in the agile model goods are produced, moved or stored in response to a known customer requirement. Based on point-of-sale data during the initial stages of product life cycle or a real customer order, company's produce the final product. For example, a paint manufacturer would produce paints in most generic form and store them in warehouses near the customer. When a customer places an order for a particular shade, the paints in generic form are mixed in appropriate proportion to make the desired shade. Thus agile supply chains facilitate in customizing the product to meet the individual customer's needs and develop new products and services in a short time span.

\begin{tabular}{|l|l|}
\hline Traditional Approach & Agile Approach \\
\hline $\begin{array}{l}\text { Stock is held at multiple echelons, } \\
\text { often based on organizational and } \\
\text { legal ownership considerations. }\end{array}$ & $\begin{array}{l}\text { Stock is held at the fewest echelons, } \\
\text { if at all with finished goods sometimes being } \\
\text { delivered direct from factory to customer. }\end{array}$ \\
\hline $\begin{array}{l}\text { Replenishment is driven } \\
\text { sequentially by transfers from one } \\
\text { stocking echelon to another. }\end{array}$ & $\begin{array}{l}\text { Replenishment of all echelons is } \\
\text { driven from actual sales/usage data } \\
\text { collected at the customer interface. }\end{array}$ \\
\hline $\begin{array}{l}\text { Production is planned by discrete } \\
\text { organizational units with batch } \\
\text { feeds between discrete systems. }\end{array}$ & $\begin{array}{l}\text { Production is planned across functional } \\
\text { boundaries from vendor to customer, } \\
\text { through highly integrated systems, } \\
\text { with minimum lead-times. }\end{array}$ \\
\hline $\begin{array}{l}\text { Majority of stock is fully finished } \\
\text { goods, dispersed geographically } \\
\text { waiting to be sold. }\end{array}$ & $\begin{array}{l}\text { Majority of stock is held as } \\
\text { "work-in-progress" awaiting } \\
\text { build/configuration instructions. }\end{array}$ \\
\hline
\end{tabular}

Table - I: Comparison of Traditional and Agile Supply Chains

Source: Martin Christopher "Creating the Agile Supply Chain" http://christopher.ascet.com.

\section{Characteristics of agile supply chains}

Martin Christopher (1999) notes four key distinguishing characteristics of agile supply chains as Market sensitivity, Virtual integration, Process integration, and Network based.

\subsection{Market Sensitivity}

An agile supply chain should be capable of reading and responding to real demand and not forecasted demand (Christopher, 1999). Most organizations make forecast based on past sales shipments rather than actual demand due to lack of data on actual customer behavior. One of the major breakthroughs in the last decade was (ECR) Efficient Consumer Response. The ECR initiative, transforms the supply chain from a "push system" to a" pull system" where channel partners form new interdependent relationships and product replenishment is driven by point of sale (POS) data (Bhutta \& Huq, 2000). With this real time data, more accurate forecasts of the demand are being made and fulfilled with low inventories and obsolescence. 
One of the barriers to direct human interaction in the supply chain is the geographical separation of its members. Virtual integration can overcome these geographical barriers (Bal, Wilding \& Gundry, 2000). Sharing of data between buyers and suppliers using information technology is creating a virtual supply chain, which is information based rather than inventory based (Christopher, 1999). All the players in the entire supply chain are connected electronically, either through EDI or Internet. This would not only facilitate real time information sharing between all the players in the supply chain but also increase the ability of members to behave as a team, sharing knowledge and expertise, regardless of location (Jay, Bal, Wilding, Gundry 2000). Virtual Integration is crucial for the success of Agile Supply Chains.

\subsection{Process Integration}

Process integration helps in collaborative working between buyers and suppliers, in various aspects of supply chain management like joint product development, inventory management, routing of goods etc. For example, collaboration in product development with supplier using concurrent engineering principles would help develop a manufacturable product with minimum of lead-time and cost. This type of integration is termed as "extended enterprise" (Siverts). Co-operation in the supply chain is increasingly necessary as companies have started focusing more on managing their core competencies and outsource all other activities. For instance, the automobile industry is moving up the value chain to manage the service aspect of the product and leaving the manufacturing to its suppliers. For the success of process integration, trust and commitment must prevail coupled with joint strategy determination, buyer-supplier teams, transparency of information and even open-book accounting (Christopher, 1999).

\subsection{Network Based}

It is now widely recognized that individual businesses no longer compete as stand-alone entities but rather as supply chains. It has become an era of "network competition", where the winner is the one who can better structure, coordinate, and manage the relationships with their partners in a network (Christopher, 1999). The task of building a strong relationship between all the partners of supply chain is enormous in nature. However, prominent companies have created an extended supply chain "communities" that leverage the core competencies of each partner. These communities work to optimize their efforts for seamless flow of materials and information through the supply chain pipelines. This would make the organization nimble, gaining the ability to respond to customers faster and more accurately than before. 


\section{Framework}

Van Hoek (1998) highlighted the need for new performance measurement systems due to complexity of supply chains and new characteristics of emerging organization. Traditional performance measures might fall short in helping management with decisions to enhance agility in the supply chain. A challenge for today's organizations would be to develop and implement a new measurement system that can help management in decision-making.

The proposed measurement and control framework would provide management with a set of actions that can be taken in enhancing the agility in supply chains. The framework is distinct from passive administrative tradition and helps in directing management attention towards areas of long term strategy improvement. For such measurement system, this article proposes the use of Multiple Attribute Utility Theory (MAUT) that can effectively deal with both quantitative and qualitative factors. MAUT enables the decision maker to structure a complex problem in the form of a simple hierarchy and to subjectively evaluate a large number of quantitative and qualitative factors in the presence of risk and uncertainty (Keeney, 1976).

The following is the proposed framework:

Step1: Identify and interpret the performance metrics depending on the nature of industry.

Step2: Interview the decision makers for information concerning the attributes and determine the best and worst possible values of the attributes.

Step3: Determine the type of utility function and develop decision maker's utility function.

Step4: The weights for each attribute are calculated using Probability-Assessment Technique.

Step5: Provide employees with the overall utility function which would help them make appropriate decisions within their responsibility.

\subsection{Probability Equivalent Assessment Technique}

The probability-equivalent (PE) assessment technique is similar to certainty equivalent approach. The PE technique considers the relative desirability of one attribute at its most preferred level and all other attributes at their worst level. In this technique, the probability $p$ that makes the decision maker indifferent between the option 1 (sure thing) and option 2 (lottery) has to be determined. The option 1 is set to the best on one attribute and worst on all other attributes. The Option 2 (lottery) is between best values on all attributes and worst values on all attributes. The probability $\boldsymbol{p}$ is the weight (scaling constant) of the odd attribute in option 1 . To determine the value of $p$ (scaling constant), the decision maker has to answer the following question: "For what probability would he be indifferent between option 1 yielding attribute $x 1$ at its best and all other attributes at their least desirable levels and an alternative option 2 consisting of a lottery yielding all attributes at their most desirable level with probability $\boldsymbol{p}$ or otherwise all attributes at their least desirable level?" (Keeney, 1976). 
Option 1

Attribute $\boldsymbol{x} \mathbf{1}$ at its best level and all other attributes at their worst level
Option 2

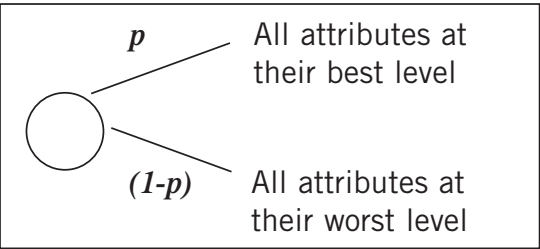

Figure I

\subsection{Performance Measures of the Agile Supply Chains}

Performance measures are developed based on the characteristics of agile supply chains proposed by Martin Christopher. These performance measures were developed from a perspective of a typical manufacturing company as shown below in Table III.

\begin{tabular}{ll}
\hline Characteristic & Performance Measures \\
\hline Market Sensitivity & - Number of stock out situations \\
& - Number of discount sales at the end of the season \\
& - Opportunity loss for not being first to market in a product category. \\
\hline Virtual Integration & - Percentage of purchases/orders made electronically \\
& - Number of stoppages of production runs due to material shortages \\
& - Percentage of virtual meetings of global teams during project duration \\
\hline Process Integration & - Percentage of correct order fulfillments \\
& - Percentage of orders meeting the due dates \\
& - Design-to-delivery cycle time \\
& - Time to Volume \\
\hline Network Based & - Percentage of customer orders fulfilled by manufacturing partners itself \\
& - Cash-to-Cash cycle time. \\
& - Reorder replenishment cycle time. \\
\hline
\end{tabular}

Table-III

Number of stock out situation/discount sales at the end of the season: In agile supply chain management model, firms estimate the demand based on point of sale data. Any miscalculation of demand on the part of firm would either lead to stock out situations or excess inventory, both of which are costs to the company.

Opportunity loss for not being first to market: A market sensitive company would be able to identify the changing customer tastes for a new product and proactively incorporate them into its products and reach the market before its competitors.

Percentage of purchases made electronically: A virtually integrated firm should completely place its purchase orders electronically thus eliminating manual purchase order processing by the suppliers. 
Number of production run stoppages due to material shortages: Virtual integration should facilitate seamless flow of information along the supply chain. However, due to communication gap with suppliers, a production run has to be stopped if the materials do not reach the shop floor.

Percentage of virtual meetings of global teams during project duration: Virtual integration facilitates knowledge sharing by forming virtual teams comprising of people from all over the world. The strength of virtual integration in the firm could be gauged by the average number of virtual meetings held by the global teams.

Percentage of correct order fulfillment/orders meeting due dates: If the processes of the company and its suppliers are perfectly integrated then all the orders would reach the correct place within the due dates.

Design-to-Delivery cycle time: It is the time taken for a product to evolve from conceptual stage to reach the market as a real tangible product. Due to shrinking product life cycles, companies have to reduce their product development lead times. Since the profit margins in the early part of the product life cycle are greatest, the potential sales gains from being first to the market are tremendous. With process integration, concurrent engineering principles can be employed and a manufacturable product can be developed without any manufacturing and assemble complexities.

Time-to-volume: High level of process integration expedites product development, product distribution, efficient inventory management, etc., with higher product quality. For example, in an integrated product development environment Engineering change orders (ECOs) update the bill of materials (BOM) database, which in turn feeds customer configuration and manufacturing systems. These systems are shared with key suppliers allowing them to make corresponding design changes to their components. Such coordinated action would reduce time-to-volume.

Percentage of customer orders fulfilled by manufacturing partners: The supply chain network should be strong to deliver value to customer. A customer approaching OEM for a spare part should not have to wait too long for the reason that the part has to be made by a Tier II supplier. The network should be coordinated by OEM in such a way that the supplier should be able to ship the product directly from his plant.

Cash-to-Cash cycle time: The length of the supply chain should be small to respond quickly to any changes in the external market. The length of supply chain can be measured by cash-to-cash cycle time.

Average length of relationship time with immediate suppliers and distributors: The degree of trust between network participants should be high for improving time and quality performance. Such levels of trust evolve over a period of time.

Reorder replenishment cycle time: If there is a sudden and unpredictable demand for the product then OEM should be able to pull up its entire supply chain to meet the demand. The supplier's willingness to stretch themselves to meet the OEM requirements depends to a large extent on the strength of their relationship.

These performance metrics coupled with the decision framework would help companies control and monitor their strategies. A case study is discussed to show the utility of the framework. 


\section{Case study}

The XYZ Trucking Company is one of the largest trucking companies (Third Party Logistics provider) in the US. The Company had annual revenue of $\$ 5$ billion over an asset base of $\$ 5.8$ billion. With its headquarters in US, the company has spread its operations in North America, Latin America, Europe and Asia to serve its clients needs. The company's traditional product offering include dedicated contract carriage and carrier management. The company has over 14,000 customers operating 170,000 vehicles in US, Canada and United Kingdom.

The company has initiated various measures to make its supply chain agile and nimble. Performance measures were used to ensure that the initiatives adopted are on the right track.

As the first step of the framework, the metrics are identified and interpreted to suit the company. For example, the generic metric "average length of relationship" can be interpreted as "percentage of contract renewals" for a Third party logistics provider like our trucking company.

The senior executives at the company are interviewed to decide on the range of values for each attribute, over which the utility function can be assessed. These ranges are necessary to calculate scaling constants and set priorities among the metrics for decision making. The overall utility function can be represented as below:

$\mathrm{U}\left(\mathrm{u}_{1}, \mathrm{u}_{2}, \ldots . \mathrm{u}_{\mathrm{i}}\right)=\mathrm{k}_{1} \mathrm{u}_{1}+\mathrm{k}_{2} \mathrm{u}_{2}+\ldots .+\mathrm{k}_{\mathrm{i}} \mathrm{u}_{\mathrm{i}}$

Where $u_{i}, i=1,2,3 \ldots .9$ are the utility functions of the metrics

and $\mathrm{k}_{\mathrm{i}}, \mathrm{i}=1,2,3 \ldots .9$ are scaling constants or weights of the metrics.

The utility function here is additive in nature.

The scaling constants (weights) are calculated using Probability-Equivalent Assessment technique. For example, let us take the example of determining the scaling constant for the attribute 4 ie, percentage of correct orders fulfillment. The trade off decision tree is shown in figure II. The utility values for the best and worst of these attributes is
$\mathrm{U}_{1}(0)=1$
$\mathrm{U}_{1}(100)=0$
$\mathrm{U}_{2}(100)=1$
$\mathrm{U}_{2}(0)=0$
$\mathrm{U}_{3}(100)=1$
$\mathrm{U}_{3}(0)=0$
$\mathrm{U}_{4}(100)=1$
$\mathrm{U}_{4}(0)=0$
$\mathrm{U}_{5}(100)=1$
$\mathrm{U}_{5}(0)=0$
$\mathrm{U}_{6}(2$ Weeks $)=1$
$\mathrm{U}_{6}(6$ weeks $)=0$
$\mathrm{U}_{7}(100)=1$
$\mathrm{U}_{7}(0)=0$
$\mathrm{U}_{8}(100)=1$
$\mathrm{U}_{8}(0)=0$
$\mathrm{U}_{9}(2$ weeks $)=1$
$\mathrm{U}_{9}(6$ weeks $)=0$

To determine the scaling constant for attribute 4, the decision maker has to answer the question: "For what probability would he be indifferent between option 1 consisting of a lottery yielding all attributes at their most desirable level with probability $p$ or otherwise all attributes at their least desirable level and an alternative option 2 yielding attribute percentage of correct order fulfillment at its best ie, $100 \%$ and all other attributes at their least desirable levels?" The decision maker is indifferent between the option 1 and option 2 (best on percentage of correct order fulfillment) at $p=0.18$. The indifference 
equation can be written as

$\mathrm{k}_{1} \mathrm{U}_{1}(100)+\mathrm{k}_{2} \mathrm{U}_{2}(0)+\mathrm{k}_{3} \mathrm{U}_{3}(0)+\mathrm{k}_{4} \mathrm{U}_{4}(100)+\mathrm{k}_{5} \mathrm{U}_{5}(0)+\mathrm{k}_{6} \mathrm{U}_{6}(6$ weeks $)+$

$\mathrm{k}_{7} \mathrm{U}_{7}(0)+\mathrm{k}_{8} \mathrm{U}_{8}(0)+\mathrm{k}_{9} \mathrm{U}_{9}(6$ weeks $)$

$=0.18\left[\mathrm{k}_{1} \mathrm{U}_{1}(0)+\mathrm{k}_{2} \mathrm{U}_{2}(100)+\mathrm{k}_{3} \mathrm{U}_{3}(100)+\mathrm{k}_{4} \mathrm{U}_{4}(100)+\mathrm{k}_{5} \mathrm{U}_{5}(100)\right.$

$+\mathrm{k}_{6} \mathrm{U}_{6}(2$ weeks $)+\mathrm{k}_{7} \mathrm{U}_{7}(100)+\mathrm{k}_{8} \mathrm{U}_{8}(100)+\mathrm{k}_{9} \mathrm{U}_{9}(2$ weeks $\left.)\right]+0.82\left[\mathrm{k}_{1} \mathrm{U}_{1}\right.$

$(100)+\mathrm{k}_{2} \mathrm{U}_{2}(0)+\mathrm{k}_{3} \mathrm{U}_{3}(0)+\mathrm{k}_{4} \mathrm{U}_{4}(0)+\mathrm{k}_{5} \mathrm{U}_{5}(0)+\mathrm{k}_{6} \mathrm{U}_{6}(6$ weeks $)+\mathrm{k}_{7} \mathrm{U}_{7}(0)$

$+\mathrm{k}_{8} \mathrm{U}_{8}(0)+\mathrm{k}_{9} \mathrm{U}_{9}(6$ weeks)]

Substituting the utility values we get $\mathrm{k}_{4}=0.18\left(\mathrm{k}_{1}+\mathrm{k}_{2}+\mathrm{k}_{3}+\mathrm{k}_{4}+\mathrm{k}_{5}+\mathrm{k}_{6}+\mathrm{k}_{7}+\mathrm{k}_{8}+\mathrm{k}_{9}\right)$

Since the utility of additive function is $k_{1}+k_{2}+k_{3}+k_{4}+k_{5}+k_{6}+k_{7}+k_{8}+k_{9}=1$

Therefore $\mathrm{k}_{4}=0.18$.

Repeating the same procedure, we can find the rest of the values of scaling constants.

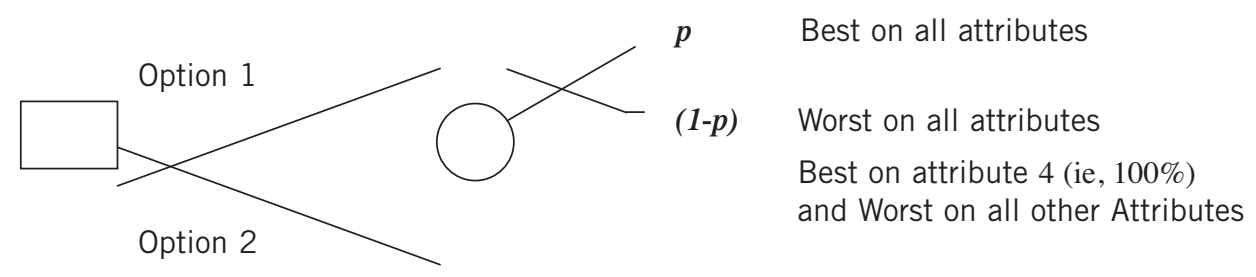

Figure II

\begin{tabular}{|c|c|c|c|c|c|}
\hline SNO & Performance Measure & Best Value & Worst Value & Weight (kp) & Rank \\
\hline & Market Sensitivity (0.06) & & & & \\
\hline \multirow[t]{2}{*}{1.} & $\begin{array}{l}\text { Number of discount sales at the end of the season } \\
\text { Percentage of Volume on discount pricing) }\end{array}$ & 0 & 100 & 0.06 & 9 \\
\hline & Virtual Integration (0.25) & & & & \\
\hline 2. & $\begin{array}{l}\text { Percentage of virtual meetings (with clients) } \\
\text { during project duration }\end{array}$ & 100 & 0 & 0.13 & 3 \\
\hline \multirow[t]{2}{*}{3.} & Percentage of orders taken electronically & 100 & 0 & 0.12 & 4 \\
\hline & Process Integration (0.43) & & & & \\
\hline 4. & Percentage of correct orders fulfillment & 100 & 0 & 0.18 & 1 \\
\hline 5. & Percentage of orders meeting the due dates & 100 & 0 & 0.15 & 2 \\
\hline \multirow[t]{2}{*}{6.} & Design-to-delivery cycle time (New service concept) & 2 Weeks & 6 Weeks & 0.10 & 6 \\
\hline & Network Based (0.26) & & & & \\
\hline 7. & $\begin{array}{l}\text { Average Length of relationship time } \\
\text { (Percentage of contract renewals) }\end{array}$ & 100 & 0 & 0.11 & 5 \\
\hline 8. & $\begin{array}{l}\text { Reorder replenishment cycle time (Percentage } \\
\text { of times clients additional requests for service } \\
\text { has been accommodated) }\end{array}$ & 100 & 0 & 0.08 & 7 \\
\hline 9. & Cash-to-cash cycle time & 2 Weeks & 6 Weeks & 0.07 & 8 \\
\hline
\end{tabular}

Table IV

Level of Importance of Performance Metrics for Trucking Industry 
Insights from Value Assessment: All major decision making processes from selecting new supplier to investing in IT to setting up new facilities can be structured using this framework. For example, the company decides to make fresh investments to increase its customer service level. A typical approach would be to split the investment equally to improve performance of the company as measured by various attributes. It does not consider the relative importance of the attributes. With the above-mentioned framework the investments can be prioritized. Since process integration is very important with a weight of 0.43 , more investment should be diverted towards setting new systems or enhancing the existing system for better process integration. Based on this information, the company has prioritized its strategies and action plan to achieve agility in its supply chain. Such prioritizing helped the company in effectively utilizing time and budget. The company was able to concentrate more on value adding activities and enhance its service delivery.

The utility functions can be used to conduct a deficiency analysis by indicating the difference between the present state and a desired state (Keeney, Raiffa, 1976). By calculating the gradient of the utility function of each attribute for the present state and combining this with subjectively assessed changes in the state of each attribute for an equivalent amount of effort (time and money), one gets an indicator of policies that may be particularly fruitful to pursue. Alternatively, impact analysis can be performed by value assessment of the attributes. Given the utility function, any specified impact on the one attribute and equivalent valued impact on another attribute can be calculated. A useful way of examining value trade-offs is in terms of economic impacts ie, in dollar terms. From the judgment of Operations Managers of the company, a decrease in percentage of correct order fulfillments (attribute 4 ) by $6 \%$ would result in losing 20 customers and an annual loss of $\$ 1000,000$ in revenues. Thus, if the company can enhance its level of process integration with its customers at a cost less than $\$ 1$ Million to improve the attribute 4 , it would be an investment worth making. The interrelation of these performance attributes to enhance the agility of the supply chain would lead to new opportunities for decision-making. For instance, these opportunities could be found by finding the relationship between percentage of times clients additional requests for service has been accommodated (att-8) and percentage of contract renewals (att7); percentage of virtual meetings (att-2) and percentage of correct order fulfillments (att-4); similarly finding the interrelations with various attributes would help in improving the agility in supply chains.

\section{Conclusion}

This paper has attempted to discuss the need for the companies to move from traditional supply chain management to agile supply chain management leveraging the latest trends in the information technology. Further the paper attempted to present performance metrics to measure the agility in the supply chains. Companies like Cisco, Dell Computers, etc have successfully implemented various measures to make their supply chains agile. With the help of excellent process integration $50 \%$ of Cisco's customers orders are fulfilled by its manufacturing partners. However, Cisco has complete visibility and control of their manufacturers. The company has also decreased its time to volume by three months and thereby increasing revenues by $\$ 100$ million annually. XYZ Trucking Company has also taken measures to make its supply chain agile and benefited monetarily as well as in terms of enhanced service delivery. 


\section{References}

Anderson, David L. and Dr. Hau Lee, "Synchronized Supply Chains: The New Frontier", http://anderson. ascet. com, 1999.

Anderson, David L. and Dr. Hau Lee, "The Internet-Enabled Supply Chain: From the 'First Click' to the last Mile", http://Ascet. com.

Bowersox, DJ and Closs, DJ (1996) Logistical Management-The Integrated Supply Chain Process, McGraw-Hil New York. Page 18 Journal of Business and Behavioral Sciences 18

Christopher, Martin, "Creating the Agile Supply Chain", http://christopher. ascet. com.

Cross, Gray J., "How e-business is transforming supply chain management”, Journal of Business Strategy 21 (2): 36-39, March/April 2000.

Domocker, Judy, “Business seeks to cut weak links from supply chains”, Information Week (776): 141-146, March 06, 2000.

Ganeshan, Ram, "An Introduction to Supply Chain Management", http://silmaril. smeal. psu. edu/misc/supplychain-intro. html, 1999.

James, Dana, "E-commerce looms large on the horizon" , Marketing News 33 (18): 3, August 30, 1999.

Jay, Bal, Richard Wilding \& John Gundry, "Virtual teaming in the agile supply chain", International Journal of logistics Management 10 (2): 71-82, 2000.

Khurrum S Bhutta, Faizul Huq “Merging ECR and Consumer Centric Marketing”, working paper at Department of Management sciences, University of Texas at Arlington, 2000.

Messmer, Ellen, "Supply chain software meets Web-based e-commerce", Network World 17 (18): 52, May 01 , 2000.

Rachel Mason-Jones, Ben Naylor and Denis R. Towill "Engineering the Leagile Supply Chain" International Journal of Agile Management Systems, 2000.

Turban, Efraim, Jae Lee \& David King, Electronic Commerce: A Managerial Perspective, Prentice Hall Inc.(New Jersey) 2000.

Siverts, Barbara, "Cisco‘s Extended Enterprise Delivers Competitive Advantage", http://siverts. ascet. com. 


\section{E-Commerce Sourcing Models}

By Anne Nelson

ESCPau, France 


\section{Abstract}

Electronic commerce (EC) involves business transactions, marketing efforts, information gathering, and other functional activities with respect to information technology (IT) both within and without an organization. It provides various opportunities to a firm to adopt different business sourcing models and allows new opportunities to configure organizational structure for both private and public companies within the New Economy. Critical factors for EC success dictate that the firm must re-evaluate its business sourcing model from with complexity theory and the New Economy, thereby emphasizing the need for the firm to effectively coordinate its EC initiatives and consider all sourcing opportunities in this nonlinear, decentralized, alliance-focused, and CRM-based environment. This research will build from 1) an understanding of EC, to 2) the complex systems of EC in the New Economy, to 3) the sourcing mode used in the EC business model.

Keywords: Electronic commerce, outsourcing, sourcing models, complexity theory

Electronic commerce (EC) literature suggests that the complementary technologies of the World Wide Web and the relational database management system (RDBMS) have been integrated to build EC. Integrated, these technologies are known as Web database constructions. It is the scalability and flexibility of Web database construction technology and the client/server foundation on which it is based that have enabled the colossal growth of EC. The literature is ripe with examples of how EC has provided both the ways and the means for virtual stores and Web presence for an unlimited number of private businesses today. Prior to the emergence of these technologies, information technology (IT) was primarily used by businesses as supporting the elimination of extraneous costs and reducing expenses. Today, the new IT systems also help pubic organizations maximize shareholder wealth through cost savings, increased revenue, and customer service. 


\section{Complementarity Theory and the Collaborative Nature of IT}

This research is based is complementarity theory that supports the collaborative nature of IT. Complementarity theory is derived from economic theories and is most often used by the body of knowledge to develop a model linking a net value to the electronic system success. This theory provides a rational foundation for understanding the drivers of the value derived by the participants internal and external to the collaboration of EC, and for selecting design characteristics and subsequent sourcing modes in such a way that maximizes cost savings. In the context of EC design, an application of complementarity theory would suggest that when stakeholders in EC can provide a set of related or complementary features, it greatly enhances the benefit to the user while reducing his/her cost of effort and time spent in using the system, thereby maximizing the user's net value. Complementarity theory would also imply that having only a subset of complementary design features in isolation will not bring the desired benefits to the organization's stakeholders (Crafton, 2002).

Complementarity theory explains two main IT issues: (1) the efficient dissemination of information through the organization of information resources, search, and resource linking capabilities, and (2) the global forum for asynchronous and synchronous interactions involving customer relationship management (CRM) and knowledge management issues. Given the large number of design alternatives in an open environment, complementarity theory provides rationalization why certain features of a collaborative system must be provided in tandem to increase stakeholder benefits and reduce organizational opportunity cost. It also provides the theoretical premise to design and implement Web-based interactive electronic forums, i.e., EC.

Traditionally, management has viewed the organization as a mechanistic, linear system characterized by a simple and predictable cause and effect. However, another theory that supports the collaborative nature of EC and which is a complement to complementarity theory is complexity theory. This theory brings to management an organic, nonlinear, and holistic way of viewing organizational systems in the new information age, the New Economy. Hypothesized outcomes of this research also include a better understanding of the emergent behavior such as sourcing choices of the global networked systems within the EC model. One of the greatest challenges to organizations in the New Economy of EC may be to executives and senior management. "Both the Knowledge Era and the Network Society are reducing the capacity of control and increasing the requirement of distributed intelligence and accountability" (Merry, 1995). The move needed for EC is toward autonomy and self-organization and away from central direction and control with sourcing methodologies intrinsically linked to these moves. The adjustment in thinking and attitude and the resulting disintermediation is proving extremely difficult for many of the formal leaders. Traditional wisdom says an organization should have a CEO overseeing a management team with a vision or strategic intent supported by a shared culture. The organization and its management team should focus on its core competency, build on its strengths, adapt to its environment, and keep a close eye on the bottom line. Goal and strategy formation, environmental analysis, and strategic control are the hallmarks of a viable organization. Most may no longer be applicable from a complexity theory management perspective in the global economy. The traditional organization is seen as a clockwork machine following linear Newtonian rules. But complexity theory has shown the world does not operate this way. The world displays creative disorder (Lissack, 1996). For EC to succeed, global organization management, indeed management in general, today requires the ability to see systems as unpredictable and non-linear. Ralph Stacey (1993) noted two kinds of managers:

One: ordinary management is needed to fulfill day-to-day problem solving through a linear, analytic process;

two: extraordinary management is required for the organization to transform itself when in the midst of open-ended and rapid change.

Stacey (1993) added that rational decision-making may not work in the New Economy because the givens must be disputed. Extraordinary management requires the development and use of tacit knowledge within the organization, these necessary for the choice sound souring modes. 
EC managerial issues include finding solutions such as outsourcing to deal with growing complexity and uncertainty. The acceleration in the rate of change, hyper-competition, the crunch economy, the knowledge landscape, the changes in the workforce, all create problems for organizations and their networks, which are complex systems, in the process of changing themselves to better adapt to new environmental conditions. They are problems of how to ensure organizational sustainability in a complex, uncertain, interconnected world. They are multi-layered, nonlinear, interconnected, dynamic, complex problems with which the New Economy has difficulty dealing. Complexity theory helps management understand the uncertain environment and the irregular effects of nonlinearity and interdependence on organizational functioning in the global economy. It focuses attention on the different states in which the organization may be functioning. It explains why sometimes large efforts give no results and at other times a minor change, such as in sourcing mode, leads to a landslide.

\section{The Innovation Diffusion Process: the Birth of Outsourcing}

Organizations are influenced by the actions of their peers and competitors through innovation diffusion process (Rogers, 1995). The decision by Kodak, for example, to outsource its entire IT operations was considered a major event in the IT community that legitimized large-scale outsourcing of IT functions. Loh and Venkatraman (1992b) tested this hypothesis and suggested that there indeed was a "Kodak effect" in the IT outsourcing industry wherein internal influence became important in the sourcing decision after the Kodak announcement. However, Hu et al (1997) disputed these results based on an expanded data set and found that there was no such Kodak affecting the IT sourcing industry. Peer pressure in the context of EC was not just a matter of following trends; it rapidly became a matter of holding on to customers and impacted sourcing modes. In almost every industry, customers expected to find detailed product information at the click of a mouse and in many of these industries, large segments of customers moved their purchasing online for convenience. Therefore, any significant EC initiatives by competitors had to be quickly duplicated, firms often found themselves lacking the resources to do so, and sought outside help. Borders' partnership with Amazon.com is a case in point.

In one of the earliest of their many research articles on IT sourcing, Lacity and Hirschheim (1993) conducted exhaustive interviews with executives at 14 Fortune 500 companies and came to the conclusion that there was little that an outsourcing provider could do that an internal IT organization could not. However, this observation was based on an environment that was relatively stable and the principal factor to motivate outsourcing was the economies of scale that could be achieved by an outsourcer. In the case of EC, with both technologies and business processes in a state of flux, it is unlikely that EC initiatives would exhibit properties of production factors subject to economies of scale. Therefore, even very large firms frequently turned to new, boutique firms for assistance in implementing EC projects.

McFarlan and Nolan (1995) were among the first to point out the idiosyncrasies of IT outsourcing caused by the rapid advances in technology. Based on approximately a dozen detailed case studies of outsourcing decisions, McFarlan and Nolan pointed out that the motives of clients and vendors are antagonistic in many ways. Whereas clients expect vendors to provide the latest technologies, vendors try to extend the life of existing systems to maximize profits. In the IT domain, significant technological changes are often unforeseeable at the time of signing the contract, creating possibilities of litigation and dispute over providing support for such improvements. The researchers, therefore, suggested that IT outsourcing is attractive when the tasks are only of operational significance and for new application development, the presumption should be in-house development unless internal capabilities are lacking. In such cases, it is not worth dwelling on how the firm got to the point where internal capabilities were inferior, but rather, how to extricate itself from the situation. 
Teng et al (1995) used resource dependence theory, discussing where all firms are dependent in varying degrees on some elements in their environments, usually as a result of the control of these elements on some needed resources. Here the researchers suggested that firms should enter into outsourcing relationships when its internal IT operations fell short of expectations. They surveyed 188 senior executives responsible for IT outsourcing and found that perceived discrepancy in information quality and IT support quality were significantly related to the observed change in outsourcing behavior. IT cost effectiveness and the financial performance of the firm was not significant. Grover, Cheon, and Teng (1996) carried this research further to study the relationship between observed outsourcing and perceived success. They found that service quality, the visible deliverables and reliability of service, were a significant mediating variable for outsourcing success, particularly when the market for outsourcing become increasingly competitive. Another important mediating variable for outsourcing success was identified as partnership quality.

Lee and Kim (1999) also found evidence for the mediating role of partnership quality in a sample of 36 client organizations in Korea. Partnership quality was found to be strongly correlated with outsourcing success. Thus, fostering a co-operative relationship based on trust, communication, business understanding, benefit and risk share, and commitment is critical to get the greatest benefit from outsourcing.

Though other determinants of outsourcing such as "competence gaps" were beginning to emerge in the literature in the mid 1990's, the idea that cost savings were the major determinant of outsourcing continued to be popular. Lacity, Willcocks, and Feeny (1996) interviewed managers associated with 62 outsourcing decisions in 40 firms between 1991 and 1994 using cost savings as the measure for the success of an outsourcing relationship. They found that most "total outsourcing" decisions where outsourcing firms handle more than 80 percent of the IT budget, experienced significant problems due to illdefined "relational" contracts, or organizational alliances, and inflexibility to business and technological changes. Firms with total insourcing experienced problems, too.

Since the beginning of the 90's, customer loyalty has become the key word of companies. Putting the customer at the center of the company and at the center of strategy is the essence of CRM (Customer Relationship Management) (Dyché, 2001). The expansion of Internet, access to information, visibility, and offer comparisons have changed the rules and the customers are now the drivers of the economy (Crafton, 2002). Customers want more services, better prices, high quality, and quick delivery (Crosby, 2002). Furthermore they want to interact in total freedom through the media they choose (Barge \& Poupee, 2002). They ask for personalization and want to be recognized individually. Companies have all the technology in-hand necessary to satisfy customers' needs, but it is a real challenge (Kalustian, 2002). The business world is changing even as the information age evolves (O'Conner, 2002). CRM evolves to electronic-CRM (e-CRM) and now mobile-CRM (m-CRM) (Pargman, 2000). Firms must integrate all the processes and technology required to provide its products and services to customers through multiple channels in a simple, efficient, and comprehensive way. In this connected world, companies have to find simple rules and strategies that will help them to construct solid, long-term relationships with their customers. Management needs to explore sourcing modes that lead their firms toward alliances with loyal customers in order to survive and grow. Wireless technology is perhaps no longer a choice for companies in the New Economy (Rheingold, 1993). There are many challenges involved in building m-CRM sourcing strategies (Pang, 2002. Many experts place m-CRM as the strategy leader for organizations and their sourcing modes in the near future. 


\subsection{Electronic Commerce Sourcing Initiatives}

DiRomualdo and Gurbaxani (1996) identified a rigorous classification scheme to examine the impact of the business potential of EC initiatives on the sourcing mode chosen by firms. Sanders, Gebelt, and Hu (1997) provided empirical support for the importance of motives other than cost in the sourcing decision. Based on a survey of individuals in 34 companies that had entered outsourcing arrangements between 1988 and 1993 and whose contracts were more than two years old, it was found that technologi$\mathrm{cal}$ and strategic reasons were the strongest motivations for outsourcing. The role of cost savings was not very clear. Corroborating the suggestions of Lacity et al. (1996), they found that a tight contract was an important ingredient for outsourcing success and contrary to expectations, outsourcing was more successful in companies that viewed IT as a core function and failures were more prevalent when IT was considered a commodity. Partnerships were also generally more successful than mere supplier relationships.

Using financial data, Smith, Mitra, and Narasimhan (1998) tried to identify the motives of 29 firms that entered large-scale outsourcing relationship between 1988 and 1994. Using non-parametric tests, they found that firms that outsourced had significantly lower overhead costs, lower cash reserves and higher debt before the outsourcing event. They also had increased long-term debt, declining growth rates and increasing financial leverage prior to the event. Since there was no significant trend in these firms to focus on core competencies, they argued that firms entered into outsourcing arrangements primarily to reduce costs and to generate cash. In the context of the banking industry, Ang and Straub (1998) found that production costs economies and transaction cost economies were influential in IT outsourcing decisions and smaller banks were more likely to outsource than larger banks.

The literature on IT sourcing focuses on cost savings. From the point of view of cost savings and overall satisfaction, researchers have been consistent in recommending against outsourcing when technologies are immature and/or unfamiliar either because the client has insufficient knowledge to write the terms of a contract (Lacity et al., 1996; Sauders et al., 1997) or because outsourcing diminishes the knowledge gained or the learning opportunity. However, contrary to these suggestions, recent research suggests that some of the most commonly outsourced IT functions are Internet services, where technologies are changing rapidly, making it difficult to write tight contracts, and one of the strongest motivations for the use of outside help is to gain outside expertise (Lackow, 2001). In addition, EC offers a fertile context to examine the influence of co-ordination costs because EC involves alliances between many stakeholders within and without the firm (Brynjolfsson, 1994; Malone \& Crowston, 1994; Staub \& Watson, 2001; Ven \& Delbecq, 1976). The expansion of EC , during the period of 1997 to 2002, is expected to significantly influence IT sourcing decisions. Apart from the differences between traditional IT projects and EC projects outlined earlier, the commercial use of Internet technologies was new to both IT firms and the traditional "brick-and-mortar" firms during this period (Earl, 1996). There were rapid changes in organizational models (such as advertising versus subscriptions versus revenue sharing models) and technology platforms (such as open source versus proprietary). Whereas IT firms had the opportunity to leverage their technical knowledge among multiple clients, traditional non-IT brick-and-mortar firms had the opportunity to create profit centers by combining technical knowledge with their business knowledge. Therefore, the literature leads to an examination of the influences of various factors on the sourcing decisions for EC systems. 
One of the primary drivers for IT outsourcing identified in prior research is an attempt to reduce costs. For example, Lacity and Willcocks (1998) found that over 80 percent of their respondents cited cost savings as a reason for IT outsourcing and expectations of cost savings continue to find importance in recent practitioner literature (Dash, 2001). IT cost savings to the extent of 15 to 20 percent were cited in the banking industry as a result of outsourcing (Ang \& Cummings, 1997). Outsourcers are expected to achieve these cost savings because of factors such as the adoption of superior management practices and economies of scale in training and development (DiRomualdo \& Gurbaxani, 1998) and competitive pressures of the marketplace (Saarinen \& Vepsalainen, 1994). These savings can be a significant driver for EC outsourcing because "cost savings" has been suggested as one of the principal ways by which firms can attain competitive advantage (Porter, 1998).

Following the basic profit-maximizing hypothesis to managing projects it would be suggested that all else being equal, firms compare different development modes and choose the lowest cost mode when they decide whether to make or buy (Ang \& Straub, 1998; Tirole, 1988). Firms would therefore choose outsourcing when outsourcing is expected to be less expensive and insourcing when insourcing is expected to lower development costs for electronic systems.

\subsection{Prior Experience and Sourcing Modes}

Firms with prior outsourcing experience are likely to have better information about the elements of outsourcing contracts that may help them identify avenues for future cost savings. They are also likely to have better negotiation, contracting, and monitoring skills, and are therefore likely to save more as their experience with IT outsourcing increases (Mahoney, 1992).

These prior experiences can translate into current expectations. Research in managerial decision-making suggests that decision-making situations are framed by managers in terms of familiar contexts gained from prior experience to give meaning to current observations (Beach, 1997). These frames have been found to significantly influence current decisions (Beach, 1997; Kahneman \& Tversky, 1979). Since prior IT outsourcing experience is expected to lead to success in achieving cost savings from outsourcing and EC initiatives are generally led by the IT groups in companies, past outsourcing experiences are likely to be projected into the present through the non-linear decision-framing process to influence expectations of cost savings from outsourcing EC development. 


\section{IT Outsourcing Experience May Impact the Extent of Cost Savings Expected}

Research suggests that prior outsourcing experience is likely to have additional second-order effects on the relationship between IT cost savings expectations and the sourcing mode apart form direct influence on expected cost savings. This comes from a systematic complementary influence of prior outsourcing relationships on current decision-making behavior of managers. The concept of risk associated with an IT project was explored in detail by Keil, Tan, Wei, Saarinen, Tuunainen, and Wassenaar (2002). They defined risk as a non-zero probability that some undesirable outcomes will occur. Based on the definition and complementary theory, a decision is considered risky if its outcome is uncertain and may result in a loss. Considering the decision to continue a software project as a risky decision, they found evidence for a relationship between risk propensity and risk perception and also for the moderating influence of uncertainty avoidance in national cultures on the relationship. Given that outsourcing is a risky endeavor (Earl, 1996), the influence of prior outsourcing relationships on risk taking is expected to influence outsourcing behavior. The literature suggests this will occur in two ways: the impact of prior outcomes and problem domain familiarity (Sitkin \& Pablo, 1992).

Prior research on risk behavior suggests that outcome history influences risk behavior through its impact on two individual factors: risk propensity and risk perception (Sitkin \& Pablo, 1992; Sitkin \& Weingart, 1995). Risk propensity is defined as an individual's current tendency to take or avoid risks. Risk perception is defined as an individual's assessment of how risky a situation is in terms of probabilistic estimates of the degree of situational uncertainty, how controllable that uncertainty is and confidence in those estimates (Sitkin \& Weingart, 1995). The influence of risk propensity on decision-making is that it affects the relative salience of threat or opportunity in a situation and thus leads to biased risk perceptions. When individuals have high risk-propensity, they weigh potentially negative outcomes more heavily than positive outcomes and thereby overestimate the probability of loss relative to the probability of gain. Individuals with low risk-propensity do just the opposite. Though prior research considered risk propensity as a stable dispositional attribute, current research conceptualizes it as an individual trait that can change over time and is thus an emergent property of the non-linear decision-making process. Sitkin and Weingart (1995) and other complexity theorists have suggested that this conceptualization can account for the important role of past experience and the capacity of people to adapt - as complex adaptive systems - while simultaneously suggesting that as individual gain more experience, they may be less susceptible to contextual influences and more likely to exhibit cross-situational consistency.

Sitkin and Weingart (1995) also found that successful outcome histories influence behavior in risky situations in two ways: (1) influencing how much decision makers lean a priori toward taking risks (direct influence on risk propensity) and (2) by influencing what kinds of information they attend to (effect on risk perception). In the context of the EC sourcing decision, as managers complete increasing numbers of IT projects through outsourcing, they are likely to modify their overall mental representation (knowledge management) of how well they have managed outsourcing relationships and achieved cost savings in the past. These prior successes from outsourcing would increase a manager's propensity to take risks and in turn direct attention to low-risk aspects of the decision and lead managers to overestimate their ability to derive benefits from outsourcing.

In addition to the influence of prior outcomes, experts suggest that an individual's familiarity with a problem domain as a result of increased levels of past experience can affect risk perceptions independently of the resulting outcomes (Sitkin \& Pablo, 1992). With increased experience, decision makers are more likely to focus on their own abilities and past successes rather than on current situational constraints. They may therefore simultaneously underestimate the actual risks involved and overestimate their ability to overcome unforeseen problems.

Both of the above effects suggest that under similar conditions for expected cost savings, as managers' past experience with IT outsourcing increases, they would increasingly tend toward outsourcing while deciding upon the sourcing mode for EC systems. Prior outsourcing experience is thus expected to show a moderating effect on the relationship between IT cost savings expected and the sourcing mode (Baron \& Kenny, 1986; Venkatraman, 1989.) 


\section{Methodology for Re-Evaluation}

A logistic regression and content analysis was used as methodology for re-evaluation of the sourcing model. The "observed sourcing decision" of the managers was used as the dependent variable. Information regarding EC initiatives was obtained from the Factiva database. Factiva and the Dow Jones Interactive database merged as of April 2003. Factiva is a searchable full-text database of nearly 8,000 newswires, newspapers, magazines and trade journals. It also has comparative data on companies and industries and company SEC filings. Since EC initiatives are typically announced publicly in reasonable detail through the business press, information regarding such initiatives was collected using a full-text search of announcements made by companies. The period of 2001-2002 was used. The content analysis scheme was used to classify the announcements. The coding was done with the help of the content analysis software, Nvivo 2.0 Educational package. Nvivo is a software program for professional support and training for qualitative research. It allows for data analysis and enables quick coding of the announcements and easy retrieval once a coding scheme has been defined. It also facilitates quick search of documents and easy ad hoc creation of coding schemes. The software also enables quick recovery of sections in the project that have been coded for specific variables.

\begin{tabular}{lll}
\hline Hypothesis Number & Hypothesis & Literature's principal citations \\
\hline $\mathrm{H} 1$ & $\begin{array}{l}\text { The business' sourcing mode will } \\
\text { tend toward outsourcing as the } \\
\text { extent of cost savings expected } \\
\text { from outsourcings increases. }\end{array}$ & Ang \& Straugh, 1998 \\
& $\begin{array}{l}\text { Prior IT outsourcing experience will } \\
\text { positively influence the extent of } \\
\text { IT cost savings expected }\end{array}$ & Beach, 1997; Lacity \& Willcocks, 1998 \\
\hline $\mathrm{H} 2$ & The client's prior IT outsourcing & \\
& experience will moderate the & \\
& relationship between IT cost savings & \\
& expected and the sourcing mode. & \\
& As prior experience increases, the & \\
& sourcing mode tends toward outsourcing. & Keil, 2000; Sitkin \& Weingart, 1995 \\
\hline
\end{tabular}

Table 1: Research hypotheses for sourcing mode choice in EC non linear systems

\begin{tabular}{lll}
\hline Variable Name & Type & Definition \\
\hline $\begin{array}{l}\text { Observed sourcing } \\
\text { decision }\end{array}$ & Dependent Variable & $\begin{array}{l}\text { Completed external partnerships } \\
\text { for IT functions in the past }\end{array}$ \\
\hline Relationship structure & Independent Variable & $\begin{array}{l}\text { Joint venture, minority equity stake, } \\
\text { or contractual relationship }\end{array}$ \\
\hline Cost savings & Independent Variable & $\begin{array}{l}\text { Expectations to reduce IT costs } \\
\text { through outsourcing }\end{array}$ \\
\hline IT business potential & Independent Variable & $\begin{array}{l}\text { Expectation that the activity will help } \\
\text { in the discovery of new IT based business } \\
\text { applications for the future }\end{array}$ \\
\hline
\end{tabular}

Table 2: Explanation of the Variables to be Studied 
Since EC initiatives were a significant event for firms during the period studied, they were typically announced publicly in reasonable detail through the business press. One noted asset in information retrieval and data collect was the researchers' backgrounds as Publishers and Editors of U.S. newspapers. Information regarding such initiatives was collected using a full text search of announcements made by companies for the proposed period of 2001-2002 in the two leading newswires: PRNewswire and BusinessWire. These newswires provided comprehensive coverage of public announcements by firms, were available on Factiva's database, and have been used in prior IT research (Subramani \& Walden, 1999). Relevant announcements were retrieved using a search string to match words in announcements of interest. The goal, while selecting the search string, was to maximize the collection of relevant announcements while screening out irrelevant announcements. After examining a number of candidate announcements, the following search string was used and the resulting announcements were scanned to add relevant announcements to the Nvivo database:

(co $=<$ list of companies $>$ ) and ((dns=internet) or (key=EC )) and wc $>300$ ) and (Ip=e-commerce or EC or e-business or e commerce or (online near1 business) or (online near1 sales))

This string of code looks for announcements in the database that feature companies provided in the list following the keyword "co". The keywords "dns" and "key" denote the news category descriptor and keywords respectively and will be used to restrict the search to those announcements that related to the Internet or Electronic Commerce. This eliminated announcements made by companies that were not directly related to EC activities. "Wc" denoted word count and a minimum limit of 300 words was used because many announcements were only for information purposes, where the press was informed about certain activities without providing any relevant details. By eliminating announcements with small word counts, these researchers were able to focus attention on announcements that were more likely to have information of interest. The final keyword "Ip" denoted lead paragraph and was used to narrow the announcements to those where some EC activity was mentioned in the lead paragraph. This eliminated announcements where EC was mentioned in passing but was not the focus of the announcement.

These researchers hypothesized from years spent as a newspaper owners and publishers that there would be significantly more information available for larger, publicly traded firms than for smaller firms. Therefore, to be consistent in the study, these researchers used the list of the Standard and Poor's (S\&P) 500 firms as the basis for search. For over 140 years, the S\&P has been the pre-eminent global provider of independent, widely recognized investment data, valuation, analysis, and opinions. S\&P sets the standard as the globally pre-eminent provider of independent, widely recognized investment data, valuation, and opinions. The S\&P 500 Index consists of 500 stocks chosen for market size, liquidity, and industry group representation and is one of the most widely used benchmarks of U.S. equity performance. Since the guiding principle for inclusion in the S\&P 500 index is "leading companies in leading industries", the companies in this group were typically large firms and their performance significantly affected their own industries, in particular, and the overall economy, in general. Though the search results occasionally yielded announcements by firms outside the S\&P 500, the vast majority of the announcements used in the research were related to initiatives by firms in the S\&P 500 .

The researchers found that some of the announcements needed to be discarded since they were not useful for the study. Examples included topics on the setting up of Web sites with no clear commercial intent such as informational Web sites and content management arrangements. Similarly, these researchers also were aware that announcements regarding partnerships between two or more software firms to develop new software services to help clients leverage the Internet also did not contribute to the research and were discarded. 
Data for a variable used in this research was obtained by examining past announcements made by client firms. The variable was "prior IT outsourcing" contracts. The search string used to collect this data item is shown below:

( $\mathrm{co}=\mathrm{ABS}$ ) and (Ip=outsourc $\$ 4$ or contract $\$ 3$ or parner $\$ 4$ or engage $\$ 4$ ) and (Ip=IT or IT or (information $w / 1$ (system $\$ 1$ or technolog $\$ 4)$ ))

A wildcard search is made possible by the $\$$ sign in the search string. If there is uncertainty in the search, for example, on how to spell a word, wildcards can be very useful to the researcher. The are also often used to concatenate words or when researchers might want to investigate a variation of a word. The two most commonly used wildcards include: 1 ) the question mark (used to symbolize a single alphanumeric character in a search; 2) the asterisk (used to symbolize zero or more alphanumeric characters. The literature suggests that researchers avoid the asterisk as the first character in a search string because this may retrieve every record from the database (Staub, 2001). In the code above, contract $\$ 3$ will match terms with up to three letters beyond "contract" such as contract, contracts, contracted, and contracting. Operators are also used in the suggested coding scheme to combine search terms to identify a concept in the announcements documents. The two most commonly used operators are "AND" and "OR".

\section{Content Analysis}

Content analysis was used in the research. This is a research technique was chosen for the systematic, quantitative, and objective description of the manifest content of communication. Content analysis is widely used in management research (Jauch et al, 1980; Krippendorf, 1980; Maritan, 2001) and is a research tool often used to establish the presence of concepts or certain words within texts. These texts in a single study may also represent a several different types of incidences, such as Palmquist's 1990 study of two composition classes, in which he analyzed classroom discussions and lectures, teacher and student interviews, out-of-class interaction sheets, and writing journals. When conducting a content analysis, the text is coded or broken down into manageable categories; these may be word, word sense, phrase, sentence, or theme. These will studied using one of content analysis' basic methods, i.e., relational or conceptual analysis.

Content analysis has historically been a time consuming process for researchers. It was often performed manually, and then later on mainframe computers, which were slow, and were used to analyze data cards that had been themselves manually punched in by human coders. Often just single studies employed thousands of these cards. Time constraints and human error and made this method impractical for large texts though it was an often utilized research method up until the 1950's. In early content analyses the studies were limited to an observation of the frequency of the occurrence of identified terms (word counts. Researchers began investigating need for more sophisticated methods of analysis by the mid1950 's focusing on concepts rather than simply words, and on semantic relationships rather than just presence (de Sola Pool, 1959). While both traditions still continue today, content analysis now most often used to explore mental models, and their affective, linguistic, social, cognitive, historical, and cultural significance. These mental models are simply a network or group of interrelated concepts that demonstrate subconscious or conscious perceptions of reality. These internal mental networks of meaning are constructed as inferences are drawn and information gathered. 


\section{Conceptual Analysis}

Traditionally, content analysis has most often been thought of in terms of conceptual analysis. In conceptual analysis, a concept is chosen for examination, and the analysis involves quantifying and tallying its presence. This type of content analysis is also known as thematic analysis. However, this term is somewhat problematic, given its varied definitions in current literature (Palmquist, Carley, \& Dale, 1997; Smith, 1992). With conceptual analysis, the focus is on the researcher looking at the occurrence of selected terms within a text or texts, although the terms may be implicit as well as explicit. While explicit terms obviously are easy to identify, coding for implicit terms and deciding their level of implication is complicated by the need to base judgments on a somewhat subjective system. To attempt to limit the subjectivity, (as well as to limit problems of reliability and validity), coding such implicit terms usually involves the use of either a specialized dictionary or contextual translation rules.

Conceptual analysis begins with identifying research questions and choosing a sample or samples. Once chosen, the text must be coded into manageable content categories. The process of coding is basically one of selective reduction. This is central idea of content analysis. Text is reduced to categories consisting of a word, set of words or phrases, on which the researchers can focus. Specific words or patterns are indicative of the research question and determine levels of analysis and generalization.

By reducing the text to categories consisting of a word, set of words or phrases, the researchers can focus on, and code for, specific words or patterns that are indicative of the research question.

Once the research question has been established, the researchers must make his/her coding choices with respect to the eight category coding steps indicated by Carley (1992). These steps include: Decide the level of analysis: Decide how many concepts to code for; Decide whether to code for existence or frequency of a concept; Decide on how you will distinguish among concepts; Develop rules for coding your texts; Decide what to do with "irrelevant" information; Code the texts; Analyze your results.

\section{Issues of Reliability \& Validity}

The issues of reliability and validity are concurrent with those addressed in other research methods. The reliability of a content analysis study refers to its stability, or the tendency for coders to consistently recode the same data in the same way over a period of time; reproducibility, or the tendency for a group of coders to classify categories membership in the same way; and accuracy, or the extent to which the classification of a text corresponds to a standard or norm statistically. Gottschalk (1995) points out that the issue of reliability may be further complicated by the inescapably human nature of researchers. For this reason, he suggests that coding errors can only be minimized, and not eliminated. He suggests 80 percent as an acceptable margin for reliability.

The validity of a content analysis study refers to the correspondence of the categories to the conclusions, and the generalizability of results to a theory.

The validity of categories in implicit concept analysis, in particular, is achieved by utilizing more than one classifier to arrive at an agreed upon definition of the category. 


\section{Content Analysis and IT Research}

Content analysis is also beginning to be used in IT research. For example in a recent study, content analysis was used in the analysis of interview transcripts at eight firms to examine how three contingency forces (corporate governance, economies of scope, and absorptive capacity influenced the mode of IT governance (Sambamurthy \& Zmud, 1999).

Following the steps recommend for content analysis (Krippendorf, 1980; Meindl, Ehrlich, \& Dukerich, 1985) this research used prior empirical and theoretical research to create the classification scheme described below to categorize the dependent (observed sourcing mode decision) and independent variables.

\begin{tabular}{|c|c|c|c|c|}
\hline Construct and citation & Construct definition & Procedural definition & Variable and citation & Measurement \\
\hline $\begin{array}{l}\text { Sourcing mode } \\
\text { (Gulati \& Singh, } \\
\text { 1998; Nam et al, } \\
\text { 1996) }\end{array}$ & $\begin{array}{l}\text { Extent to which } \\
\text { contractual relations } \\
\text { substitute for } \\
\text { hierarchical controls }\end{array}$ & $\begin{array}{l}\text { The substitution } \\
\text { of contracts for } \\
\text { hierarchicalcontrols } \\
\text { implementing the } \\
\text { system }\end{array}$ & $\begin{array}{l}\text { Relationship structure } \\
\text { (Gulati \& Singh, 1998; } \\
\text { Nam et al., 1996) }\end{array}$ & $\begin{array}{l}\text { Internal responsibility: } 0 \\
\text { Joint venture: } 1 \\
\text { Minority equity stake: } 2 \\
\text { Contractual } \\
\text { relationship: } 3\end{array}$ \\
\hline $\begin{array}{l}\text { IT cost savings } \\
\text { expected from } \\
\text { outsourcing } \\
\text { (Lacity \& Willcocks, } \\
\text { 1998) }\end{array}$ & $\begin{array}{l}\text { Expectation to reduce } \\
\text { IT costs through } \\
\text { outsourcing }\end{array}$ & $\begin{array}{l}\text { Code in increasing } \\
\text { order of clients' } \\
\text { expectations of } \\
\text { cos savings from } \\
\text { outsourcing }\end{array}$ & $\begin{array}{l}\text { Cost savings } \\
\text { (Lacity \& Willcocks, } \\
1998 \text { ) }\end{array}$ & $\begin{array}{l}\text { 0: internal } \\
\text { department } \\
\text { and cheaper } \\
1: \text { Internal and external } \\
\text { organizations are } \\
\text { competitive } \\
2: \text { External organization } \\
\text { is cheaper } \\
3: \text { External organization } \\
\text { is substantially cheaper }\end{array}$ \\
\hline $\begin{array}{l}\text { Outsourcing } \\
\text { experience }\end{array}$ & $\begin{array}{l}\text { Organization's } \\
\text { experience with } \\
\text { outsourcing IT } \\
\text { functions }\end{array}$ & $\begin{array}{l}\text { The number of } \\
\text { completed external IT } \\
\text { partnerships by the } \\
\text { firm in the past } 5 \text { years }\end{array}$ & $\begin{array}{l}\text { Projects_completed } \\
\text { (Nam et al, 1996) }\end{array}$ & $\begin{array}{l}\text { Number of completed } \\
\text { external partnerships } \\
\text { for IT functions } \\
\text { in the past }\end{array}$ \\
\hline $\begin{array}{l}\text { IT Business potential } \\
\text { (DiRomualdo \& } \\
\text { Gurbaxani, 1998) }\end{array}$ & $\begin{array}{l}\text { Expectation that the } \\
\text { activity will help in } \\
\text { the discovery of new } \\
\text { IT based business } \\
\text { applications in the } \\
\text { future }\end{array}$ & $\begin{array}{l}\text { Code based on the } \\
\text { influence of the activity } \\
\text { in helping the discovery } \\
\text { of new ways to exploit } \\
\text { IT in business in } \\
\text { the future }\end{array}$ & $\begin{array}{l}\text { Business_focus } \\
\text { (Clemons \& Row, } \\
\text { 1991; } \\
\text { DiRomualdo \& } \\
\text { Gurbaxani, 1998) }\end{array}$ & $\begin{array}{l}\text { 0: IT improvement } \\
\text { 1: Improve cost or } \\
\text { quality of existing } \\
\text { service } \\
\text { 2: Create new } \\
\text { product or service }\end{array}$ \\
\hline
\end{tabular}

Table 3: From the Literature: Construct, Citation, and Variable Measurement

The sourcing announcement was the unit of analysis in this research. Announcements were coded using the scheme and steps were taken to ensure the reliability of the coding. The content analysis scheme is summarized in Table 3. 


\subsection{Sourcing Mode}

Prior research has typically classified governance structures as hierarchical (internal) or contractual based on the extent of equity ownership of one firm in another. Partnerships with greater extent of equity ownership by one firm are considered more hierarchical than those without because equity ownership simplifies the distribution of surplus and creates legal reporting requirements (Gulati \& Singh, 1998). However, there are a number of elements associated with internal controls that may not be adequately captured by the extent of equity controls. These elements include: 1) command structure, 2) incentive systems to link rewards to performance, 3) standard operating procedures that allow quick decisions, 4) dispute resolution procedures that specify a hierarchy of entities of appeal, and 5) non-market pricing systems that help specify compensation when specifications are changed (Stinchcombe, 1985).

To capture the systematic differences in hierarchical controls between different governance structures, this research defined the variable relationship structure by building upon the typology introduced by Gulati et al. (1998) in their study of alliances. Following that study and prior MIT research, in decreasing order of hierarchy are Internal IT organizations, joint ventures, minority equity ownership, and contractual relations. These structures differ in their mechanisms for collecting and disseminating information to guide interdependent actions and resolve conflicts (Galbraith, 1977; Nam, Rajagopalan, Rao, \& Chaudhury, 1966; Saarinen \& Vepsalainen, 1994).

At the hierarchical end of the spectrum, internal IT organizations have an established hierarchy of managers to coordinate activities and resolve disputes between the department and the organization. Following Lacity and Willcocks (1998), vendor buy-in contracts, where vendors supply skilled personnel who work under the supervision of internal managers were also included in this category. In joint ventures, when the partners create a separate entity with ownership distributed among the partners, a separate hierarchy of managers oversees day-to-day operations and address problems as they arise. Dispute resolution procedures are also generally included among the standard operating procedures in joint ventures. Minority ownership relations were one where set of partners takes minority ownership of another partner without creating a separate organization and has less hierarchical controls than joint ventures. Supervision is typically in the form of board membership for investing partners in the invested firm. Though these members are not involved in day-to-day operations of the firm, their presence on the board helps share information, ratify decision, and can help resolve conflicts as they arise. Contractual arrangements are closest to arms-length market exchanges and do not involve any shared ownership or administrative structures. Members of partner firms work from within their own organizations. None of the elements of a hierarchical relationship are necessarily part of the arrangement and new decisions are negotiated between partners. Such arrangements include licensing, second-sourcing, joint contracts and technology exchange agreements.

The dependent variable relationship structure measured the extent of substitution by the market and is coded in decreasing order of hierarchical controls with internal IT organizations coded 0 , joint ventures coded 1 , minority investments coded 2 , and contractual arrangements coded 3. 
The cost savings expected from outsourcing was coded in a straightforward manner in the variable cost savings in increasing order of expected cost savings as perceived by the client organization. When the internal organization was believed to be cheaper than any known IT vendors, cost savings was coded 0; when internal and external vendors were believed to be competitive with each other, cost savings was coded 1; when vendors were expected to save costs compared to internal IS, cost savings were 2; and when clients were superlative in their opinion of cost savings from outsourcing, through expressions such as "significant cost savings expected" or "substantial cost savings expected", cost savings was coded 3. When no information was available, the variable was coded as unknown.

\subsection{Prior IT Outsourcing Experience}

Prior IT outsourcing experience was measured by the variable projects completed. This was based on the idea that firms learn about the outsourcing process through a "learning-by-doing" process. To collect data for this variable, the researchers first ran an exhaustive search on PRNewswire and BusienssWire for all announcements made by the subject identified all completed IT projects in the period, for which the firm used the assistance of external partners. Unlike data collected solely from publications such as ComputerWorld or InformationWeek, it was hypothesized by the researchers that collecting data from the two newswires would provide a comprehensive collection of all significant projects. Though this procedure did not guarantee that all outsourcing arrangements were captured, they were a best attempt at performing a comprehensive search and were consistent with procedures in earlier research for comprehensive historical search (Gulati, 1995).

\subsection{IT Business Innovation Potential}

Based on a review of the IT literature for the various ways in which IT innovations generate business value, the following focus areas were identified in prior research: 1) support or improve e firm management; 2) decrease costs of existing goods or services; 3 ) improve their quality; 4) create new products or services for which there is sufficient demand (Clemons \& Row, 1991; DiRomualdo \& Gurbaxani, 1998).

These were coded into the variable market focus as follows: when the EC initiative focuses on improving or supporting general firm administration with no emphasis on its impact on the products and services sold by the firm, market focus was coded 0 . When the focus is on decreasing the costs of existing goods and services or improving their quality as perceived by customers, market focus was coded 1 . This included measures such as setting up a Web site to sell products or services to an expanded market because the main consequences of such an initiative may be interpreted as reducing the cost of selling goods to the new market. When the initiative was aimed at creating new IT based products or services, market focuse was coded as 2 . 


\section{Results}

The hypotheses were testing using a multinomial logistic regression model to examine the effects of the independent variables on the dependent variable. The size of the firm was used as a control variable following prior IT research on outsourcing (Ang \& Straub, 1998). This variable was operationalized as the natural logarithm of capitalization and data was obtained from the Center for Research in Securities Prices (CRSP) database. Academic researchers recognize the CRSP database as one of the most comprehensive, complete, and accurate historical data files on the market. The CRSP files cover securities listed on the NYSE, AMEX and Nasdaq Stock Markets, US Government Treasury issues, and US Mutual Funds.

CRSP first sorts all stocks on the NYSE by market cap and breaks the universe into ten equal groups by number of names. These are called "deciles". Decile 1 is the group of the largest stocks on the NYSE and decile 10 is the group of the smallest stocks on the NYSE. CRSP then includes all equivalently sized AMEX and NASDAQ (OTC) stocks into the NYSE size decile in which they fit by market cap. All Small Cap Indexes are rebalanced quarterly. There are three ranges of indexes: CRSP 9-10 Index: The smallest fifth of NYSE stocks by name and all equivalents from other exchanges. This index is sometimes referred to as "micro-cap" stocks. The CRSP 6-10 Index is the smallest half of NYSE stocks by name and all equivalents from other exchanges. This index is sometimes referred to as "Iow-cap" or "small-cap" stocks and is similar in size to Russell 2000 Index. The CRSP 6-7-8 Index includes Deciles 6, 7 and 8 of NYSE stocks and all equivalents from other exchanges.

The general specification of the multinomial logistic regression used in the research was:

$$
\operatorname{In}\left(\mathrm{P}_{\mathrm{ij}} / \mathrm{PO}_{\mathrm{j}}\right)=\mathrm{a}+\mathrm{b}_{\mathrm{i}} \mathrm{X}_{\mathrm{j}}
$$

Where $\mathrm{Pij}$ is the probability of the $\mathrm{i}^{\text {th }}$ event occurring for the $\mathrm{j}^{\text {th }}$ case. The three possible events are a joint venture ( $i=1)$, minority equity partnership ( $i=2)$ and fee for service contracts ( $i=3)$. P0 is the probability of internal development. $\mathrm{Xj}$ is the vector of independent variables.

The logistic regression was performed using an econometric software program, LIMDEP 8.0. LIMDEP is an integrated program for estimation and analysis of linear and nonlinear models, with cross section, time series and panel data. An evaluation of the descriptive statistics for the variables that were hypothesized to impact the sourcing mode shows that there were no significant problems of colinearity between the predictor variables. There was a moderate degree of correlation between the prior outsourcing experience of firms and their size indicating that larger firms had more outsourcing arrangements than smaller firms. The interpretation of the coefficients, the negative and significant values of constant terms in the models indicated that the three forms of partnership were used less frequently than internal development in the context of EC systems development. The sourcing modes varied in the degree of hierarchical control with the highest control in internal development and reducing degrees of control in joint ventures, minority equity investments and fee for service contracts. Cost savings expectations varied from firms expecting internal development to result in lower costs to firms expecting external partnerships and expertise to lower costs. 


\section{Conclusions}

This research provided insight into the factors that influence managerial decisions regarding the sourcing modes for EC projects. The hypotheses were tested using a sample of $115 \mathrm{EC}$ projects that were announced by large firms during 2000-2001. By focusing on large firms, mainly in S\&P 500 index, the researchers were able to achieve consistency in size and resources available to firms in the sample. This was considered important because prior research suggest that large firms achieve economies of scale and scope in IT operations, whereas smaller firms do not. Information on these announcements was gathered by extensively searching for information regarding each announcement in the important publications that report developments in Information Technology and are available from the Factiva database. These announcements were then content-analyzed to categorize the evidence regarding each construct of interest and the impacts of the hypothesized variables were tested by a multinomial regressing using LIMDEP 8.0.

In general, it was found that dependence on internal resources was the most commonly used mechanism for the implementation of EC systems in the sample of firms under study. Also, cost savings expectations from outsourcing were an important concern in the outsourcing decision. As the cost savings expectations from outsourcing increased, the extent of substitution by the market for EC development increased. Also, firms tended to use relatively high degree of internal control for EC initiatives with high business potential and avoided the use of fee-for-service mechanisms for implementing such projects. Also, firms that had greater experience in outsourcing, in the sense of having announced a greater number of IT outsourcing contracts in the past, were more likely to use joint ventures to implement EC projects than firms with less experience with outsourcing.

The results have significant implications for IT managers deciding upon the ideal choice of sourcing mode for an EC initiative. The study results summarize the determinants of the choice by the sample of large firms in the study. Cost savings expectations are an important consideration in the choice of sourcing mode. As the expectations of cost savings from outsourcing increased, the firms in the sample increasingly used market mechanisms (service providers) compared to internal resources. Firms were also concerned about the business potential associated with the project and when the business potential was high, they preferred joint ventures and internal development to the use of market mechanisms. This indicates that the move toward outsourcing based on cost savings expectations was mitigated by the desire to develop relevant capabilities for high-potential projects through increased day-to-day involvement.

Finally, a point of interest for service providers was found in the effect of prior outsourcing experience. Firms that had greater experience in outsourcing were more likely to use joint ventures than firms with less experience in outsourcing. This indicates a willingness of firms to use limited forms of market involvement in general as a result of outsourcing experience. Though prior research has found support for the influence of trust between partners on the success of an outsourcing relationship, this research finds empirical support for a move toward market-oriented mechanisms as a result of prior outsourcing experience, indicating that such trust (or some other mechanisms influenced by outsourcing experience of client firms) can actually lead to an increased reliance of market-based mechanisms for the development of EC systems.

The findings of this research have important implications for EC systems development and outsourcing research. In particular, the preference for joint ventures over internal development when business potential is high implies that the sourcing mode decisions for EC systems development represented a balancing act whereby firms retained adequate day-to-day control over development while leveraging the benefits of external expertise. Therefore, suggestions in prior IT outsourcing research that internal development should be the preferred mode when the associated business implications are significant (Lacity et al, 1996) must be qualified in the case of EC. Where appropriate, outside help may provide the 
necessary resources to create a differentiated position with arrangements such as joint ventures providing the necessary opportunities for hands-on experience.

The main limitation of this research was the method of content analysis used to categorize the values of the predictor and dependent variables. Though the researchers took extensive precautions to limit subjective bias, it would be useful to replicate the research using more objective measures for the constructs. There are also limitations associated with limiting the sample to large firms. These firms are likely to maintain extensive in-house IT operations with extensive training and recruitment programs to acquire the relevant skill sets. These firms are also more likely to have slack resources and established mechanisms to set up joint ventures and other forms of partnerships. It would, therefore, be useful to examine the factors that influence the sourcing decisions for EC in smaller firms to see if any additional factors become important. 


\section{References}

Ang, S., \& Cummings, L.L. (1997). Strategic response to institutional influences on information systems outsourcing. Organization Science, 8(3), p. 235-256.

Ang, S. \& Staub, D. (2001). Transaction-specific investments and vendor dominance of the marketplace: The economics of IT outsourcing in International Conference on Outsourcing of Information Systems. Bayreuth, Germany.

Barge, S. \& Poupee, K.. (2002). Les téléphones du futur. Newbiz, vol.22 (iss.4), 62- 72

Baron, R. M, \& Kenny, D.A. (1986). The moderator-mediator variable distinction in social psychological research: Conceptual, strategic and statistical considerations. Journal of Personality and Social Psychology, 51(6), p. 1173-1182.

Beach, L.R. (1997). The psychology of decision making. People in organizations. Foundations for Organizational Science, ed. D. Whetten. Thousand Oaks, CA: Sage Publications.

Brynjolfsson, E. (1994). Information assets, technology and organization. Management Science, 40(12), p. $1645-1662$.

Clemons, E.K. \& Row, M.C. (1991). Sustaining IT advantage: The role of structural differences. MIT Quarterly, (September), p. 275-292.

Crafton, T. W. (2002). Do you really know your customers?. Strategic Finance, 84 (4), 55- 57.

Crosby, L. A.. (2002). CRM and management. Marketing Management, 11 (1), 10- 11.

Dash., J. (2001). Cost cutting may spur IT outsourcing deals. Computerworld.

DiRomualdo, A. \& Gurbaxani, V. (1998). Strategic intent for IT outsourcing. Sloan Management Review, 39(4), p. 67-80.

DosSantos, L.L., Peffers, K., \& Mauer, D.C. (1993). The impact of information technology investment announcements on the market value of the firm. Information Systems Research, 4(1), p. 1-23.

Dyché, J. (2001). The CRM Handbook. Boston: Addison-Wesley.

Earl, M.J. (1996). The risks of outsourcing IT. Sloan Management Review, 37(3), p. 26-32.

Galbraith, J.R. (1977). Organizational design. Reading, Massachusetts: Addison-Wesley.

Grover, V. Cheon, M.J., Teng, J.T. C. (1996). The effect of service quality and partnership on the outsourcing of information systems functions. Journal of Management Information Systems: JMIS, 12(4), p. 89-116.

Gulati, R. (1995). Does familiarity breed trust? The implications of repeated ties for contractual choice in alliances. Academy of Management Journal, 38(1), p. 85-112.

Gulati, R. \& Singh, H. (1998). The architecture of cooperation: Managing coordination costs and appropriation concerns in strategic alliances. Administrative Science Quarterly, 43, p. 781-814.

Hu, Q, Saunders, C., \& Gebelt, M. (1997). Research report: Diffusion of Information Systems Outsourcing: A reevaluation of influence sources. Information Systems Research, 8(3) p. 288-301.

Jauch, L.R., Osborn, R.N., \& Martin, T.N. (1980). Structured content analysis of cases: A complementary method for organizational research. Academy of Management Review, 5(4), p. 517-525.

Kahneman, D. \& Tversky, A. (1979). Prospect theory: An analysis of decision under risk. Econometrica, 47(2), p. 263-292.

Kalustian, J. (2002). CRM checklist for success. Pharmaceutical Executive, 22 (2), 64- 65.

Keil, M. Tan, B.C.Y., Wei, K.-K., Saarinen, T., Tuunainen, V., \& Wassenaar, A. (2000). A cross-cultural study on escalation of commitment behavior in software projects. MIT Quarterly, 24(2), p. 299-325.

Krippendorf, K. (1980). Content Analysis: An Introductions to Its Methodology. Sage Publications.

Lacity, M.C., \& Hirschheim, R. (1993). The information systems outsourcing bandwagon.Sloan Management Review, 35(1), p. 73-86.

Lacity, M.C., Willcocks, L.P., \& Feeny, D.F. (1996). The value of selective IT sourcing. Sloan Management Review. 37(3), p. 13-25.

Lackow, H.M. (2001). Outsourcing trends and best practices. Transition Partners.

Lee, J.-N., \& Kim, Y.-G. (1999). Effect of partnership quality on IT outsourcing: Conceptual framework and empirical validation. Journal of Management Information Systems, Jmis, 15(4), p. 29-61.

Lissack, M. R. (1996). Chaos and complexity - What does that have to do with management? A look at practical applications. Retrieved August 17, 2000 from http://www.lissack.com

Loh, L., \& Venkatraman, N. (1992). Diffusion of Information Technology outsourcing: Influence sources and the Kodak effect. Information Systems Research, 3(4), p. 334-358.

Mahoney, J.T. (1992). Organizational economics within the conversation of strategic management. Advances in Strategic Management, 8, p. 103-156.

Malone, T.W., \& Crowston, K. (1994). The interdisciplinary study of coordination. ACM Computing Surveys, 26(1), p. 87-119. 
Maritan, C. (2001). Capital investment as investing in organizational capabilities: An empirically grounded process model. Academy of Management Journal, 44(3), p. 513-531.

McFarlan, F.W., \& Nolan, R.L. (1995). How to manage an IT outsourcing alliance. Sloan Management Review, 36(2), p. 9-23.

MeindI, J.R., Ehrlich, S.B., \& Dukerich, J.M. (1985). The Romance of Leadership. Administrative Science Quarterly, 30(1), p. 78-102.

Merry, Uri, (1995). The Information Age, New Science and Organizations: Postings to the Newsgroup: Learning Organizations. Retrieved February 12, 2000 from newsgroup at www.news2mail.com/comp/theory/self-orgsys.html

Nam, K., Rajagopalan, S., Rao, H.R., \& Chaudhury, A. (1996). A two-level investigation of information systems outsourcing. Communications of the ACM, 39(7), p. 36-44.

O'Connor, A. (2002). The rise and fall of CRM, part 1. ClickZ. From: http://www.clickz.com/crm/crm_strat/article.php/1007561

Pang, L. M. G.. (2002). Applying customer relationship management (CRM) to government. The Journal of Government Financial Management, 51 (1), 40- 44.

Pargman, D. (2000). Code Begats Community: On Social and Technical Aspects of Managing a Virtual Community [Web site]. From: http://svmud.lysator.liu.se/pargman/

Porter, M.E. (1998). Competitive Strategy: Techniques for Analyzing Industries and Competitors. 432.

Rheingold, H. (1993). The Virtual Community: homesteading on the electronic frontier. Boston: Addison-Wesley.

Rogers, E.M. (1995). Diffusion of Innovations. 4 ed., New York, NY: The Free Press, 519.

Saarinen, T., \& Vepsalainen, A. P. J. (1994). Procurement strategies for information systems. Journal of Management Information Systems, 11(2), p. 187-208.

Sambamurthy, V., \& Zmud, R.W. (1999). Arrangements for information technology governance: A theory of multiple contingencies. MIT Quarterly, 23(2), p. 261-290.

Saunders, C., Gebelt, M., and Hu, Q. (1997). Achieving success in Information Systems Outsourcing. California Management Review, 39(2), p. 63-79.

Sitkin, S.B. \& Pablo, A.L. (1992). Reconceptualizing the determinants of risk behavior. Academy of Management Review, 17(1), p. 9-38.

Sitkin, S.B. \& Weingart, L.R. (1995). Determinants of risky decision-making behavior: A test of the mediating role of risk perceptions and propensity. Academy of Management Journal, 38(6), p. 1573-1592.

Smith, M.A., Mitra, S., \& Narasimhan, S. (1998). Information systems outsourcing: A study of pre-event firm characteristics. Journal of Management Information Systems: Jmis, 15(2), p. 61-93.

Stacey, R. (1993). Strategic Management and Organizational Dynamics, London: Pitman

Staub, D.W., \& Watson, R.T. (2001). Research Commentary: Transformational Issues in Researching IT and NetEnabled Organizations. Information Systems Research, 12(4), p. 337-345.

Stinchcombe, A. L. (1985). Contracts as hierarchical documents, in Organization theory and project management, A. Stinchcombe and C. Heimer, Editors. Norwegian University Press: Bergen, Norway, p. 121-171.

Subramani, M. \& Walden, E. (1999). The Dot Com Effect: The impact of e-commerce announcements on the market value of firms in International Conference on Information Systems. Charlotte, North Carolina.

Teng, J.T. C., Cheon, M.J., \& Grover, V. (1995). Decisions to outsource information systems functions: Testing a strategy-theoretic discrepancy model. Decision Sciences, 26(1), p. 75-103.

Tirole, J. (1998). The Theory of Industrial Organization. Cambridge, Massachusetts: M.I.T. Press. Ven, A.H.V.D., \& Delbecq, A.L. (1976). Determinants of coordination modes within organizations. American Sociological Review, 41(2), p. 322-338.

Venkatraman, N. (1989). The concept of fit in strategy research: Toward verbal and statistical correspondence. Academy of Management Review, 14(3), p. 423-444. 


\section{L'individu comme « ensemble des relations sociales »: une étude des Thèses sur Feuerbach}

Par Dr. Patrice Cailleba

Groupe ESCPau, France 


\section{Résumé}

Dans les Thèses sur Feuerbach, Marx préconise explicitement de prendre en compte le sujet sous son " aspect actif » et plus uniquement comme support de l'histoire, de le considérer comme activité humaine sensible et non comme intuition. Ce faisant, il essaie de définir une " humanité sociale » qui fait de l'essence humaine "l'ensemble des relations sociales ». L'invocation de la subjectivité constitue le leitmotiv qui relit la pratique en particulier de la première thèse à l'activité transformatrice en général de la dernière thèse, de l'activité comme matrice de la pensée à l'activité sociale comme moteur de l'histoire.

\section{Introduction}

Avant d'écrire avec Engels L'Idéologie allemande au cours du second semestre 1845, Marx rédige les fameuses Thèses sur Feuerbach aux mois de mai et de juin ${ }^{1}$. A vrai dire, en guise de rédaction, Marx jette sur le papier quelques réflexions que lui a inspiré la lecture de Feuerbach pour lequel il s'est enflammé jusqu'à peu de mois auparavant et dont La Sainte Famille porte la trace. Ces réflexions en forme de conclusions auxquelles Marx est parvenu comptent au nombre de onze. II a à peine vingt sept ans et toute sa philosophie semble prendre alors une direction nouvelle. Et effectivement, sa philosophie prend une nouvelle orientation, mais non pas celle engagée par ces thèses².

Depuis 1844, Marx s'est progressivement détaché de ses anciens compagnons de route au point de consommer, pense-t-il faussement, sa rupture définitive avec l'idéalisme allemande. Cependant la rupture d'avec Feuerbach, via les Thèses éponymes, marque un pas supplémentaire et décisif par rapport aux Manuscrits de 1844 où seule la philosophie spéculative des épigones de Hegel avait été remise radicalement en cause avant que d'être reprise, bien que différemment, sous la forme de son Naturalisme dialectique ${ }^{3}$. Abandonnant le concept d'homme générique, prisonnier de l'influence feuerbachienne, Marx passe alors, pour un court moment, de l'individu générique naturel à un véritable humanisme social qui esquisse un individu libre bien que défini par son environnement social.

La négation du concept d'homme entendu comme être générique est explicite à partir de 1845. Les raisons de cette négation ne sont pas moins clairement formulées. C'est l'irréalité de l'essence générique qui motive son évacuation hors de la problématique politique. Et cette irréalité n'est rien d'autre à son tour que son idéalité, l'« homme » étant un corrélat de l'idéalisme allemand dont Feuerbach est le dernier épigone. De ce fait, ce qu'affirment les Thèses sur Feuerbach, la figure de l'individu qu'elles dessinent, est dès plus prometteuse. Ce faisant, elles ont séduit plus d'un philosophe ${ }^{4}$.

(1) Bert Andreas, Das Ende der klassischen deutschen Philosophie, Bibliographie, Trier, Karl Marx Hauss, 1983.

(2) Malgré la justesse et la profondeur des analyses de S.A. Salvaggio quant aux Thèses sur Feuerbach, nous ne partageons pas son optimisme, partagé d'ailleurs par la plupart des commentateurs de Marx qui font de ces thèses un condensé de la philosophie de Marx après 1845 . L'Idéologie allemande apparaît alors comme l'approfondissement de l'analyse économique et du poids des déterminations économiques déjà présentes dans les Thèses, ces déterminations économiques étant subsumées dans la possibilité d'une action libre des individus particuliers.

(3) Cailleba P. (2005), L'individu chez Marx, Editions ANRT ; Cailleba P. (2007), Marx and Schmitt Vs. Democracy, Cahiers de Recherche, nº, ESC Pau, Juin ; Cailleba P. (2007), La critique de la théorie de l'exploitation, Cahiers de Recherche, n9, ESC Pau, Décembre.

(4) Plus de 300 traductions ont été faîtes des TsF avec autant d'interprétations différentes selon G. Labica (Karl Marx : les « Thèses sur Feuerbach », PUF, Paris, 1987, p.23). 


\title{
1. Thèses 1 \& 2 : intuition vs. activite
}

Le premier fragment de "l'opuscule » présente l'essentiel des thèmes et des concepts affrontés dans les thèses suivantes. II s'agit d'un exposé propédeutique introduisant le champ problématique du discours à venir en posant les premiers jalons pour la critique : le matérialisme, l'idéalisme, les différents couples objet-sujet, intuition-activité, contemplation-pratique, etc. Cette première thèse définit en fait l'espace à l'intérieur duquel l'analyse va se déployer tout en amorçant l'examen des problématiques sociales et politiques proposées. Elle constitue donc une sorte de condamnation des principaux résultats auxquels Marx était arrivé dans ses textes précédents (en particulier, les textes de la seconde conception de l'individu) en même temps qu'une introduction aux Thèses suivantes.

\subsection{La critique de Feuerbach}

\begin{abstract}
«Thèse I:
Le grand défaut de tout le matérialisme passé (y compris celui de Feuerbach), c'est que la chose concrète, le réel, le sensible, n'y est saisi que sous la forme de l'objet ou de l'intuition, non comme activité humaine sensible, comme pratique ; non pas subjectivement. Voilà pourquoi le côté actif se trouve développé abstraitement, en opposition au matérialisme, par l'idéalisme : celui-ci ignore naturellement la réelle activité sensible comme telle. Feuerbach veut des objets sensibles, réellement distincts des objets pensés : mais il ne saisit pas l'activité humaine ellemême comme activité objective. C'est pourquoi il ne considère, dans l'Essence du christianisme, que le comportement théorique comme véritablement humain, tandis que la pratique n'est conçue et saisie que dans sa manifestation sordidement judaïque. II ne comprend donc pas la signification de l'activité 'révolutionnaire', de l'activité 'pratique-critique'(5). »
\end{abstract}

L'auteur de L'Essence du christianisme n'a jamais cessé de percevoir simplement l'objet, c'est-à-dire de l'appréhender comme une donnée plutôt que comme un produit de l'activité humaine. Alors que l'idéalisme de Hegel intégrait, ne serait-ce qu'à titre abstrait lors de la phénoménalisation de l'Idée dans le monde, «l'aspect actif ", l'activité processuelle de la réalité objective, le matérialisme qui lui a fait suite sous l'impulsion de Feuerbach a marqué à cet égard un net recul. Certes, contre la pure intuition de l'objet, la philosophie critique feuerbachienne avait introduit le sensible, "l'intuition ». Mais, pour n'avoir pas porté son projet à terme, elle n'a pu accéder au processus subjectif de constitution objective de la nature.

L'idéalisme avait été considéré comme une mystification, mais une mystification qui pouvait néanmoins se valoir de la qualité d'accueillir, en tant que contenu, certes spéculatif, de ses propres catégories hypostatiques, la réalité déterminée dont il faisait abstraction. Pareillement à l'hégélianisme qu'elle prétendait contrer, la philosophie feuerbachienne a persévéré à conférer à la réalité objective le caractère spéculatif propre aux hommes. En la critiquant, Marx accomplit un sérieux pas en avant relativement à sa position soutenue dans sa seconde philosophie où il établissait la Nature comme sujet. 
Feuerbach, parce qu'il considère que la seule activité humaine digne de ce nom est l'attitude théorique qui fait du sujet le réceptacle de la nature, tient l'activité pratique pour sordide. Le matérialisme feuerbachien n'a donc de matérialiste que le nom. Marx, en revanche, décèle dans l'activité pratique la capacité de l'homme à agir sur les déterminations de son environnement tant social que naturel. Marx corrobore ici ce qu'il avait déjà avancé dans les Manuscrits de 1844 où il pointait le mérite de Hegel d'avoir cerné la réalité comme une construction du travail humain, mais aussi son tort de se représenter ce travail en tant qu'activité spirituelle abstraite, c'est-à-dire en tant que mystification spéculative du travail effectif accompli par les hommes. Déjà dans les Manuscrits de 1844 et ensuite dans La Sainte Famille, était, par anticipation, présente l'argumentation permettant d'expliquer la signification précise de l'accusation formulée dans la première thèse. Néanmoins, elle restait entièrement déterminée dans le Naturalisme dialectique que Marx définissait lui-même.

La critique du pseudo-matérialisme feuerbachien achève la critique de la philosophie, dans la mesure où ce "matérialisme » s'est révélé impuissant à l'accomplir, dans la mesure également où, sur ses propres bases, il n'est pas parvenu à remettre radicalement en question la théorie idéaliste de la connaissance. Voilà l'autocritique de Marx, puisqu'il a cru jusqu'à présent lui aussi, que la philosophie proposée par Feuerbach suffisait à critiquer et dépasser l'idéalisme hégélien. Le nouvel ancrage à une subjectivité actante vise alors à sortir ce matérialisme du gouffre de l'immobilisme (que lui avait imposé la philosophie du sensible) en vue de le placer dans le sillage dynamique du temps que Marx s'apprête à considérer comme changement et donc comme histoire.

En conséquence, s'en tenir à l'attitude théorique que Marx dénonce d'entrée de jeu équivaudrait à dénier à l'homme son implication directe dans le monde et ce, de façon "sordidement juive ", c'est-à-dire en refusant tout engagement politique ${ }^{6}$. Par ce biais, Marx pose également le problème de la manifestation de l'agir humain puisque son intériorité au monde, tant naturel que social, borne l'espace dans lequel la critique peut seule prendre son sens comme pratique. Alors que la principale objection formulée à l'égard de l'ancien matérialisme était de ne pas avoir tenu compte de l'activité pratique, la principale objection formulée à l'encontre de l'idéalisme est de ne rien savoir sur l'activité sensible réelle de l'homme.

Marx se propose ainsi, dès la première thèse, afin de cerner le processus de changement social, de mettre en lumière les tensions ou les complémentarités entre les combinaisons systématiques globales et l'action des sujets. La solution qu'il entrevoit de ce problème du devenir des groupes humains ne réside ni dans l'idéalisme ni dans le matérialisme. La place centrale qu'il confère à la pratique fait peser ses conséquences bien au-delà de la simple récusation de la proposition feuerbachienne et de la tradition hégélienne. Elle conduit Marx à interpréter la société comme le lieu et le résultat de la pratique.

Dans la mesure où Marx considère toute pratique comme une mise en mouvement de matières, d'objets, de sujets, de pensées, sa centralité fait de la relation entre éléments le seul horizon du sens sociologique et historique. La théorie de la socialité fait, en partie, chez Marx l'économie du passage par la conscience. L'action sociale (la praxis), quant à elle, appelle le retour à la conscience subjective, à l'intentionnalité et à l'interprétation des données du réel. La critique de la philosophie spéculative et de l'idéologie constitue le lieu théorique de la dénonciation des errances de la conscience par rapport au substrat objectif dans lequel elle s'enracine.

Dans l'optique de Marx, l'adoption d'une perspective ontologique n'équivaut pas au retour à une métaphysique du sujet absolu fallacieusement débarrassé de l'idéologie et de la fausse conscience, mais à

(6) Nous ne reviendrons pas sur "l'antisémitisme " de Marx, lui-même descendant d'une famille de rabbins. Nous soulignerons seulement qu'ici Marx reprend, non un des résultats des réflexions qu'il avait nourris lors de sa première conception de l'individu, mais un état de fait dont il avait négligé, et continue à négliger, les tenants historiques. Cette erreur, à savoir l'oubli du rôle historique de certaines obligations faîtes à des minorités, qui, sans être excusable, peut paraître compréhensible en 1842 et en 1845, disparaîtra après les TsF puisque Marx fera de l'Histoire un agent et de l'individu un produit de déterminations. II ne sera plus question alors de condamner telle ou telle minorité puisque l'humanité sera, au sens propre, " classée », i.e. distinguée en classe. A partir de L'ldéologie allemande, le fait social l'emporte, chez Marx, sur le fait culturel. L'histoire est linéaire et toutes les sociétés humaines doivent passer par les mêmes étapes dont la société capitaliste représente l'antépénultième étape (avant la société socialiste et la société communiste). 
la recherche dans la théorie d'un idéal régulateur de l'intelligibilité du système déterminant et des modalités de l'action. Dès lors, comme l'ont écrit Denis Fisette et Pierre Livet, le problème de l'action en partant de la praxis (qui est toujours sociale, comme nous le verrons), autrement dit "le problème de la liaison entre l'intentionnalité et l'action n'est pas central. Les intentions subjectivement investies de l'action peuvent en effet être faussées par une représentation idéologique, et l'analyse des déterminants socio-économiques de la praxis se doit d'échapper à ces points de vue 'mystifiés'7» .

L'élément moteur de la philosophie marxienne réside dorénavant dans l'action et moins dans la philosophie. L'intuition cède le pas à la relation immédiate du sujet et de l'objet par la prise en compte des potentialités productives (poïétiques) du sujet historique qui, parce qu'il peut travailler à la métamorphose du monde, contribue à son auto-transformation en tant qu'élément de ce monde. La première thèse prépare l'avènement de la onzième : le sujet produit le monde et se produit lui-même comme objet.

Une contradiction surgit néanmoins entre, d'un côté, les axes normatifs du système social objectif et, de l'autre, l'irréductibilité de l'action en tant que rapport de l'être au monde du sujet et des contingences socio-historiques constituées. L'indétermination de l'action survient et se développe toujours d'emblée dans un contexte réel qui l'encadre, la produit mais aussi en résulte.

Alors qu'auparavant l'homme s'identifiait à une essence générique naturelle (second individu), après s'être incarné dans le citoyen grec (premier individu) ${ }^{8}$, Marx tire maintenant l'essentiel de son argumentation de la composante majeure de la vie, c'est-à-dire le sensible, la matière - notons qu'il n'est pas question ici de vie matérielle ou de production, même au sens large -, en accordant à ce facteur objectif une sorte de primauté sur les autres facteurs.

Dès lors, penser ne peut plus être synonyme de contempler. La théorie ${ }^{9}$ comme pensée pure ou pensée critique, n'a plus droit au trône de l'histoire : séparée de la pratique sur laquelle elle se déploie, la pensée pure produit un univers dans lequel la pensée est incapable de cerner les objets externes et d'établir avec eux un rapport concret. Sans support, elle s'effondre ou tourne à vide. Dans ces circonstances, la question de la réalité de la pensée ne se pose plus, elle ne peut d'ailleurs être posée sinon comme " purement scolastique ». L'intériorité, par définition, des objets de la pensée commande, pour retrouver l'objectivité sensible de la Nature, de faire état d'une intuition phénoménique et, surtout, d'une action pratique sur les réalités du monde (institutions, normes, valeurs, symboles, affects, etc.). Ceci nous amène à la deuxième thèse.

\subsection{Une pensée pratique}

\section{" Thèse II :}

La question de savoir si le penser humain peut prétendre à la vérité objective n'est pas une question de théorie, mais une question pratique. C'est dans la pratique que l'homme doit prouver la vérité, c'est-à-dire la réalité et la puissance, l'ici-bas de sa pensée. La querelle de la réalité ou de l'irréalité du penser - qui est isolé de la pratique - est un problème purement scolastique ${ }^{10}$."

(7) Denis Fisette et Pierre Livet, "L'action mise en cause ", Actuel Marx, n¹3, 1993, pp.89-115

(8) Cailleba, Ibidem.

(9) Dans la version de M. Rubel, " théorie » est la traduction de Anschauung, signifiant « vision », " contemplation ».

(10) TsF [1845] in PI III, p.1030. 
La pensée à laquelle Marx accorde son crédit dépend toujours circulairement d'une pratique dans le monde. Et lorsqu'elle s'isole, comme ce fut le cas dans la pensée spéculative (surtout post-hégélienne) mais aussi dans le matérialisme intuitif de Feuerbach, elle continue de dépendre d'une pratique sociale qui entretient l'illusion de son isolement.

La deuxième thèse a une portée considérable dans la théorie de la connaissance car elle rejette tant la pure équivalence entre objet et sujet que le clivage entre eux, entre la théorie et la pratique, que ce clivage soit interne à l'Idée (Hegel), condition de la connaissance (Kant) ou principe ontologique (Feuerbach). La pensée est de l'ordre de la pratique : elle est inconcevable, inappréhendable sans elle, car elle est pratique. A la faveur d'un projet de refonte paradigmatique de l'épistémologie, Marx se charge ainsi de réduire les dualités constitutives des anciens schèmes de la pensée. Les couples oppositionnels pensée/pratique, objet/sujet, sont revus de manière transversale. De même que l'objectivité et la subjectivité se rencontrent, la pensée et la pratique se mêlent, sans répulsion mutuelle de l'un envers l'autre.

L'homme est porteur de la pensée, ou " sujet pensant », dans la mesure où il est lui-même un être naturel-historique, sujet-objet de sa propre évolution-transformation, producteur et produit d'un complexe ensemble de déterminations. II ne s'agit pas d'une union - ce qui impliquerait une séparation préalable, antérieure à leur rencontre - mais d'une alliance commune dès l'origine.

Le savoir, et plus fondamentalement "le penser humain " ne reflètent pas la réalité. Cette conception n'aboutirait d'ailleurs qu'à avaliser ce que Marx récuse, à savoir l'idée de la séparation du sujet et de l'objet. Monde et conscience nourrissent un rapport d'interrelation et non un rapport de subsomption. La pensée n'est pas le réceptacle passif du monde perçu. Par son rôle actif, elle interprète et invente les hypothèses sur le monde et ne se laisse pas réduire à un mécanisme d'enregistrement des faits. Le savoir se déploie de manière circulaire comme processus interactif qui consent au sujet de pénétrer la complexité du monde constitué pour la réduire au moyen de la production d'un nouveau savoir.

Aussi, penser qu'il soit possible de produire une théorie de la connaissance qui la relègue au statut d'enregistrement de faits externes équivaut à passer sous silence le caractère constructif de toute théorie de la connaissance qui non seulement reformule le monde au départ de catégories de pensée imprégnées de leur origine sociale mais aussi englobe les pratiques et les conditions d'existence sur lesquelles se projette l'activité structurante des sujets au sein de ce monde qu'ils contribuent continuellement à produire et auquel ils donnent un sens ${ }^{11}$. Les conclusions tirées des actions subjectives revêtent alors un caractère toujours temporaire puisque le changement du monde et donc des données pertinentes pour l'action apparaît incessant. Ceci amène à distinguer deux choses : un sens cognitif inhérent à la formulation d'un savoir sur le social et un sens éthique inhérent au projet de transformation de ce même social. Social pour lequel il n'est pas précisé qui doit le transformer (le prolétariat seul ou tous les individus associés ?) ou contre quoi ou qui il doit être transformé (la société bourgeoise ? la bourgeoisie ?).

La pensée émerge à l'intersection des conditionnements normatifs de la socialité et de la praxis subjective, à l'intersection donc de la détermination par le contexte socio-historique et de la capacité subjective de la négation du naturant. Elle n'est pas une entité pré-catégorielle, mais résulte des multiples interactions du contexte et de l'acteur puisque l'homme, sujet de la connaissance, émerge à la fois comme sujet et objet de son évolution sensible ${ }^{12}$.

(11) Pierre Bourdieu, La distinction, Les Editions de Minuit, Paris, 1979 ; Questions de sociologie, Les Editions de Minuit, Paris, 1980.

(12) G. Labica, Karl Marx, Les TsF, P.U.F., Paris, coll. "Philosophies », 1987, p.52. 
Par conséquent, dès ces premières lignes, on devine que c'est la structure de l'être comme ce qui est vu, comme un objet ${ }^{13}$, qu'en leur visée ultime les Thèses sur Feuerbach viennent récuser. Alors que le renversement feuerbachien vise à substituer l'être sensible à l'être intelligible, reconnaissant ainsi les droits de la donation intuitive comme plus fondamentaux, Marx "renverse » ce renversement dans les Thèses ${ }^{14}$.

Ni l'objet sensible, ni l'objet scientifique ne sont mis à l'envers ou encore anéantis. L'un et l'autre subsistent la où ils sont, devant nous. Le problème de l'être et de la réalité est alors abordé franchement. La problématique qui vise la réalité de l'être ne prend plus en considération le voir de la theoria, le voir de l'intuition ou celui de la pensée et, laissant ce voir subsister là où il est, laissant se déployer ce qui est vu là où il est vu, elle indique que la réalité originelle de l'être réside ailleurs, en un autre lieu et c'est vers celui-ci que désormais elle se dirige consciemment.

Qu'est-ce que l'Être alors ? C'est l'action, la praxis. Feuerbach s'est trompé parce qu'il a cru saisir l'essence de la réalité dans l'intuition et par suite l'être comme un objet, alors que la réalité dans l'intuition et par suite l'être comme un objet, alors que la réalité de cet être, la réalité de la réalité, réside au contraire de façon originelle et exclusive dans la pratique qui ne désigne elle-même rien d'autre que l'activité, que la pure activité comme telle.

"Le grand défaut de tout le matérialisme passé (y compris celui de Feuerbach), c'est que la chose concrète, le réel, le sensible, n'y est saisi que sous la forme de l'objet ou de l'intuition, non comme activité humaine sensible, comme pratique $(. . .)^{15}$ »

Que l'essence originelle de l'être - et conjointement celle de la vérité - réside dans la praxis, que toute pensée vraie, objective, c'est-à-dire susceptible de se référer à l'être et de reconnaître le lieu de la vérité, doive reconnaître du même coup son inaptitude principielle à constituer par elle-même ce lieu et cette essence originelle de l'être et de la vérité, la nécessité où elle se trouve de faire appel à autre chose qu'à elle-même, qu'à la théorie, sa nature référentielle, l'expression de cette référence essentielle dans le « il faut » de la prescription, tout cela est déjà contenu dans le texte trop dense de la deuxième thèse où se concentre le renversement accompli par Marx, le renversement ontologique ultime de la théorie dans la pratique.

(13) Ici se découvre à nous la signification fondamentale de concept de théorie qui désigne à la fois l'intuition du monde sensible et la détermination catégoriale de ce monde, sa "théorie " stricto sensu. Que tel soit bien le concept feuerbachien de la théorie que les TsF vont mettre en cause, c'est ce que dit explicitement ce texte de Feuerbach : "(...) l'objet essentiel de la théorie - cette dernière étant entendue en son sens le plus originel et le plus général, au sens de l'intuition et de l'expérience objectives, de la raison, de la science en général (...) » (L'Essence du christianisme, trad. J.-P. Osier, Maspero, Paris, 1968, p.333).

(14) On se méprend lorsque, comme L. Althusser, on prétend écarter l'opposition de la pratique et de la théorie en la référant à la pensée du " jeune Marx », en la situant dans la problématique feuerbachienne à laquelle elle appartiendrait encore. L. Althusser, Pour Marx, La Découverte Poche, Paris, 1996

(15) TsF [1845] in PI III, p.1030. 


\title{
2. Thèses $3,4 \& 5$ : dédoublement et praxis
}

Deux axes organisent le contenu de la troisième thèse : le problème posé par le matérialisme traditionnel qui amène à une impasse et la solution de Marx à ce problème, à savoir la " praxis révolutionnaire » ou " pratique révolutionnaire».

\subsection{Eduquer l'éducateur}

\begin{abstract}
« Thèse III
La doctrine matérialiste de la transformation par le milieu et par l'éducation oublie que le milieu est transformé par les hommes et que l'éducateur doit lui-même être éduqué. Aussi lui faut-il diviser la société en deux parties, dont l'une est au-dessus de la société.

La coïncidence de la transformation du milieu et de l'activité humaine ou de la transformation de I'homme par lui-même ne peut être saisie et comprise rationnellement que comme praxis révolutionnaire. ${ }^{16 »}$
\end{abstract}

La doctrine matérialiste à laquelle Marx s'en prend a considéré l'immuabilité des circonstances et le caractère inné de l'éducation. Elle a ainsi laissé apparaître au grand jour ses deux lacunes : d'un côté sa persistance à appréhender le monde sensible comme donné une fois pour toute à la visée théorique de l'homme et, de l'autre, son incapacité à saisir l'homme au cœur du processus de son auto-formation. L'homme est tout à la fois nature et histoire, vie et conscience, producteur et produit, sujet et objet. On ne va pas de l'individu à la société, comme le font les tenants des robinsonnades, étrillés par Marx, mais l'inverse. L'Idéologie allemande reprendra cette idée en affirmant que la " conscience est donc dès l'origine un produit social et le demeure aussi longtemps qu'il existe des hommes, tout simplement » 17 .

La doctrine matérialiste a voulu éduquer l'homme. Mais qui peut bien éduquer l'homme, si ce n'est un autre homme ? Car la doctrine matérialiste est bien le produit d'une intelligence humaine particulière, voire le fruit de plusieurs hommes. Or, ces hommes, sans exception, sont déterminés par tout un ensemble de circonstances. Ils ne peuvent s'en défaire sans se départir de leur réalité d'homme. L'homme produit et se produit. Par cela il ne faut pas exclusivement entendre une production industrielle, mais la création des conditions de manifestation de sa vie. Cependant, la relation de conditionnement n'est pas univoque car le sujet se retrouve tant à l'origine des déterminations qu'à leur accomplissement, tout à la fois libre de choisir et limité par l'ensemble des compossibles.

Alors, comment peut-on parvenir à faire de certains hommes des éducateurs, des leaders ou des intellectuels qui seront à même de changer l'espace de déterminations que l'on nomme monde ? Marx précise que "l'éducateur doit lui-même être éduqué », mais comment ? II faut, par conséquent, obligatoirement scinder artificiellement la société en deux pour placer à ses extrêmes, d'un côté, les hommes à transformer et, de l'autre, les hommes qui les transformeront - les éducateurs. Et voilà, tout le drame du matérialisme classique. 
L'impasse à laquelle la doctrine matérialiste mène est celle de toutes les philosophies politiques avant Marx. L'homme intervient dans le réseau des déterminations qu'il contribue à créer. Cela implique qu'il se pose d'emblée en tant qu'être de société où converge et se fixe l'ensemble des conditionnements socio-historiques. Autrement dit, parce que l'homme appartient au plan d'immanence de la société, le changement qu'il imprime à son environnement, au tissu des relations dans lequel il évolue, se réalise de manière interne à la société. Et la pratique de cette mutation se résume à une action qui synthétise le rapport entre déterminisme limité et hasard contrôlé. Le caractère indissociable du milieu et de l'activité humaine évacue toute extériorité : le changement est auto-changement.

Néanmoins, la doctrine matérialiste n'explique pas comment certains hommes peuvent se dégager du reste de l'humanité déterminée en s'arrogeant le droit de devenir des éducateurs. Quel est l'instrument de leur libération ? Comment et d'où tirent-ils leur légitimité à dicter aux autres hommes ce qu'ils doivent faire?

Le concept d'homme, tel que Marx le développe, inclut simultanément les dimensions de nature et culture, présent et histoire, objet et sujet, pensée et pratique, individu et société18. Dans ce dernier cas, on pourrait d'ailleurs aller plus loin en soulignant l'équation entre subjectivité et socialité. Comme individu, l'homme marxien est une conséquence partiellement déterminée de son histoire et de ses rapports sociaux. II subit un conditionnement probable qui n'élimine pas la sphère semi-aléatoire des décisions individuelles. Pour comprendre l'homme, Marx part de la société et non l'inverse afin de porter à la lumière l'immédiateté de son immersion sociale.

Aussi, Marx récuse la conception classique de la doctrine matérialiste et de sa conception de l'éducation : il lui préfère la conception de praxis révolutionnaire qu'il laisse ici inexpliquée ${ }^{19}$. Pour autant, l'unité de l'homme et de la nature qui semble s'affirmer via la praxis n'a cependant rien à voir avec celle qui trouvait en 1844 son expression dans la subsumption de l'humanisme dans son Naturalisme dialectique, malgré ce que Marx pouvait en dire puisqu'il identifiait les deux. Ce n'est plus d'une unité, à vrai dire, qu'il s'agit ; mais la praxis en constituant l'être de ce qui se trouve représenté comme nature constitue l'essence de cette apparence et son fond caché. La fausse identification de l'homme et de la Nature, la vraie descendance de l'homme par la Nature, se traduit, en 1844, par une essence naturelle comprise comme objectivation. En 1845, il s'agit d'une identité ontologique structurelle de la praxis et de la théorie. Identité qui rejette toute aliénation, notamment religieuse.

\subsection{La critique feuerbachienne de la religion}

Dans la quatrième thèse sur Feuerbach, nous passons de la critique de la " doctrine matérialiste du changement des circonstances et de l'éducation » à la critique de la doctrine matérialiste de la religion. Marx aborde, ici, par deux biais successifs le problème du dédoublement du monde. D'abord il prend acte du renversement que Feuerbach impose à l'ordre des préséances, ensuite il se penche sur le moment producteur de l'aliénation.

(18) G. Labica, Marx. Les TsF, P.U.F., Coll. "Philosophies », Paris, 1987, p.58.

(19) Pour autant que la "praxis révolutionnaire " reste inexpliquée, nous ne souscrivons pas à la définition qu'en donne M. Henry lorsqu'il dit qu'elle est «pour l'essentiel, une activité théorique et la part d'activité réelle qu'elle implique n'est qu'une conséquence qui demeure le plus souvent circonscrite dans sa matérialité à des actions limitées pour ne pas dire dérisoires (vente de journaux, distribution de tracts, assistance à des réunions, etc.).»(M. Henry, Marx, tome I : Une philosophie de la réalité, Gallimard, Paris, 1976, réed. 1991, p.356). Les Thèses laissent deviner bien plus qu'une simple activité théorique. En ce qui concerne le reste de l'œuvre marxienne postérieure aux Thèses, la praxis révolutionnaire disparaîtra au profit de concepts plus " pratiques », plus explicites. Cf. Infra. 


\section{« Thèse IV}

Feuerbach part du fait de l'aliénation religieuse de soi, du dédoublement du monde en un monde religieux et un monde profane. Son travail consiste à dissoudre le monde religieux dans son assise profane. Mais si l'assise profane se détache d'elle-même et se fixe dans les nues, tel un royaume indépendant, cela ne peut s'expliquer que par le déchirement de soi et par la contradiction à soi-même de cette assise profane. II faut donc tout autant comprendre cette assise en ellemême, dans sa contradiction, que la révolutionner pratiquement. Ainsi, une fois que l'on a découvert, par exemple, que la famille terrestre est le secret de la Sainte Famille, c'est la première elle-même qui doit être anéantie en théorie et en pratique. » 20

L'anthropologie, avec le concept de Gattung, est la conclusion à laquelle arrive Feuerbach au terme de sa critique de la religion. Néanmoins, cette anthropologie feuerbachienne reconduit l'existence mondaine à la métaphore de la présence de l'absolu divin. Feuerbach fait pencher la balance du côté du matérialisme, il renverse le clivage et attribue le primat au monde sensible. II refuse la mystification par laquelle le monde se dédouble et s'abaisse devant le religieux qui lui fait face et le domine de l'extérieur. Ce faisant, le renversement qu'accompli Feuerbach ne modifie pas sensiblement la structure globale de l'espace de pensée, il continue à distinguer deux sphères séparées et fait de sa philosophie un sous-hégélianisme.

Ce n'est qu'au titre de fait de la pensée que Feuerbach exclut la suprématie du religieux, car son matérialisme qui l'a induit à privilégier l'ici-bas ne détecte nullement le mécanisme de production sociale d'une sphère autonome. II se montre incapable d'expliquer la constitution sociale de ce dédoublement. Marx, en revanche, suggère que le monde religieux qui s'isole de sa base sociale dépend encore de contradictions internes à cette base profane, c'est-à-dire qu'il continue à subir l'influence de déterminations réelles qui lui permettent d'entretenir l'illusion de son autonomie. Marx reproche ainsi à Feuerbach son silence sur la production de l'aliénation, de l'idéologie et de la religion²1.

L'auteur de L'essence du christianisme intervertit des essences mais ne quitte pas le terrain de la spéculation. Avec lui, l'aliénation est atteinte d'amnésie sur les conditions et le processus de sa production alors que Marx insiste au contraire sur l'origine mondaine du religieux. Etrangement Marx n'insiste pas sur les autres formes d'aliénation qu'il avait déjà identifiées auparavant.

Dans l'objectif de pénétrer la logique de cet état de fait, et de réduire la fracture entre l'ici-bas du phénomène et l'au-delà de l'imaginaire, Marx préconise d'en comprendre les mécanismes d'émergence et de consolidation, d'en saisir les tenants et les aboutissants, de dégager les processus de sa production et reproduction sociales. Mais il ne se limite pas à la dimension cognitive de la critique : il met l'accent sur la nécessité de modifier le fondement sensible de l'aliénation pour en annihiler les conditions de possibilité. 
La cinquième thèse résume, après les avoir plus largement exposés dans les thèses III et IV, les concepts que Marx avait présentés dans la première thèse. Bien que Feuerbach ne se satisfasse pas de la religion, l'intuition sensible qu'il développe dans son matérialisme consiste encore en une appréhension externe d'un objet visé et donné. Feuerbach reste enfermé dans la contemplation et ne parvient pas à rendre intelligible la production humaine du sensible. L'activité et la praxis font encore défaut au matérialisme de Feuerbach que Marx s'efforce de dépasser.

\section{"Thèse $\mathbf{V}$}

Peu satisfait du penser abstrait, Feuerbach veut la contemplation ; toutefois, il ne conçoit pas le sensible comme activité pratique humaine et sensible. »22

L'essence humaine, loin de pouvoir définir la réalité des individus, n'est que la représentation de cette réalité dans une philosophie de la conscience. L'homme feuerbachien - l'individu représenté - est identiquement l'homme de la conscience, c'est-à-dire aussi bien celui dont parle l'idéologie. Voilà pourquoi les individus réels surgissent comme thème de la problématique au moment où ils se substituent à leur représentation philosophique illusoire, i.e. au moment où l'humanisme feuerbachien s'effondre. Feuerbach, loin de rompre avec la philosophie allemande, en libérant l'horizon de sa problématique propre, la poursuit et se perd dans l'idéalité de la contemplation. Alors qu'il refuse de prendre en considération l'activité pratique sensible de l'homme, Feuerbach échoue à proposer une philosophie novatrice.

\section{Thèses 6 \& 7 : L'essence sociale de l'homme}

Les individus réels ne sont plus et ne peuvent plus être, comme chez Feuerbach, le fruit d'une intuition, les particularisations et les actualisations du genre, trouvant en lui à la fois leur réalité et leur finalité. Marx bannit l'intuition intellectuelle feuerbachienne et fait de l'activité pratique humaine et sensible le leitmotiv de sa nouvelle philosophie.

\subsection{L'essence humaine comme l'ensemble des rapports sociaux}

Dans la sixième thèse ${ }^{23}$, Marx précise sa conception de l'essence humaine et marque à cette occasion sa différence par rapport à Feuerbach. Exit l'essence naturelle de sa seconde conception de l'individu, reprise à Feuerbach; exit l'humanisme-rationaliste de sa première conception ${ }^{24}$. La répudiation du genre signe la rupture d'avec l'anthropologie feuerbachienne et désigne la voie nouvelle où il va s'engager. Pour Marx, l'homme est l'ensemble des rapports sociaux.

(22) TsF [1845] in PI III, p.1031-32. Labica, Bensussan et Lefebvre traduisent par " intuition » au lieu de " contemplation » (G. Labica, Karl Marx : les "Thèses sur Feuerbach », PUF, Paris, 1987, p.21)

(23) La traduction française de cette sixième thèse a donné lieu à une âpre polémique entre Adam Schaff et Lucien Sève (les articles de cette polémique ont d'abord été publiés dans la revue L'Homme et la Société, n¹9-20-22-24-25-26, 1971-1972). L'essentiel du débat porte sur le terme allemand Wesen que Schaff traduit par 'individu' alors que Sève, plus correctement à notre sens, traduit par 'être' (dans le sens de 'essence'). Sève dénonce l'interprétation avancée par Schaff dans Le marxisme et l'individu (Colin, Paris, 1968) puisqu'elle est entièrement basée sur cette erreur de traduction.

(24) Cailleba, Ibidem 


\section{« Thèse VI}

Feuerbach réduit l'essence de la religion à l'essence humaine. Mais l'essence humaine n'est point chose abstraite, inhérente à l'individu isolé. Elle est, dans sa réalité, l'ensemble des relations sociales.

N'abordant pas la critique de cette essence réelle, Feuerbach est obligé :

$1^{\circ}$ de faire abstraction du cours historique et de fixer le sentiment religieux pour soi, en supposant un individu abstraitement - isolément - humain.

$2^{\circ}$ de ne concevoir l'essence que comme 'genre', comme généralité intérieure, muette, qui relie de manière naturelle la multitude des individus. ${ }^{25}$

On ne peut définir le social comme alignement indéfini d'une multitude de sujets ou d'inter-subjectivités. II est un principe naturant, une institution qui dépasse les singularités tout en les contenant, tout comme il contient son principe de perpétuation et de développement alors que ses composantes demeurent provisoires. Bien que l'individu soit mortel, le social ne l'est que sous d'autres formes, sous d'autres modalités et en fonction d'une temporalité incommensurable à celle des hommes. Quant aux sujets singuliers, cette appartenance à une dimension qui les traverse façonne leur existence et les subsume sans pour autant les soumettre ou les contraindre absolument. Bref, le mythe de l'individu isolé est une abstraction qui tire sa force de sa simplicité.

Contrairement à l'avis de Guy Haarscher ${ }^{26}$, il apparaît que la sixième thèse va dans le sens d'une détermination ontologique de l'essence humaine dont il faut examiner les différentes manifestations concrètes. Bien plus, le caractère ontologique du sujet constitue le thème spécifique au départ duquel le matérialisme marxien se déploie. L'essence humaine réelle telle que Marx l'appréhende ne se résume pas en une abstraction, il s'agit d'un ensemble de déterminations concrètes qui pénètrent le sujet et permettent par conséquent de combler le déficit de réalité laissé par la précédente valorisation de l'essence générique, reprise à Feuerbach.

Loin de marquer le point final de l'homme, la réalisation de potentialités ou de vertus préexistantes, la véritable essence humaine résulte, au contraire, d'une histoire. Cependant jamais le résultat ne se fige puisque son actualité s'inscrit dans le mouvement du présent, I'hic et nunc d'un devenir en acte. La substance de l'essence humaine réelle réside toujours dans la synthèse improbable et dynamique d'un effet du passé et d'une amorce du futur. Elle marque le point de départ d'une effectivité à venir dans le processus interne de son changement comme transformation continue des rapports sociaux. La logique actorielle s'introduit à l'intérieur de l'analyse des interdépendances systémiques qui lui confèrent son sens et sa stabilité, dans la faille béante de la confrontation entre déterminisme de structure et volontarisme individuel. Marx procède ainsi à une sorte d'antonomase conceptuelle par laquelle il remplace la dénomination d'une entité physique existante par une qualité essentielle propre à l'objet qu'elle désigne : il substitue à l'individu sa socialité.

De cette manière, Marx avance l'idée que, puisque l'individu ne peut être appréhendé comme acteur du changement que comme être social, il faut, pour en cerner les mécanismes, faire un examen du rapport social dans lequel cet acteur est pris. De ce fait, est condamné d'emblée le subjectivisme ou volontarisme qui conçoit l'acteur comme le créateur libre du sens dans la transparence de l'expérience vécue où tout naturant s'abolit. De même, est fustigé le déterminisme qui commet l'erreur de considérer les cadres dégagés par l'observateur comme le principe réel qui inspire directement l'action du sujet en oubliant de consi- 
dérer les potentialités innovatrices de la praxis. Ainsi jamais la réalité ne s'impose-t-elle dans son objectivité aux sujets, elle est intermédiée par l'activité symbolique de ceux-ci. Et si elle sous-tend le principe d'intelligibilité de l'action, elle n'en constitue que très rarement la motivation subjective.

Pour la première fois de manière aussi explicite, un texte de Marx introduit les rapports sociaux contre la singularité de l'individu et contre l'essence humaine abstraite, l'historicité des sociétés contre le genre. Ceci marque clairement la frontière entre la philosophie idéaliste allemande (avec celle de Feuerbach) et l'ébauche d'une philosophie marxienne attachée à la réalité empirique de la vie où se déploie l'action subjective.

Deux ans auparavant, pour sa toute première philosophie, Marx avait déjà fait référence à une conception proche de l'individu, mais celle-ci demeurait "politique ", " citoyenne ", au sens où la Cité constituait le lieu où se réalisait véritablement I'homme. D'aucuns objecteront donc que cette thèse sur Feuerbach reprend la Critique de la philosophie du droit de Hegel - Introduction, à savoir que l'homme :

" n'est pas un être abstrait, recroquevillé hors du monde. L'homme, c'est le monde de l'homme, c'est l'État, c'est la société. ${ }^{27}$ »

Mais cette sixième thèse développe avec bien plus de profondeur l'intuition théorique que Marx avançait alors. Délaissant l'homme générique feuerbachien, passant outre l'illusion " classique " d'un individu doué de raison au profit de l'homme social et historique, Marx se livre à une forme d'autocritique en dépassant ce qu'il avait écrit et repris auparavant dans la Question juive et dans ses Critique(s)... à Hegel, en particulier celle concernant son Naturalisme dialectique. Marx se tourne ainsi vers un matérialisme essentiellement tourné vers l'élucidation des pratiques actorielles dans le cadre complexe et englobant du lien social. Le fondement individuel ou générique du social se trouve rejeté en faveur d'une affirmation multi-factorielle du monde humain et des interactions qui y prennent place ${ }^{28}$.

Le changement social apparaît dès lors possible à l'intersection de la structure et du sujet, à l'intersection des règles et de la déviance, là où l'action met en relation l'héritage socio-historique ("I'ensemble des relations sociales "- sixième thèse) avec les choix des acteurs (" la modification des circonstances » par la « praxis révolutionnaire »-troisième thèse). L'action développée par les acteurs (niveau subjectif) contribue à alimenter et à reproduire la structure sociale (niveau objectif) tout en y introduisant des variations. Elle ne se limite pas à advenir dans une structure normative ; elle est à la fois son produit et sa productrice. Dès lors, Marx renouvelle profondément la question de l'homme, à savoir comment il faut définir sa nature, son essence.

Que Marx pousse à l'avant de la scène le rapport social comme noyau constitutif de son anthropologie n'implique pourtant pas un abandon total de toute conception de l'essence humaine. Effectivement, on cite généralement la sixième thèse pour illustrer le rejet marxien de l'idée d'essence ou de nature humaine. Or, N. Geras ${ }^{29}$ soutient, lui, qu'il n'en va pas ainsi. II démontre que l'idée d'une nature humaine joue à la fois un rôle explicatif et une fonction normative. Par " nature humaine », il faut entendre :

- la référence à une entité constante, à des qualités universelles des êtres humains (liberté, sensibilité, etc.) ;

- la référence à une entité variable en fonction du moment historique, de lieu géographique et à des circonstances.

(27) I-M43 [1843] in $P / I I I$, p.382.

(28) Douze ans plus tard, Marx reprendra cette idée, mais le contexte dans lequel se situera l'individu aura changé : ce dernier sera entièrement déterminé. Pour autant, Marx paraîtra s'inscrire dans la lignée des Thèses qui poursuivaient une longue tradition philosophique entamée avec Aristote : "L'homme est, au sens le plus littéral du terme, un zoon politikon, il est non seulement un animal social, mais un animal qui ne peut s'individualiser que dans la société. L'idée d'une production réalisée par un individu isolé, vivant en dehors de la société (...) n'est pas moins absurde que l'idée d'un développement du langage sans qu'il y ait des individus vivant et parlant ensemble. » (I-CEP [1857] in PI I, p.236).

Cette phrase qui a trompé nombre d'exégèses est précédée de plusieurs phrases qui ne laissent aucun doute quant à la détermination dont pâtira, après les Thèses, l'individu chez Marx : "Des individus qui produisent en société - donc une production d'individus socialement déterminée, tel est naturellement le point de départ », puis, plus loin, "Plus nous remontons dans l'histoire, plus l'individu - et par suite l'individu producteur également - apparaît comme un être dépendant, partie d'un ensemble plus grand (...) ». (I-CEP [1857] in PI I, p.235 et 236).

(29) Norman Geras, Marx and Human Nature: Refutation of a Legend, Verso Editions, London, 1983, p.23 et sq 
Ces deux acceptions ne sont pas, pour Geras, mutuellement exclusives car on peut considérer la nature humaine comme un ensemble de traits variables qui se développent sur un substrat invariant. Nous pensons, en effet, que c'est ce que semble affirmer Marx dans la mesure où derrière les rapports sociaux qui indéniablement encadrent l'homme, un fond d'essence humaine subsiste chez un individu relativement doué de raison qui, malgré l'importance nodale des rapports sociaux conserve sa liberté de choix, la possibilité d'être libre.

Certains ont voulu voir simplement dans cette sixième thèse les prémices du Manifeste du Parti Communiste où Marx fait état de I'histoire des rapports entre esclaves et citoyens, entre serfs et seigneurs, entre prolétaires et capitalistes. L'Idéologie allemande fera également référence à l'historicité des classes et des luttes prolétariennes. Cependant, faire un amalgame entre la thèse VI et le Manifeste reviendrait à oublier que Marx ne parle pas une seule fois du prolétariat, de classes sociales ou d'une hypothétique lutte des classes au cours des Thèses sur Feuerbach, même si la plupart des exégèses des Thèses se font fort d'en deviner les références entre les lignes.

En tout cas, nous pouvons, à l'image de G. Labica30, relever la structure de la Thèse 6 comme étant la suivante :

\begin{tabular}{ll}
\hline Feuerbach & Marx \\
\hline Essence humaine & Essence réelle (effective) \\
\hline Individu & Rapports sociaux \\
\hline Genre & Histoire \\
\hline
\end{tabular}

Si, pour l'instant, l'essence réelle de l'individu est une essence pratique qui est modifiée par les rapports sociaux dans le cadre historique, dans L'Idéologie allemande l'Histoire prendra la direction des affaires humaines en compagnie des rapports sociaux, ces derniers étant subsumés dans celle-ci.

\subsection{La condamnation finale de Feuerbach}

La thèse 7, une phrase unique, prolonge la thèse précédente, elle en est l'effet et l'exemple. Parce que Feuerbach se concentre sur l'essence humaine de l'individu générique, mais isolé, il ne peut rendre compte du canevas des interactions de la réalité sociale.

\section{" Thèse VII}

C'est pourquoi Feuerbach ne voit pas que le 'sentiment religieux' est lui-même un produit social et que l'individu abstrait qu'il analyse appartient à une forme de société bien déterminée. »31

La conception des rapports entre les hommes que soutient Feuerbach correspond à un déplacement à l'intérieur de la communauté des sujets de sa conception des rapports de l'homme à la nature : I'homme est à la société comme à son milieu. L'interaction sociale feuerbachienne ne relève pas d'une matrice socio-historique variable mais d'un donné anthropologique apriorique qui précède l'expérience. Pour Feuerbach, selon l'analyse qu'en fait Marx, le rapport entre hommes se définit comme un rapport socialement indifférencié ("union du Moi et du Toi »). La communauté humaine ne se manifeste pas sous l'angle des rapports sociaux qui la constituent. Elle apparaît au contraire dans sa dimension de configuration statique, comme lien naturel entre représentants de la même espèce. Sans être contraint par l'obligation théorique de relire la socialité " par en bas », en partant de l'action des sujets et des rap- 
ports sociaux, l'anthropologisme générique de Feuerbach pose la question surannée du rapport individu/espèce. Ce rapport considère l'homme comme réalisant son essence uniquement s'il vit conformément à sa nature générique, sans se soucier des procès réels de production sociale du sujet-acteur dans sa vie quotidienne.

Feuerbach admet toutefois qu'une rupture, un décalage peut avoir lieu entre essence générique et existence matérielle. Ce décalage rend manifeste pour Feuerbach un cas malheureux et marginal d'irrégularité dans l'ordre naturel du monde. II se manifeste dans le domaine "intellectuel » quand l'homme, par la religion, projette en Dieu ses propres caractères, quand il s'aliène en un être suprême et transcendant. Mais même s'il estime qu'une critique du "sentiment religieux » ne suffit pas à éradiquer les causes de l'aliénation ${ }^{32}$, Feuerbach ne fait pas mention des causes sociales de l'apparition du fait d'aliénation.

Ce faisant, Feuerbach ne peut rendre compte du canevas des interactions de la réalité sociale en se concentrant sur l'essence humaine de l'individu générique isolé. En ignorant l'historicité et la socialité essentielles de l'homme et de chacune de ses activités, Feuerbach tente le tour de force d'isoler dans un individu anhistorique, l'essence ou la nature humaine en général. Cet isolement conceptuel se double d'un isolement géographique puisque Feuerbach déploie naturellement son analyse sur des individus qui appartiennent à une formation sociale déterminée : les allemands de son époque ${ }^{33}$. Dans ses Thèses, Marx préfère affronter ce problème par le biais du rapport social et non anthropologique. L'essentiel de la proposition théorique et méthodologique marxienne réside ainsi dans le regard sociohistorique porté sur le procès d'émergence des déterminations qui canalisent la liberté d'action.

\section{Thèses $8,9 \& 10$ : de l'ancien au nouveau matérialisme}

Séparer les thèses huit, neuf et dix les unes des autres eût équivalu à scinder en trois phases successives et distinctes un mouvement unique qui voit Marx passer de l'affirmation de la praxis à la formulation expresse d'un " nouveau matérialisme » en substituant aux orientations intuitives-contemplatives de Feuerbach un matérialisme de la pratique collective.

\subsection{Une vie sociale pratique}

De l'essence sociale constituant l'homme, Marx passe à l'affirmation de la praxis comme possibilité de connaissance du monde dans la mesure où l'essence de la vie sociale réside dans la pratique. Or, cette pratique, outre le fait de se constituer socialement, s'avère intelligible, c'est-à-dire rationnellement appréhendable.

\section{"Thèse VIII}

Toute vie sociale est essentiellement pratique. Tous les mystères qui entraînent la théorie vers le mysticisme trouvent leur solution rationnelle dans la pratique humaine et dans la compréhension de cette pratique. ${ }^{34}$

(32) Feuerbach a bien insisté sur le fait que l'aliénation religieuse était le plus souvent volontaire, c'est-à-dire aliénation de soi par soi. Cf. Supra. Cf. Yannis Constantinidès, Le véritable opium du peuple in Karl Marx, Le nouvel observateur, Hors-série, Paris, oct-nov 2003, p.46.

(33) Le " germano-centrisme » est également de rigueur chez Marx.

(34) TsF [1845] in PI III, p.1033. 
Cela signifie que la rationalité humaine - lorsqu'elle est parvenue à se libérer du carcan de l'idéalisme et du mysticisme qui l'entravait - établit le lien entre la connaissance, la théorie et la pratique. Alors que, dans les thèses précédentes, la pratique, le social et la connaissance n'étaient pas mis directement en relation, ils apparaissent maintenant imbriqués. La définition du projet de Marx s'établit par la rencontre d'un macrocosme pleinement social, d'une capacité d'agir et d'une attitude cognitive qui se recoupent mutuellement. L'interconnexion de ces trois dimensions montre, par conséquent, l'irréductibilité des processus d'attribution du sens à un paradigme apriorique qui ne tiendrait pas compte des spécificités locales et autres facteurs contextuels (statut des sujets, culture, enjeux, intérêts, etc.).

Il est alors possible de localiser au cœur de l'espace social le sujet de la formulation d'une théorie de la connaissance. Or, dans la mesure où le sujet de la connaissance s'identifie aussi (ou devrait s'identifier) au sujet de l'action, le réel dont il parle se superpose au réel sur lequel il agit. L'acteur se manifeste comme le foyer qui énonce la connaissance, c'est-à-dire qu'il est le lieu d'une vérité socio-historiquement relative. Action et connaissance, praxis et savoir vont de pair en fondant le projet d'une décompartimentation des tâches. A l'acteur, Marx demande d'asseoir son action sur la connaissance, la compréhension - et non la théorie - tirée de la confrontation avec la vie réelle.

Le renversement feuerbachien consistait à substituer l'intuition à la pensée, alors que Marx substitue I'action à l'intuition elle-même. Être, pour l'action, cela veut dire agir. L'hétérogénéité ontologique structurelle de l'intuition et de l'action portée par Marx à l'évidence et pensée par lui dans le renversement s'explicite alors ainsi : agir ce n'est pas intuitionner, ce n'est pas voir, ce n'est pas regarder. Pour autant que l'intuition se produit, pour autant que nous vivons en elle, pour autant que nous " intuitionnons ", nous n'agissons pas. L'action considérée en elle-même n'a rien à voir avec ce regard de l'intuition, avec la découverte d'un spectacle, avec l'apparition d'un objet. Découvrir un spectacle, le contempler, vivre en présence de l'objet, c'est précisément ne pas agir.

L'action n'est donc possible que pour autant qu'elle n'est pas intuition, qu'elle n'est ni l'intuition d'elle-même ni celle d'un objet quelconque. C'est là ce que signifie la contingence de la relation de l'intuition et de l'action : une exclusion réciproque. Leur essence est totalement étrangère. En analysant l'intuition, c'est-à-dire l'apparition d'un objet, on ne peut y trouver l'action, mais seulement son contraire, le voir, la contemplation. De la même manière en analysant l'action, on ne peut y trouver l'intuition puisque si l'intuition était présente en elle, elle n'agirait pas. Marx élève le phénomène de l'action, de la pratique, parce que l'action n'est possible, n'agit, que pour autant qu'elle n'est pas une intuition, qu'elle n'a ni objet, ni monde. En somme, la praxis en vient à fonder l'être social en particulier, et l'être en général. Ce qui est à l'œuvre dans ces Thèses, comme le prétend M. Henry35, c'est le renversement de la philosophie occidentale elle-même via le renouvellement le concept de subjectivité.

\subsection{Contre un matérialisme contemplatif}

La praxis apparaît comme le lieu de constitution du sens. Du moment où le réel tout court devient le réel-dont-on-dit-la-vérité, l'objet perd son abstraction au profit d'une épaisseur de signification pour le sujet-producteur de sens qui l'énonce. Le matérialisme contemplatif de Feuerbach ne peut dépasser le point de vue de l'intuition faute d'avoir conféré au préalable à la réalité sociale une dimension historique. II empêche de saisir la société comme telle ainsi que son mouvement d'autopoïèse ${ }^{36}$. 


\section{« Thèse IX}

Le résultat suprême auquel parvient le matérialisme contemplatif - c'est-à-dire le matérialisme qui ne conçoit pas le sensible comme activité pratique, c'est la théorie des individus isolés et de la société bourgeoise. »37

L'importance décisive des Thèses sur Feuerbach vient de ce qu'elles apportent la réponse à la question qui meut depuis le début la réflexion philosophique de Marx, la question à vrai dire de la philosophie elle-même : qu'est-ce que la réalité ? Une réflexion radicale sur Feuerbach amène Marx à cette conclusion que dans I'hégélianisme la réalité est perdue. La réalité est perdue quand on lui substitue partout la pensée, quand les déterminations idéales de l'être résorbent en elles l'être lui-même. C'est l'étant au contraire que nous livre l'intuition de Feuerbach, et le matérialisme désigne cet étant comme irréductible au procès de la pensée qui le pense, comme hétérogène aux déterminations catégoriales de la conscience théorique qui le constitue justement comme l'ensemble de ces déterminations, comme un objet scientifique.

Mais avec les Thèses sur Feuerbach, l'intuition elle-même, comme pouvoir de recevoir comme objet l'étant qu'elle ne crée pas, est mise en question et à vrai dire récusée dans sa prétention à constituer la structure originelle de l'être. L'extériorité, et par suite l'être sensible, ne peuvent plus définir l'être luimême dans sa nature originelle. Ils ne peuvent plus définir la réalité. La réalité n'est pas la réalité objective. Ici se découvre à nous la signification abyssale de la pensée de Marx en tant qu'elle n'est plus la critique de la pensée mais celle du monde sensible, en tant qu'elle écarte maintenant le " matérialisme contemplatif ", selon l'expression même de Marx.

\subsection{L'humanité sociale}

Marx substitue ainsi à l'ancien matérialisme le projet d'un matérialisme nouveau qui prend en compte "la société humaine » ou "l'humanité sociale », marquant par cette inversion l'identité homme-société.

\section{« Thèse $X$}

L'ancien matérialisme se situe au point de vue de la société bourgeoise. Le nouveau matérialisme se situe au point de vue de la société humaine, ou de l'humanité sociale. »38

Le « matérialisme intuitif » de Feuerbach qui continue la tradition du matérialisme ancien (de Démocrite à Diderot et d'Holbach) ne suffit plus. Ce matérialisme interprète abusivement tout processus de connaissance à partir du critère immuable d'une nature primordiale, d'un état de fait originaire, l'humanité étant une nature abstraitement déterminée. Le matérialisme feuerbachien a, par conséquent, cessé d'être adapté au développement de la connaissance sur l'être en particulier. Le " nouveau matérialisme » sur lequel Marx s'appuie au contraire est un matérialisme pratique qui exprime et organise la transformation du monde, c'est-à-dire de la réalité naturelle et sociale, à partir de l'homme qui appartient au champ des rapports sociaux sans en être l'esclave. On mesure ici toute la différence avec le Matérialisme historique à venir. De son côté, l'identité homme-société marque également le refus (idéaliste) répété de Marx de toute médiation à l'intérieur de cette société39.

(37) TsF [1845] in PI III, p.1033. Labica, Bensussan et Lefebvre traduisent " matérialisme intuitif " au lieu de " matérialisme contemplatif » Cf. G. Labica, Karl Marx : les "Thèses sur Feuerbach ", PUF, Paris, 1987, p.20.

(38) TsF [1845] in PI III, p.1033.

(39) Déjà dans le M43, Marx critiquait Hegel pour avoir artificiellement posé des intermédiaires entre le monarque et la société civile (bureaucratie, Stände, etc.). Cf. S. Mercier-Josa, Retour sur le jeune Marx, Philosophie Meridiens Klincksieck, Paris, 1986. 
A travers la "société civile ", ce n'est pas seulement à Feuerbach que s'adresse Marx, mais aussi à luimême, i.e. à l'auteur de la Critique de la philosophie politique du droit qui fut son premier travail théorique. Ce refus de tout intermédiaire entre l'individu et son destin - l'histoire - caractérisait la première (figure de l'État-peuple) ainsi que la seconde philosophie de Marx (liaison directe entre la nature et l'homme) ${ }^{40}$. Les Thèses sur Feuerbach ne sont, en la matière, qu'une réminiscence de ces deux premiers moments car la troisième philosophie marxienne fera, avec l'apparition du Matérialisme historique, de l'intermédiaire, à savoir la classe - bourgeoise et surtout prolétarienne - le personnage principal de l'histoire mondaine, reléguant, de ce fait, l'individu privé au rôle de personnage secondaire. Pour autant, ce refus des médiations restera présent chez Marx car sa position sur l'utilité du parlementarisme et des élections sera ambiguë. II leur préférera souvent une hypothétique communion avec le prolétariat, figure hypostasiée de l'exploitation. Cette communion amènera la révolution qui abolira toutes les différences, toutes les séparations, de manière horizontale, entre les hommes et, de manière verticale, entre les individus et l'État. Tournant le dos à toute une tradition d'écrits politiques démocratiques traitant de la nécessaire représentation parlementaire ainsi que de l'obligatoire séparation des pouvoirs, Marx laisse entrevoir le caractère naïf de son « nouveau matérialisme ».

Pour le moment, le nouveau matérialisme marxien adopte un système conceptuel qui relie à la base ses trois piliers : la société des hommes, leurs connaissances et surtout - ce qui manquait à Feuerbach - leur pratique ${ }^{41}$.

\section{Thèse 11: Changer le monde}

La dernière thèse laisse deviner un programme social, politique et théorique découlant logiquement de l'opérationnalisation des acquis des thèses précédentes.

\section{« Thèse XI}

Les philosophes n'ont fait qu'interpréter le monde de diverses manières ; ce qui importe, c'est de le transformer. »42

Les Thèses sur Feuerbach s'achèvent sur une injonction à l'action. Cette dernière exprime le projet d'éradication de tout idéalisme stérile et la promotion de la praxis que véhicule le nouveau matérialisme marxien. Cet impératif catégorique deviendra la devise qui animera le travail de Marx les quarante prochaines années de son existence. De ces années, nous connaissons le début, mais pas lui. Marx n'a pas encore fait les choix qui vont influer directement sur toute son œuvre. C'est pourquoi il nous faut comprendre ce que Marx peut bien vouloir dire, tout en se gardant d'anticipations intempestives trop aisées à faire.

Comme d'autres avant lui, Marx appelle à une réforme de la philosophie. Après lui, d'autres lanceront le même appel. Comme ses prédécesseurs, Marx ne manque pas de critiquer ceux qui l'ont précédé. Parmi les philosophes visés, Marx inclut, bien évidemment, Feuerbach et Hegel. Selon lui, Hegel appartient à ces philosophes qui se sont contentés de penser le monde ${ }^{43}$, c'est-à-dire de proposer une interprétation de ce qui est (i.e. doit être, selon la vision que Marx se fait de la philosophie hégélienne) et devient, précisément une philosophie de la nature, de l'histoire, du droit, de l'art, de la religion, etc. Au contraire, la question posée par Marx est celle de la pratique. Cette question substitue à la téléologie traditionnelle du savoir théorique celle de l'action, impliquant non plus la reconnaissance des lois de l'Être, mais les modifications radicales qu'il devait subir - le savoir, la connaissance ne pouvant plus qu'être subordonnés à cette finalité par essence " pratique ».

(40) Cailleba, Ibidem

(41) Selon M. Rubel, ce " nouveau matérialisme " se propose comme la nouvelle praxis, dont il est au même titre la théorie au double sens de critique de l'existant et d'intuition rationnelle du futur. Ce n'est ni un matérialisme « historique » ni un matérialisme " dialectique ». N'importe quelle sorte de "marxisme » se trouve de ce fait condamnée d'avance et sans appel. Ayant failli au devoir de respecter cet interdit, selon M. Rubel, Engels a fini par assumer malgré lui le rôle ambigu de "fondateur » (in PI III, p.CXXII sq.).

(42) TsF [1845] in PI III, p.1033.

(43) Proposition que l'on peut remettre en doute s'il est vrai que l'hégélianisme n'est pas une philosophie de la pensée mais précisément de l'action, une philosophie qui dit: "Das Wesen des Menschen ist die Arbeit » (l'essence de I'homme est le travail). Cf. Supra. 
En fait, quand on oppose la Xlème thèse - la critique de toute philosophie - à l'hégélianisme, on ne doit pas oublier que Hegel l'a déjà écrite, et cela non pas de façon incidente, mais lorsqu'il a voulu livrer le fond de sa pensée :

"Pour dire encore un mot sur la prétention d'enseigner comment le monde doit être, nous remarquons qu'en tout cas la philosophie vient toujours trop tard. En tant que pensée du monde, elle apparaît seulement lorsque la réalité a accompli et terminé son processus de formation (...) C'est dans la maturité des êtres que l'idéal apparaît en face du réel (...) L'oiseau de Minerve ne prend son vol qu'à la tombée du jour. »44

Cependant pour Hegel, l'action porte en elle l'essence de la conscience de soi et ouvre l'espace de la pensée : elle ne se sépare pas de celle-ci. II n'y a dans l'hégélianisme aucune différenciation radicale entre les diverses modalités de l'existence, entre l'action, la pensée, le langage, l'art, etc. Dans la pensée hégélienne, il s'opère une substitution de la conscience à l'action. L'action se développe comme conscience de l'objet et comme voir, établit celui-ci au sein même de l'action, libère en elle la place de la pensée.

"La conscience de soi qui purifie son objet, son contenu et son but et qui l'élève à cette universalité, agit comme pensée s'établissant dans la volonté. Voilà le point où il est évident que la volonté n'est volonté que comme intelligence pensante. » ${ }^{45}$

Marx, quant à lui, rejette à la fois l'intuition de Feuerbach et l'action de Hegel. II le fait, non par hasard dans la simple coïncidence chronologique de deux mouvements de pensée différents, mais dans l'unité d'un seul mouvement, qui renverse conjointement l'intuition sensible et l'action de la pensée, le matérialisme et l'idéalisme, parce qu'il renverse l'unique essence qui les habite l'un et l'autre, l'essence de l'objectivation, l'essence de la théorie. Marx reprend ainsi différemment un couple conceptuel dont il avait déjà fait mention dans la seconde thèse : I'opposition entre intuition-contemplation et changementtransformation. II condamne ainsi l'ancien matérialisme qui passait l'histoire sous silence. Feuerbach ne tenait pas compte en effet du devenir des sociétés. II ne tenait pour vrai que la réalité objective dans sa manifestation synchronique.

Au-delà de l'ancien matérialisme qui permettait de dépasser dans la pensée l'aliénation religieuse ${ }^{46}$, l'auteur des onze Thèses vise un dépassement dans la réalité empirique des conditions de production sociale de l'aliénation en général. C'est pourquoi sa version du matérialisme contient une dimension éthique forte et préconise le changement du monde afin de faire coïncider l'essence sociale de l'homme à son être mondain. Chez Marx, l'action donne effectivement le sens et non l'inverse. Ce faisant, elle est le fruit d'une démarche éthique permettant :

- de dégager un universel pour moi qui soit autre chose qu'un invariant absolu,

- de fonder radicalement la possibilité d'une critique sociale.

Définitivement, pour Marx, admettre l'existence et l'importance de conditionnements sociaux, même profonds, qui délimitent le champ des compossibles de l'action ne peut signifier ni une élimination théorique de la responsabilité et des stratégies actorielles du sujet, ni une mise à l'écart pratique des composantes anthropologiques du comportement.

Ainsi le rejet de l'aliénation humaine (entrevue à travers l'aliénation religieuse dans ces onze Thèses) doit-il passer par une critique et par une transformation de la configuration des rapports sociaux caractéristiques de son apparition 47 . La onzième thèse clôt le parcours théorique par une proclamation programmatique de changement de la société qui se fixe pour objectif d'abolir à la fois les anciens rapports sociaux, l'aliénation à laquelle ils conféraient une stabilité et le matérialisme intuitif-contemplatif qui les discernait dans leur réalité mondaine mais synchronique.

(44) Hegel, Principes de la philosophie du droit, Préface, préface de Jean Hyppolite, Gallimard, collection Tel, Paris, 1989.

(45) Hegel, Phénoménologie de l'Esprit, trad. J. Hyppolite, tome I \& II, Paris, éd. Aubier, 1949, réed. Aubier-Montaigne, 1967, réédition 1989, tome I, 21.

(46) Ludwig Feuerbach, "Thèses provisoire pour la réforme de la philosophie“ in Manifestes philosophiques, P.U.F., textes choisis (1839-1845) et traduits par Louis Althusser, 1973, p. 107, thèse 13.

(47) Néanmoins le contenu de la Thèse XI demeure à bien des égards équivoque. Tout se passe en effet, selon la lettre de cette thèse, comme si l'histoire de l'humanité se divisait en deux périodes, la première durant laquelle les philosophes ont pensé le monde, la seconde, qu'il convient maintenant d'inaugurer et qui serait celle de sa transformation. On a tout lieu de croire que les hommes ont transformé le monde depuis qu'ils l'habitent, depuis des millions d'années et que la pensée du monde ou "philosophie » est, elle, fort récente. 
L'originalité qu'introduit cette ultime thèse consiste dans le changement de statut qu'elle opère de la philosophie et de la pensée en général moyennant la modification imposée à sa base matérielle. A ce titre, les Thèses se détachent comme une pièce majeure de l'aggiornamento théorique des thématiques de Marx par rapport aux cadres d'investigation privilégiés avant 1845. En effet, Marx réfute ici toute philosophie exclusivement spéculative. II soutient une version de la philosophie qui est équivalente à une théorie pratique et à une pratique de la théorie ${ }^{48}$. Pratique et théorie restent en fait inséparables dans le mouvement même qui invite à les dissocier.

Le monde ne doit plus, pour Marx, demeurer dans son état actuel, il est indispensable de le changer. Le principe de la pratique ne souffre pas d'exception : connaître le monde constitue une activité indispensable mais le connaître et le changer, le connaître pour le changer, et le changer effectivement, voilà I'indication programmatique que Marx propose ${ }^{49}$. La prétention de ce projet à dépasser la philosophie par un retour aux conditions matérielles d'existence et aux conflits qui les traversent implique le refus de tout discours sur les hommes en général et sur le genre humain à l'avantage d'une reconduction du sujet à son appartenance sociale ${ }^{50}$.

L'Idéologie allemande donnera un sens particulier à la Thèse $X I$ en prononçant la fin d'une certaine philosophie. Le cadre de la réflexion sera alors entièrement différent. Pour le moment, au printemps 1845 , pour l'auteur des Thèses, la philosophie qu'il condamne amplement dans son opuscule, a une utilité pratique et donc théorique assez réduite. Elle n'extraie rien ou si peu de sa relation avec le monde car elle n'entretient aucune espèce de rapport avec lui. Elle « est à l'étude du monde réel ce que l'onanisme est à l'amour sexuel »51.

(48) Pierre Bourdieu (avec Loïc J. D. Wacquant), Réponses, Coll. "Libre examen ", Seuil, Paris, 1992, p.97. Marx use clairement, dans ses Thèses, du vocabulaire classique de la philosophie pour désigner une autre discipline qui ne relève plus de ce champ traditionnel, mais qui s'inscrit davantage dans l'effectivité des rapports sociaux en tant que démarche sociologique à laquelle se superpose le jugement éthique.

(49) Et à laquelle, puisque pratique sociale et socialité de l'existence sont liées, nul ne peut se soustraire. Cf. Pierre Bourdieu, La distinction, Les Editions de Minuit, coll. "Le sens commun », Paris, 1979, p.544-545.

(50) Nous verrons plus loin que, à partir de $I A$, l'appartenance sociale à un groupe redeviendra prépondérante et que la transformation du monde ne sera l'affaire que d'une partie de l'humanité, le prolétariat (et non de la « multitude » comme l'écrit M. Rubel - in PI III, p.1021 -, ou, ce qui est encore moins vrai de "l'immense majorité », puisque le prolétariat n'est pas majoritaire).

(51) $\quad I A$ in $P I I I I$, p.1200. 


\section{Conclusion}

A l'exception de certains fragments des pré-socratiques, le texte de Marx, Ad Feuerbach ${ }^{52}$, est le document le plus court de notre tradition philosophique occidentale. II s'agit, en effet, de deux pages et demie qui comptent 65 lignes réparties en 11 notes dont la dernière - la plus commentée - compte à peine une ligne et demie. Malgré cette brièveté, nous tenons le jugement de L. Goldmann, cité par G. Labica, pour entièrement fondé :

" (...) [leur] importance historique est du même ordre que celle du Discours de la méthode, de la Critique de la raison pure ou de la Phénoménologie de l'esprit. ${ }^{53}$ »

Au delà de l'analyse que nous venons d'en proposer, Marx a su donner à ses Thèses l'évidence de la vérité brute, tirant leur force de la concision de l'expression. Chaque thèse repose, en effet, sur un antagonisme qui fonde l'aphorisme. Et, pour ce faire, Marx a emprunté à Feuerbach le procédé qui consiste à produire un clivage, une opposition (par exemple Ciel-Terre). II a ainsi donné aux Thèses la scène qui leur permet de clamer en tout lieu et toute époque leur vérité.

- thèse I : intuition / activité ;

- thèse II \& V : pensée / pratique ;

- thèse III : circonstances / éducation ;

- thèse IV : monde religieux / monde profane ;

- thèse VI : essence religieuse / essence humaine ;

- thèse VII : individu / forme sociale ;

- thèse $X$ : société civile bourgeoise / société humaine ou humanité sociale ;

- thèse $\mathrm{XI}$ : interpréter / transformer.

Chez Feuerbach, ce clivage sert à faire entendre, à la fois, qu'il n'a pas de raison d'être (Ciel et Terre ne sont pas séparés) et que le vecteur qui les unit est inadéquat (on ne conclut pas du ciel vers la terre, mais inversement). De même, chez Marx, théorie et pratique sont également liées, unies, sans jamais être séparées. Toutefois, à la différence de Feuerbach, il n'y a pas de relation directe de la théorie vers la pratique, même si on accorde plus d'importance à la pratique par rapport à la théorie. La fameuse thématique du "renversement » [Umkehrung], du " monde à l'envers » [die verkehrte Welt] ou de "la tête en bas " [auf dem Kopf] trouve là son origine. Marx use, de la sorte, de cette matrice explicative tout au long de ces Thèses où il confère, à cette structure duelle, une unité pugnace.

Ainsi en va-t-il de ces « notes » comme des fragments d'Héraclite, des aphorismes de Nietzsche ou des carnets intimes de Valéry : le lecteur découvre dans l'apparente spontanéité d'un esprit pensant une invitation à la libre co-production du sens. D'où la polysémie des interprétations (dont B. Andreas s'est fait l'écho54) et l'intention programmatique qu'on a voulu y déceler sur le reste de la philosophie marxienne en pensant, faussement, que son œuvre ultérieure (du Manifeste jusqu'au Capital) prenait son départ, plongeait ses racines dans ces Thèses. De fait, une autre explication à leur postérité serait la suivante : après les Thèses sur Feuerbach, Marx n'élaborerait aucune autre nouvelle philosophie. Les Thèses constitueraient donc la première trace en même temps que l'ultime acquis théorique vierge de toute compromission ultérieure, propres à susciter l'admiration et l'exégèse des intellectuels, puisque Marx ne ferait, par la suite, qu'approfondir certains points en en affaiblissant d'autres, à savoir en mettant en œuvre, dans son œuvre, l'impératif éthique de son ultime thèse. Cette idée est séduisante car, au regard du temps, quelques semaines à peine séparent les Thèses de L'ldéologie allemande. Mais après notre analyse, elle est fausse car, une fois refermé le cahier qui les contient, Marx posera réellement les bases d'une nouvelle philosophie dont les axiomes prendront le contre-pied des Thèses.

(52) II ne s'agit pas de Thèses au départ pour Marx - la dénomination ne viendra que plus tard - puisqu'il intitule, dans ses cahiers, le fruit de ses méditations "Ad Feuerbach".

(53) G. Labica, Karl Marx : les "Thèses sur Feuerbach », PUF, Paris, 1987.

(54) Bert Andreas, Das Ende der klassischen deutschen Philosophie, Bibliographie, Trier, Karl Marx Hauss, 1983. 
En outre, le caractère laconique des Thèses laisse courir des zones d'ombre dans leur interprétation. Qui doit opérer la transformation de la Thèse XI ? Qui doit faire l'éducation des hommes (Thèse III) ? Et ce, comment? A qui s'adresse réellement Marx ? Qu'entend-il par homme ? Si l'essence humaine est l'ensemble des rapports sociaux, quid du libre arbitre individuel (Thèse $V I I$ ) au sein d'une forme sociale déterminée ? N'y a-t-il pas d'autres aliénations que l'aliénation religieuse (Thèse IV \& VII) ? Qui doit réaliser cette " praxis révolutionnaire " qu'il semble appeler de ses vœux (Thèse I) ? Que comprend-il exactement par là ? Qu'en est-il enfin de "l'humanité sociale » et de la "société humaine » (Thèse X) ? Une forme de communisme? Mais pourquoi ne l'écrit-il pas tel quel ?

La transformation mise en avant dans la Thèse $X I$ a pour écho l'auto-transformation. Cette dernière est le processus de la révolution, du changement, toujours à l'œuvre dans la pratique. La conscience que I'on en prend est ipso facto auto-éducation. L'idée de l'auto-émancipation du prolétariat retrouvera là une nouvelle origine. Pourtant, si le thème du prolétariat est déjà apparu dans l'œuvre marxienne (il est présent dans les deux premiers moments)55, il reste étonnement absent des Thèses sur Feuerbach. G. Labica souligne l'absence du mot "idéologie » dans les Thèses sur Feuerbach. Cela l'amène "à se demander s'il ne surgit pas précisément dans l'étroit espace des quelques mois compris entre les Thèses et $L^{\prime} / d e ́$ ologie allemande »56. S'il est vrai que le concept a pu précéder sa stricte dénomination, tout comme celui d' "Histoire » ou de "lutte des classes » qui n'apparaissent qu'après 1845, cela ne laisse pas de nous interroger sur les raisons de l'absence d'autres concepts tout aussi fondamentaux, mais plus nombreux, tels que " classe ", " prolétariat ", "bourgeoisie ", "Révolution ", " communisme », " socialisme » ou encore " aliénation » (et non simplement " aliénation religieuse ») qui, au contraire de "l'idéologie » ou de la "lutte des classes », faisaient déjà partis du vocabulaire marxien en 1845.

Pourquoi Marx n'y fait-il pas référence dans ses Thèses sur Feuerbach ? Si Marx avait voulu mettre sur papier ses pensées sur ces thèmes, les Thèses auraient été le meilleur des endroits pour rassembler les vérités auxquelles il était parvenu. Pourquoi ne l'a-t-il pas fait ? Nous faisons l'hypothèse suivante : les onze apophtegmes sur Feuerbach sont autant de sentences que Marx considérait entièrement vraies au printemps 1845. Et uniquement celles-ci. Ils sont la matérialisation de ce que Karl Marx, adolescent, avait écrit à son père, l'examen philosophique que le jeune philosophe porte " avec le regard d'aigle de la pensée ${ }^{57}$ sur les vérités auxquelles il est parvenues à l'aube de ses 28 ans. Les thèses constituent une forme de bilan intellectuel pour leur auteur lui-même.

Si Marx n'a pas fait état des autres concepts qu'il avait déjà entrevus (et que la postérité retiendra comme la substance de l'œuvre marxienne), la raison est certainement qu'il ne croyait pas, à ce momentlà, c'est-à-dire une fois que l'idéalisme feuerbachien lui soit apparu clairement à l'esprit, que l'existence du prolétariat et de la bourgeoisie, la présence de classes et le phénomène de l'aliénation en général (et non pas seulement l'aliénation religieuse), etc., constituaient des vérités absolues.

Nous appuyons cette hypothèse par la suivante : I'utilisation de la praxis au sein de ces Thèses devait permettre de pallier la résurgence de ces concepts. Qu'est-ce à dire ? Dans notre étude des Thèses, nous pensons avoir montré que quelque chose ressortant d'une volonté libre perdure au travers de la praxis. Cette volonté libre s'exprime d'ailleurs avec force et détermination en conclusion dans la Thèse XI. En fait, la praxis ouvre la porte à une liberté individuelle réelle qui court depuis la première jusqu'à la dernière Thèse. De la sorte, il n'y a plus de place pour des concepts qui interdisent ou limitent grandement la praxis - cette dernière souffrant déjà d'une certaine finitude qui demeure toutefois limitée. 
Cependant, de l'ambiguïté viscérale du concept de praxis, Marx tirera peut-être une des raisons pour abandonner progressivement ce concept flou en lui préférant les concepts qui la manifestent directement dans un cadre économico-social beaucoup plus contraignant comme " production matérielle ", "lutte des classes ", etc. Alors, les rapports sociaux qui, dans les Thèses sur Feuerbach, n'avaient pas définitivement le droit à l'existence et qui voyaient l'action de la pratique leur être en quelque sorte extérieure, constitueront, dans L'ldéologie allemande et l'œuvre ultérieure, la véritable pratique. Et la pratique constituera, à son tour, leur Selbstveränderung. Ainsi, avec l'effacement du concept de praxis et la réapparition de vocables tels que " production ", "révolution », " aliénation », " classes ", disparaîtra parallèlement toute forme de liberté individuelle et se fermeront sur l'individu les portes ouvertes par les Thèses 58 .

D'aucuns objecteront que les concepts-clés de la philosophie marxienne ci-dessus évoqués ne sont que le prolongement, les conséquences logiques de ces Thèses. II s'agirait alors d'une suite avec de nouvelles Thèses que I'on pourrait numéroter XII, XIII, XIV, etc. L'explication serait alors simple : il est normal que ni le prolétariat, ni la bourgeoisie, ni la production, etc. ne soient présents dans ces Thèses puisqu'il n'y a pas de places pour elles. Elles n'ont de relation avec les Thèses « primordiales » que sur le plan de la déduction des onze premières lois de la Table marxienne. D'un côté la Torah, la loi originale, de l'autre le Talmud, le commentaire et l'interprétation.

Pourtant, tous les concepts évoqués auraient eu leur place dans les onze premières thèses. Par exemple, le phénomène global de l'aliénation se situe dans la continuité de l'aliénation strictement religieuse (Thèse IV et VII). Lorsque Marx parle de " produit social » en pointant le manque de perspicacité de Feuerbach dans son analyse matérialiste de l'aliénation religieuse, il pourrait faire cette critique en précisant la sienne, à savoir celle à laquelle il était déjà parvenu dans les Manuscrits de 1844 et dans son Introduction à la Critique de la philosophie du droit de Hegel en 1843, c'est-à-dire celle d'une aliénation généralisée.

De même, la bourgeoisie, comme le prolétariat, pourrait apparaître dans n'importe quelle Thèse. La Thèse III, en particulier, fait partie de l'une d'entre elles : le matérialisme "classique " divise artificiellement la société en deux parties alors qu'il faut engager une "pratique révolutionnaire » pour transformer les circonstances. Qui peut transformer les circonstances ? Qu'en est-il du prolétariat non cité ? S'il n'y a pas de référence faîte au prolétariat, cela signifie, par voie de conséquence, que tous les hommes peuvent s'engager dans la transformation des circonstances qui les forment et cela dans l'absence totale de révolution, sinon de "pratique révolutionnaire ». II ne peut en être autrement. Pourtant le concept de prolétariat est un concept-clé qui est déjà apparu timidement dans la première période et a pris pleinement place lors de la seconde période. Comment expliquer son absence?

En dehors du prolétariat, le concept de classe devrait pouvoir apparaitre en contrepoint dans la Thèse VI lorsque Marx traite des contraintes auxquelles Feuerbach s'est exposé dans la définition de son essence générique naturelle :

« Feuerbach est obligé (...) de ne concevoir l'essence que comme 'genre' (...) qui relie de manière naturelle la multitude des individus $» 59$

(58) M. Henry engage, à partir des $T s F$, toute sa lecture de Marx. D'un Marx qui serait parvenu au concept d'une «subjectivité radicale d'où toute objectivité est exclue ", d'une action qui " n'est possible, n'agit, que pour autant qu'elle n'est pas une intuition, qu'elle n'a ni objet, ni monde »; d'un Marx qui écarterait "l'intuition sensible de Feuerbach à l'aide de l'action de la pensée de l'idéalisme » et inversement; et d'une action qui ne peut être extraite de ce " cercle " que par la mise en question qui, selon Henry, " atteste en 1845 le maintien absurde de la terminologie et de l'ontologie de Feuerbach au moment même où Marx se donne explicitement pour but le renversement de cette ontologie " (M. Henry, Marx, tome I : Une philosophie de la réalité, Gallimard, Paris, 1976, réed. 1991, p.326 et passim). Le Marx que nous avons lu, surtout dans ses écrits postérieurs, ne semble pas avoir de ces audaces. Le réel, le monde sensible forment, certes, son horizon et sa visée, en même temps que l'activité-praxis son correctif. Cependant, tout cela, s'étiolera rapidement.

(59) $T s F[1845]$ in $P / I I I$, p.1032. 
Marx aurait pu aller alors plus loin en passant d'une humanité non-homogène, telle qu'elle ressort de la critique de Feuerbach, à la critique d'une humanité regroupée en classes et séparée par des intérêts opposés comme il l'avait déjà fait auparavant lorsqu'il partageait les hommes autour de la propriété privée : il y a ceux qui possèdent et il y a les autres. De plus, pourquoi, dans la Thèse $X$, Marx parle de " société-humaine » ou d'" humanité-sociale » alors qu'encore peu de temps auparavant, dans les Manuscrits de 1844, il utilisait avec force le terme de "communisme "60. La même question revient encore une fois : pourquoi ne parle-t-il pas de communisme et de tous ces autres concepts qu'il a déjà abordés?

Au travers de ces Thèses, nous pensons que Marx a voulu coucher sur le papier - pour son seul usage l'essence de sa philosophie, les réflexions philosophiques auxquelles il était parvenu et qu'il regardait comme fondamentales en même temps que dernières. Fondamentales parce qu'il s'agissait de poser les fondements, les bases de toutes activités politiques et philosophiques à venir. Dernières parce que Marx pensait avoir réussi à mettre en exergue, via la praxis, les axes structurants du processus d'une action humaine libre bien que toujours immergée dans un monde de relations sociales. Si, comme l'a écrit $D$. Howard, l'œuvre de Marx peut être considérée comme une "tentative de réalisation de la philosophie qui débouche alors sur une tout autre façon de philosopher " 61 , alors cette tentative a un nom, les Thèses sur Feuerbach, et un moment bref, la fin du printemps 1845.

(60) «Ce communisme (...) est la vraie solution du conflit (...) de l'homme avec l'homme, la vraie solution de la lutte entre l'existence et l'essence (...) 》 M44 [1844] in $\mathrm{Pl} / I$, p.79.

(61) D. Howard, 'Marx, philosopher autrement?' in Histoire de la philosophie politique, Tome 4 : Les critiques de la modernité politique, CalmannLévy, Paris, 1999, p.180. 


\section{Références bibliographiques*}

Marx K. (1977), đEuvres : Economie I, 2ème édition, Paris: Gallimard - La Pléiade

Marx K. (1968), Euvres : Economie II, Paris: Gallimard - La Pléiade

Marx K. (1982), Euvres : Philosophie, Paris: Gallimard - La Pléiade

Marx K. (1994), Guvres : Politique I, Paris: Gallimard - La Pléiade

Marx K., ENGELS, F. (1971), Correspondance - Tome I : novembre 1835 - décembre 1848, Paris: Editions

Sociales.

Pour la plupart des ouvrages de Marx, un certain nombre d'abréviations ont été retenues.

\begin{tabular}{ll}
\hline Guvres & Abréviations \\
\hline Thèse de doctorat sur la Différence de la philosophie naturelle chez Démocrite et chez Epicure & Thèse \\
\hline Critique de la philosophie du droit de Hegel & M43 \\
\hline A propos de la Question juive (Annales franco-allemandes) & QJ \\
\hline Introduction à la Critique de la philosophie du droit de Hegel (Annales franco-allemandes) & I-M43 \\
\hline Manuscrits de 1844 & M44 \\
\hline La Sainte Famille & LSF \\
\hline Articles pour le Vorwärts! & Vorwärts ! \\
\hline Thèses sur Feuerbach & TSF \\
\hline L'Idéologie allemande & IA \\
\hline Misère de la Philosophie & MPh \\
\hline Manifeste du Parti Communiste & MPC \\
\hline Les luttes des classes en France 1848-1850 & LdC \\
\hline Le 18 Brumaire de Louis Bonaparte & $18 B$ \\
\hline Introduction à la Critique de l'Economie Politique & I-CEP \\
\hline Principes d'une Critique de l'économie Politique & Grundrisse... \\
\hline Critique de l'Economie Politique & CEP \\
\hline Tous les opuscules où il est fait référence en titre à l'Association Internationale des Travailleurs & AIT \\
\hline Le Capital & Le Cap. \\
\hline La Guerre Civile en France & GCF \\
\hline Critique du programme du parti ouvrier allemand & Critique \\
\hline
\end{tabular}

Les citations sans nom d'auteur concernent toutes Marx. Les textes cités dans l'édition Rubel de la Pléiade sont notés PI suivi du numéro de volume (de I à IV en chiffre romain).

*Toutes les autres références sont présentes en notes de bas de page. 


\section{The Trinity of International Strategy: Adaptation, Standardization and Transformation.}

By Ali Yakhlef

School of Business, Stockholm University,

Stockholm, Sweden and

Groupe ESC-Pau, Pau, France 


\section{Abstract}

The significance of context has not escaped the attention of international strategy theorists. In entering foreign markets, firms are assumed to possess two choices: an adaptation to the context and/or a standardization strategy. A concern with adaptation or standardization would convey the idea that the context is given and management action is reduced to adapting or not adapting to it. Both such approaches downplay the role of management's ability to transform the context, as argued by many researchers from diverse disciplines. In order to redress this imbalance, the present paper seeks to emphasize the significance of a transformation strategy the main concern of which is not only to passively adapt to the foreign context nor to settle for a standardization strategy, but also to transform the context in the image of the home context.

Adopting a social constructionist approach, the paper argues that the context and content of strategy are intrinsically-bound up. Rather than just adapting or not adapting to the target context of the foreign market, it is contented that the extension of a strategy from one context to another entails or requires the transformation of that context. In illustrating this approach, the paper discusses the case of IKEA's extension of its strategy into the Chinese context. The paper closes with some implications for the theory and practice of international marketing strategy.

\section{Key words}

International strategy, adaptation; standardization; context; translation; participation; reification; transformation. 


\section{Introduction}

Research in the area of international business conjures up two dominant pictures of international marketing strategies: adaptation and standardization (Ryans, Griffith, and White 2003). There are as many advocates of adaptation as of standardization strategies as strategic devices for competing in overseas markets (Jensen and Szulanski 2005). The rationale for a standardization-driven strategy is greater market similarity, more technological uniformity, and higher convergence of consumer needs, economies of scale, tastes, and preferences, and, the emergence of global market segments, consistent corporate brand, reduction in managerial complexity, increased control, etc (Levitt 1983; Douglas and Craig 1986; Yip et al 1988;Theodosiou and Leonidou 2003). By contrast, adaptation to the recipient's context is regarded as a necessary condition for increasing acceptance of products, policies and practices by modifying them so as to befit local requirements (Bartlett and Ghoshal 1998; Almeida and Grant 1998; Gupta and Govindrajan 2000).

Champions of the adaptation strategy approach are sensitive to the specific requirements of local markets and country differences arising from consumer needs and their purchasing power, infrastructures, social, legal, and cultural contexts that require adjustment of the firm's marketing strategy to the idiosyncratic circumstances of each foreign market (Terpstra and Sarathy 2000). For these, a standardization approach glosses over the complexity of local markets, going against the grain of the marketing concept (Boddewyn and Grosse 1995, Wind and Douglas 1987). Standardization is only a matter of reducing costs, whereas a firm's concern is about long-term profitability through higher sales resulting from better exploitation of the different customer needs across countries (Boddewyn and Grosse 1995, Wind and Douglas 1987).

Mindful of the significance of the impact of context on strategic choices, the contingency approach argues that standardization or adaptation are not polar opposites, but are to be understood as forming a continuum of degrees of standardization and adaptation (Quelch and Hoff 1986; Onkvisit and J.J. Shaw 1987; Jain 1989; and Cavusgil, Zou and Naidu 1993). Whether to standardize or adapt the marketing strategy is dependent upon the contingency factors prevailing in a specific market at a specific time. The contribution of contingency theory to the debate is its recognition of how the context or the environment shapes corporations' strategies.

Insightful though these considerations may be, they overlook the power of corporate strategy to shape and transform their context or environment. Organizations are not shaped by their environment but also they are actively involved in shaping that very environment. For, over the past decades, researchers have increasingly paid attention to the manner in which organizations work to influence and transform their environments in which they operate (March 1981; Whittington 2006). While strategy is under the pressure of environmental factors and changes, at the same time it imposes certain change in that very environment (March 1981). Institutional researchers have also argued that the environment is partly created by organizational strategies (DiMaggio, 1988; Oliver, 1991). Researchers from such various areas as strategic management (Hamel \& Prahalad, 1989; Porter, 1991), entrepreneurship (Aldrich \& Fiol, 1994), and even organizational ecology (Baum \& Oliver, 1991), have recognized the fact that organizations actively participate in the social construction of their environments. Organizational environments are constituted, reproduced and transformed through organizational strategic actions.

Based on this literature, the present paper seeks to emphasise the transformative effect of international marketing strategy. Adaptation is a strategy that is accommodating, attempting to listen to the requirements of the market environment. Standardization is a non-listening strategy. In addition, a transformation strategy attempts to listen (adapt to local requirements), standardize (not to listen) but also to transform the environmental conditions so as to make these contextual conditions befit the firm's strategy. From this perspective, a transformative approach, while recognizing adaptation and standardization, complements the adaptation and standardization approaches. The assumption is that, when a given 
strategy is extended from its original context to a different context, the success of that strategy would also depend upon a firm's ability to change the target context, over and above its adaptation and standardization efforts.

This is the main argument of the present paper, namely that an emphasis on standardisation and adaptation tends to leave a gap in our understanding of international strategy. Given that the literature has largely dealt with adaptation and standardization strategies and that transformation has been neglected the present paper seeks to redress this imbalance by emphasizing the significance of a transformation strategy. Adopting a situated approach to strategy, the aim of this paper is 1) to argue that the extension of a marketing strategy from the home context to a foreign one entails the transformation of the target context (in however small way that may be), and 2) to explore the manners in which such transformative actions take place. As an illustration, the paper uses the case of IKEA, the world's largest home-furnishing retailer that has successfully established its operations, in many corners of the world, relying on a trinity of strategy: standardization, adaptation, and transformation - where transformation aims to change the many target contexts in the image of its original, Swedish context.

\section{Outline of the paper}

Section Two begins with a critical appreciation of the adaptation-standardization polarity, pointing out transformation as a complement to the two dominant streams of thought. Taking the contingency approach seriously implies that nothing is stable, even context is in constant mutation. The content of a global marketing strategy cannot be decoupled from the various contexts in which it is applied; nor can it only accommodate to all contextual variations. For that matter, transforming the contexts so as to befit the strategy is a crucially vital precondition for success. The assumption that the context is itself part and parcel of the content of the marketing strategy poses the pertinent question of how a business model or marketing strategy that has proved successful in one context can be found to function successfully in a different one. Section 3 will adopt a social-constructivist approach to highlight the interplay between content and context, drawing on ideas from the sociology of knowledge (Knorr Cetina 1981; Latour 1987; 1988; Longino 2002). Section 4 focuses on how contexts are transformed, suggesting the concept of translation (Callon 1986; Czarniawska, 1986; Latour 1987; 1988) as a transformation mechanism. The success or failure of an international marketing strategy is defined in terms of the extent to which the global player succeeds in transforming the institutional, cultural context in the image of the source context. Section 5 discusses the framework using as an example: the case of IKEA's extension of its operations in China. One the one hand, IKEA is struggling to impose its standardized marketing strategy and design style on Chinese consumers. It is also actively engaged in transforming many of the contextual features which, if they do not change, would be a threat to its strategy, on the other. The case provides ample evidence that speaks for how strategies have a transformative effect on their environment. Organizations are the product of, but also produce, their environment. Finally, the paper closes with some implications of this approach for our understanding of international marketing strategies. 


\section{International Marketing Strategy: to Adapt to or to Standardize}

As noted above, the contingency approach assumes that what marketing strategy a firm would adopt is contingent upon a number of contextual factors. Such contextual factors relate to all the background forces that impact the firm's decision to choose a standardization or adaptation international marketing strategy. Conventionally, these contextual factors are grouped into environmental, market, customer, competition, product I industry, organizational, and managerial (Theodosiou and Leonidou 2003). Environmental factors are largely defined as the set of economic, socio-cultural, political-legal, and physical forces which impact directly or indirectly a firm's international business operations. However, in their review of the literature on the effect of environmental factors on strategy standardization or adaptation Theodosiou and Leonidou (2003) have found only 18 out 43 studies supporting this assertion. This is particularly the case for both product (e.g. branding) and pricing, thereby casting some doubt over the traditional notion that environmental factors alone can explain the dynamics of marketing strategy.

Another contextual contingency concerns the level of sophistication and development of a particular foreign market, such as its marketing infrastructure, advertising media availability, distribution structure, and market size (Theodosiou and Leonidou 2003). On this issue, researchers contend that the larger the market the higher degree of adaptation required especially in terms of promotional efforts. This is so because, according to Chhabra (1996), the firm has good reason to bear the added costs of adaptation due to higher sales derived from large markets.

Furthermore, a number of researchers have identified internal, organizational and managerial factors as a crucial contingency that impacts the content of the marketing strategy. The first set consists of the nationality of the company, the nature of the company ownership, the firm's international experience and its market share position. For instance, researchers suggest a correlation between standardization and wholly-owned subsidiary (Ozsomer et al.'s 1991). With regard to managerial attitudes towards international operations, such as the degree of centralization of decision making and corporate orientation, and the extent of management's willingness to accommodate foreign perspective was found to influence the kind of marketing strategy to be adopted (Theodosiou and Leonidou 2003).

Although Theodosiou and Leonidou (2003) assume that contextual factors are significant, they also recognize the role of management action, as articulated in the strategy for achieving its objectives. Management's outlook will influence the degree to which they standardize or adapt their marketing mix (product, pricing, promotion and distribution). From their review of the literature, it emerges that product-related issues exhibited the most degree of standardization. For instance, product attributes, quality, design, and features are found to be the least adapted. The same was also true of branding decisions, which are partly adjusted for semantic, symbolic and cultural reasons.

As for price-related elements, research points out that these are much more adapted, as a result of differences in such factors as marketing objectives, cost structures, inflation rates, competitive policies, and government controls. In general, price adaptation was relatively moderate. With regard to the third element of the marketing strategy, distribution, the authors assert that these are most adapted. This is attributable to both foreign market - (e.g., differences in disposable incomes, purchasing habits, and distribution infrastructure) and company-related (e.g., variations in the level of involvement, product line, and sales volume) reasons. Hence, previous studies stressed the need to adapt the physical distribution to the local requirements involving transportation facilities, infrastructures, warehousing and inventories possibilities. Finally, promotion has exhibited a high degree of adaptation. Many reasons account for adapting promotion due to language differences, media availability, government regulations, economic differences and competitive forces. 
Overall, the literature tends to downplay the role of active agency and resistance in organization-environment relations (Oliver, 1991). Such a narrow focus on processes of conformity to environmental pressures reduces organizations to passivity. For institutional environments are not "iron cages" (DiMaggio \& Powell, 1983). Organizations may be expected to exercise 'strategic choice' (Child, 1972) in relating to their institutional environments and responding to institutional pressures" (Oliver 1991: 170). Elaborating on this important insight, Oliver (1991) suggests a continuum of strategic responses to institutional pressures, ranging from acquiescence, through compromise, avoidance, and defiance. The strategic perspective pays attention to the variety of ways in which organizations may respond to environmental constraints, including industry, economic, cultural and social characteristics.

In lines with the strategic perspective, the present paper wants to emphasize that adaptation to environmental constraints is but one out of many strategic responses. In the next section, an attempt is made to describe one such strategy, referred to as 'transformation' strategy, whereby the organizations may seek to transform the environment confronting it.

\section{Theory of translation}

From a social constructivist perspective, context is shaped by social agents. Its reality (degree of fit to some structure of the world) is a performance, an accomplishment by social actors during processes of translation, negotiations and bargaining. Translation does not only involve concepts, but also translation of interests. The effectiveness of an international strategy is not demonstrated simply by extending it from its original context to foreign markets, but rather. It also requires that the original conditions that support the strategy's effectiveness in the mother country must be recreated in the new context. On this count, there is traffic between the two sites. The interests of the global actors' economic interests are translated into foreign markets' interests in the success of the strategy, thus, into interests in its maintenance and support. If the interaction proves successful, the interests of a global player and those of the local consumers are fused (Callon 1986) and co-aligned.

\section{Participation}

Fusion of interests is achieved through interactions (Knorr-Cetina 1981). Interactions between parties may involve reified elements (such as strategies, budgets, statistics, ratios, documents, standards procedures, policies, designs, plans, budgets, machines, and so forth) (Almeida and Grant 1998), and participatory elements (Mohr and Spekman 1994; Almeida and Grant 1998; Hetrick 2002). Participation involves the mediators or boundary brokers who may accompany such reified artifacts and engage in face-to-face interactions with members of another community (Wenger 1998). Whereas reification refers to coordination mechanisms using codified and standardized forms of information and knowledge, participation involves proximal encounters between the recipients of the business strategy and brokers (whose role it is to help teach, interpret and translate the meaning of reified elements of the strategy to be transferred). Without the participatory role played by brokers, reification can lead to reinforcing the difference between the sites, rather than transcending them (Wenger 1998).

\section{The role of coaches and trainers}

The objective behind both participation and reification is to reduce skepticism, increase the 'rationality' of the strategy to be transferred (insisting that it is a logical solution), its realism (that it is a fact), and that it serves the interests of the transmitters as much as those of the recipients of that strategy. Whereas sites of participation are encounters where expatriates - regarded as sources of certainty - can communicate face-to-face with skeptical recipients, reification is a matter of providing (standard) artifacts and tools that give a more material, tangible load and a more durable form, to the words exchanged among parties. 
Transfer of strategic practices takes place within a context of individuals in interactions. Through interaction, the human mind and body provide a readily available means of carrying and transmitting both tacit and explicit knowledge across borders. Recognizing the difficulties of transferring tacit knowledge across long distances and cultural divides, von Krogh, Ichijo, and Nonaka (2000) emphasize the significance of expatriates, or what they call 'knowledge enablers' who circulate frequently among the farflung outposts of the global corporation, translating corporate strategies and bringing knowledge with them in embodied forms.

It is through coaching and mentoring that translators play a significant role in facilitating the process of transforming the context. Danis and Parkhe (2002) emphasize the role of formal training, company visits and personnel transfers as means of framing the elements of one group's world-view in terms of another group's. Finally, it is crucial to note that translation of interests and concepts does not presuppose a oneto-one relationship between two entities. As noted by Jankowicz (1994), Dobosz and Jankowicz (2002) and Beward et al (2003), in studying the transfer of western business practices to Poland, a large number of management terms did not exist in Polish, such that many of these are introduced in the Polish language, subsequently becoming part of the Polish manager's daily linguistic repertoire. Changing the linguistic repertoire (a contextual feature) is necessary for the success of the western practice in the Polish market. Furthermore, the creation of new concepts is not merely a linguistic invention that leaves reality as it is, but it is most of all an intervention in that context.

\subsection{Reification}

Apart from the use of mentors and translators, reified artifacts, such as machines, rules, directives, routines, strategies, etc (Grant 1996; Almeida and Grant 1998) are central facilitators to the transformation of context. Artifacts, says Fuchs (2001: 306) "make little room for skepticism, especially when they generate rather predictable uniform outcomes across a variety of settings, occasions, times, or operating personnel".

\section{Boundary objects}

Star and Greisemer (1989) have developed the notion of 'boundary objects' to refer to things that link together different social groups but who may view them and use them in quite different ways. Boundary objects may include representations, concepts, documents, artifacts or naturally occurring objects, elements of the physical environment or the inscriptions of instruments (Golinski 1998).

The objects in question must have the character of what Latour (1987) calls 'immutable mobiles' in order to ensure their mobility: "Boundary objects are objects which are plastic enough to adapt to local needs and the constraints of the several parties employing them, yet robust enough to maintain a common identity across sites... They have different meanings in different social worlds but their structure is common enough to more than one world to make them recognizable, a means of translation" (Star and Greisemer 1989: 393).

\section{Standardized forms}

Of particular relevance to the translation process is standardization, as a form of reification. For Latour, standards are a precondition for making a practice work away from the sites of its production, for making it 'travel far without leaving home' (1987: 251). Standardized forms of printed material can circulate and be exchanged by different practices. Standardization also involves the training of personnel in procedures for calibrating instruments, tools and machines. Almeida and Grant (1998) observe that effective transfer and translation of explicit knowledge requires a high degree of formality and standardization of rules and the format of data and compatibility of systems. 
Mintzberg (1979; 1983) distinguishes between standardization of work processes, of work outputs, worker skills' and of norms and values. As argued by many, training enhances the adoption success of new practices (Ahire and Ravichandran 2001; Beyer et al 1997; Dixon et al 1994; Petroni 2002) and eases the work of translation. For, standardization helps to create an understanding that is easily recognizable across different sites and organizational levels (Bateman and Rich 2003).

To sum up this section, interactions between individuals from different sites require both elements: participation and reification. Whereas reification revolves around imposing and implanting an 'alien' form of practice into an 'alien' locale, participation is an attempt to indigenize it. Indeed, the participatory process is characterized by a great deal of negotiations, translation and bargaining. Because what is to be transferred and translated draws its meaning from the context of the strategy in which it is produced, it cannot be transferred to another context without changing the target context so as to match that practice. Recreating or changing the target context in the image of the home context requires a great deal of translation (of terms and interests), negotiation between the parties involved.

It is to be noted that translation aims more to remake and transform the meaning of norms, rules, habits, etc, that prevail in the target context, and less to adapt to them. This is different form previous studies (such as Kostova 1999) where norms and values are taken for granted, as yardsticks to be adapted to. From the present approach, these would emerge mangled in processes of interactions (translation and negotiation). The present approach is more apt to explain how institutions, markets, consumer habits and behaviors, tastes, etc, change, rather than how there are preserved by adapting to them. The next section is devoted to illustrating this framework tentatively developed here using the case of the Swedish furniture retailer, IKEA.

\subsection{IKEA: an Illustration}

Sweden's IKEA has been expanding its operations all over the world. It is a family-owned business with one million visitors a day to 229 stores in 33 countries or regions. Recently it has tapped the Chinese consumer market. IKEA China is posed to increase its sales as the proportion of China's middle class is growing. In the not-so-distant future the size of Chinese domestic furniture market is predicted to be as big as the whole of Europe. IKEA's business concept is based on stylish but inexpensive Scandinavian design furniture. The IKEA logo is blue and yellow, the colors of the Swedish flag. According to Ulf Smedberg, marketing manager of IKEA China, IKEA will have around 10 to 20 stores in three regions by 2010, around Beijing, Shanghai, Guanzhou and Shenzhen.

IKEA's mission is, according to Ulf Smedberg, "to provide smart solutions for homes by implementing three criteria: good design, functionality, and low price". The IKEA business idea is to offer a wide range of home furnishings with good design and function at prices so low that as many people as possible can afford them, without for that matter compromising quality. In a climate that is cold and dark for most of the year, light, bright living spaces that create the feeling of summer warmth indoors all year round are significant features of the Swedish design style. IKEA uses natural materials such as blond woods, natural textiles (linen and cotton), glass, clay, and untreated surfaces. The natural character of these products has bestowed on them a universal utilitarian appeal. IKEA has hardly been the target of anti-globalization activism or sabotage.

At the heart of the IKEA concept is the Swedish home furnishing design created by famous Swedish painters, Carl and Karin Larsson in the 1850's. Consistent with the Swedish lifestyle, the IKEA product range is functional, attractive, child-friendly and family-centered, covering the needs of all family members. Under one and the same roof, customers can find plants, living room furnishings, beds, bookshel- 
ves, toys, frying pans, whole kitchens, etc. Its product range is between 8.000 to 10.000 items, depending on the size of the store and country. Not only is the product range wide in function but also in style. Whatever chair you choose, it is designed to match a table that goes with the bookcase that goes with the armchair, etc. Hence, IKEA provides wholesales home solutions.

The founder of IKEA, Ingvar Kamprad, was born in Småland in the south of Sweden - a region known for being home to many entrepreneurs, of hard-working people, who are adept at using efficiently what little limited resources they can lay their hands on. These humble beginnings of the founder set the tone for the company's cost-consciousness in everything that it does, thereby explaining its low-price approach. Adopting a production-driven approach, IKEA's strategy is to sell a basic product range that is standard and "typically Swedish" to a worldwide public, not paying much regard to what the public actually wants. Over and above product standardization, which helps keep costs down, IKEA seeks price leadership by narrowing down the distance between suppliers and customers in as a cost-efficient way as possible. Furthermore, cost-efficiency is achieved through its use of flat packs, eliminating wasted space, transporting and storing goods more efficiently. In addition, the company asks the customer to do part of the work, by serving themselves, picking the items from the shelves, transporting them home and assembling them themselves. IKEA adopts a standardized product strategy, selling the same products all over the world. For instance, the three best-selling products worldwide are the three products: Billy bookcase, Lack side table, and Ivar storage system. However, although the do-it-yourself (DIY) approach is one of the pillars of IKEA's low price strategy, its extension into China posed difficulty and it was forced to revise some of its components..

\section{Adaptation and standardization}

IKEA's prices proved to be forbiddingly expensive for the segment it was targeting - young, well-educated, professional couples earning high incomes by Chinese standards. A typical IKEA customer earns about Yuan 3,300 (\$399) per month, spending Yuan 300 (\$36) of merchandise per visit. The relatively high prices made customers buy copies of IKEA products at lower prices. IKEA management responded by reducing its prices by 46 percent, in an attempt to make them affordable to a larger proportion of Chinese households and to discourage piracy. As an example, a sofa priced at 2,999 Yuan (US\$363) in 1999 costs now only 995 Yuan (US\$121). Cost-cutting was made possible, among other things, by relocating production units to China.

For another, IKEA adapts its store layout, merchandise display and its home solutions according to the Chinese national and cultural conditions. For instance, its store layouts reflect many Chinese homes and contextual features. For instance, the display shelves were taken down by 10 centimeters (four inches) to make sure that most of the customers could touch the products. Because loud music is considered to convey a welcoming and warm atmosphere in China, store music is louder than in Western stores. Another example of adaptation of its model to the requirements of the Chinese market involves the size of beds. Initially IKEA's stores in China sold Hong Kong-sized beds, which were shorter than standardsized beds, only to realize that those beds were too short for mainland Chinese customers.

Finally, IKEA also had to adapt its location and do-it-yourself (DIY) assembly concept to the Chinese context. Rather than setting up its stores far out in the suburbs as it does in Europe and America, IKEA has built stores near public transportation lines, since a large number of its customers do not own a car. For the same reason, it offers its customers home delivery for a fee. Furthermore, IKEA deviates from the practice of DIY - one of the pillars for keeping costs down - by offering fee-based assembly services. The DIY has not gone down well with Chinese customers. Because of cheap labor customers tend to prefer IKEA's assembly services.

Although IKEA has attempted to adapt to the various contextual and cultural features, it has stubbornly held on to its vision as articulated by its founder: to sell a basic product range that is "typically Swedish". The company also remains a production-driven company, offering the same product range in all countries. As mentioned above, the style is mostly Scandinavian and the product is a clean, 
practical "total solution" to global customer needs. The company emphasizes its Swedish roots, insisting on its "Swedish", yellow and blue colors for its stores.

The IKEA stores are designed exactly in the same way as anywhere else, namely to convey the Swedish home context. Every IKEA store features a restaurant where Swedish meat balls and cinnamon rolls are served, regardless of national tastes. By the entrance, there is a children's playground where customers can drop off their children in order for them to concentrate on their shopping venture. IKEA makes a point of keeping the names of its products in Swedish. With regard to its product range, IKEA has added to the Chinese market only chopsticks, woks and cleavers (Lewis 2005). It is very telling that its 3 bestsellers products are standard all over the world.

\section{Transforming the Chinese context}

Since entering the Chinese market in 1998, IKEA has challenged the Chinese customer's traditional concept of shopping for household goods, of viewing and furnishing their homes and making shopping in IKEA a fashionable experience. Traditionally, Chinese tend to spend most of their time in their livingrooms. Considered as the heart of the home, living rooms are also dining rooms. Kitchens are usually small and, therefore, less money is spent on them. At the same time, bedrooms are supposed to be private and are less furnished. But IKEA is determined to change all that, through the launch of campaigns and other marketing efforts that target these spaces and seek to educate the market. IKEA poses to be a home-furniture expert, helping Chinese consumers how to make the most of their living space, providing hints on how to mix and match colors and designs.

In imposing its business strategy IKEA different methods are deployed; one of these is through teaching Chinese consumers in order to get them to buy-in its concept. Rather than giving up on its DIY concept, the company is actively engaged in teaching its consumers how to assemble products, providing in-store instructions, brochures, TV shows and web demonstrations. One of the brochures depicts a Chinese husband ironing clothes, while the wife is seated in a comfortable sofa watching him. This role-reversal is meant to challenge the conventional Chinese roles, with a view to changing them so as to resemble the original Swedish family context.

IKEA produces brief TV spots that show living areas before and after IKEA's magic touch. TV shows and in-store information aim to educate Chinese consumers and teach them about how to improve the functionality of their homes and how to decorate them. IKEA posts in-store instructions and design advice related to how to do things. For example, one in-store sign portrays an elderly couple whose child just moved away from home to go to college. The couple discusses how IKEA helped them to convert their son's former bedroom into a new room for their use. Traditionally, Chinese consumers are not used to make small, incremental steps when decorating their homes, adopting an 'all or nothing' approach to interior design. Through advertising and different campaigns, IKEA is seeking to instill in Chinese consumers the idea of implementing small, step-by-step changes. As a result, home decoration has become a cultural phenomenon in Chinese homes, creating interior design as a new career path. In addition, new home-decor magazines saw the light featuring the latest news in European design. As the Chinese furniture retailing landscape is changing, and home furnishing habits are being altered, Chinese consumers are becoming receptive to IKEA's concept.

IKEA uses a variety of methods to obtain market data and knowledge on Chinese customer's shopping behavior, their lifestyles, wants and needs. More specifically, it uses "Focus groups, home visits, city visits, telephone surveys, in-store promotions and customer surveys [to] identify what knowledge customers have, how much money they can spend, and what their needs are, be they for storage or decoration, be they simple or complicated," said Linda Xu, head of communications for IKEA in China. Moreover, the IKEA catalogue - the main promotional tool - is distributed in the store and through the mail, being printed in 160 million copies, in 52 editions and 24 languages. 
To sum up, although IKEA's concept is based on a wide range of standard products that are peripherally adapted to local market requirements, it is also geared towards changing the context in the image of the original, Swedish one. The DIY approach, for instance, is so central a component of its business concept and one of the pillars of IKEA's low price strategy. When the DIY approach was introduced to the Swedish consumer, it did not go down easily either, rather the company had to transform the Swedish mentality so as to accept it. In this regard, Swedes' and Chinese's attitudes to DIY are not very unlike.

\subsection{Discussions}

Although this short account does not lend justice to the rich and detailed material of the case, it will suffice for my present purposes, serving as a springboard from which I will present an interpretation which is in line with the suggested framework. The main objective pursued in what follows is to show the significance of transforming the Chinese context, rather than just adapting to it or just providing standardized solutions. Although necessary, adaptation and or standardization are not enough for the success of an international strategy. Strategy is shaped by, but also, shapes its context.

\section{Adaptation, standardization and Transformation}

As noted above, from a contingency perspective, the strategy a firm adopts would depend on a raft of contextual features of the local market. These contextual features or factors are related to the background forces that influence a firm's decision to standardize or to adapt to the context. In the case under consideration, we notice that there are signs of both, of standardization and adaptation. IKEA has made attempts to adapt to the Chinese context: the height of their shelves, loud music in its stores, revising its DIY system, the size of its beds, its distribution structure, its pricing strategies, its locations, etc. All this is consistent with, and well documented in a number of insightful previous studies (see Theodosiou and Leonidou 2003).

However, although IKEA would seem to initially adapt to these requirements, its ultimate aim is to transform the context of Chinese consumers, their ways of decorating and furnishing their homes, and their attitudes towards DIY concept. For, any radical change to IKEA's core model is a threat to its existence, thus, the importance of bringing about major changes in the environment in which the company operates. In many respects, this process of translating IKEA's model can be regarded as an attempt to recreate a featuring a measure of 'Swedishness': Swedish colors and characteristics. Swedish meat bolls, Swedish rolls, and Swedish names of its products are hallmarks of its model. Despite its adaptation efforts, IKEA is holding on to its standardization principle to ensure the globalization of its business model.

\section{The work of translation through translation and reification}

Based on the conceptualization framing this study, the work of translation takes place through two mechanisms: participation (which stresses face-to-face encounters) and reification (involving the use of objects, plans, facts, artifacts, etc). IKEA seeks to change consumers' ways of designing and decorating their homes through in-store instructions, teaching and promotional campaigns during which translators are afforded an opportunity to convey meaning and instilling new Western values and life-styles interacting directly with customers. In addition, the role of reification such as the use of TV shows and Webbased demonstrations and advertising are also effective transformation mechanisms. 
From the present perspective, standardization represents a mode of transforming the context, since as Latour (1987) suggests, standards are a precondition for a strategy to work away from hone without leaving home. The IKEA catalogue works as a reified, immutable mobile that has transformative effects on consumers, standardizing their tastes and needs on a global scale.

Similarly, adaptation can also be regarded as a way of transforming the Chinese context: IKEA reduced its prices not just to adapt to the market demands but mostly to undercut piracy efforts by local manufacturers who set out copying its products and selling them at lower prices. By reducing its prices, IKEA is hoping to retain or gain back its customers who would otherwise be lured by cheaper copies of its products.

Values and lifestyles permeating the West have found their way into the everyday life of Chinese home owners. IKEA's implantation in China has unleashed social and cultural changes, creating new institutions (such as the career of interior decorator, design magazines, etc). Such changes would not have been possible if firms are simply to adapt to the local circumstances. This is the main point made by the present paper: the transfer of a strategy from one context to another entails or presupposes the transformation of the target context. Transforming the target context goes some way to reducing resistance to the company's international strategy.

Contrary to previous research that focused mainly on the couplet adaptation and standardization, the assumption underlying the present work is that context is not to be taken as fixed and stable, but rather as a dynamic one, emerging as a result of traffic, translation and negotiation between IKEA's head offices and Chinese consumers. In order to ensure globalization of their business model, firms need to impose home-office approved practices because the knowledge underlying them is considered fundamental to their business model (Hurt and Hurt 2005, p. 37).

The main argument of the paper is that strategy has a transformative effect on its context. Although previous researchers have recognized the significance of management in this respect, they mainly understood this role in terms of standardization and/or adaptation of their marketing mix (product, pricing, promotion and distribution). There is a need to focus on management action in terms of transformation of the context and the mechanisms used for transforming the context. The paper suggests two main such modes of transforming: participation and reification and the processes of translation they involve. Since it can be assumed that a global international strategy, such as that of IKEA, requires management's ability to transform the target context, more research is needed to investigate the antecedents, the consequences and the measurement of a strategy of transformation in a global context. 


\section{Concluding remarks and implications}

Taking seriously the assumption that strategies are context-bound, the paper has sought to suggest that the extension of a strategy from one context to another entails the transformation of the target context. Translation involves individuals in interactions engaged in processes of translation and negotiation of linguistic terms as well as social interests. Interactions can be direct involving participatory, face-to-face interactions and/or reified artifacts and objects.

IKEA's case provides evidence of adaption to the environment (compliance demands embodied in regulations, norms, laws, and social expectations (Meyer \& Rowan, 1977)), of standardization (a defiance strategy) and also evidence of being actively involved in modifying some environmental elements when found inconsistent with crucial goals and interests.

The present paper emphasizes the significance of firms' efforts to transform the target context. A transformation strategy sheds new light on how to understand the ways in which institutional and cultural settings change over time. Rather than taking stability as the normal state of the world, context is assumed to be in flux, reflecting how the global economic, social environment, competitors and consumers' behavior are in constant change. How can we otherwise understand the sea-wide changes that have taken (and still taking) place in China during the last decade if we do not consider corporations' role in those transformations?

One of the implications of the present performative approach is that (the contextual) reality is something neither given nor to be discovered, but to be actively produced. It is something that is always in the process of being produced by actors as they engage with their daily practices. What previous researchers take as a set of pre-existing, antecedent (external or internal) conditions can be regarded, from the perspective of the present paper, merely as product of the strategic action of management. An international strategy produces its conditions of possibility and managers are regarded as involved in producing the contextual contingencies that are supposed to frame, or serve as stable backgrounds to their action. In corollary, as actors shape their context, they are also shaped by it. This approach accepts that environment factors (such as culture) constitute a structure that constrains actors but that that very structure is made and unmade by agents. Such a position may have significant implications for research into the issue of culture, which has mainly been regarded as an overwhelming force, or an 'iron cage', as cultural factors are often placed front and centre in discussions of foreign market entry strategies.

Finally, in a spirit of self-critique, this paper is exploratory and theoretical. However, it can be regarded as a first step to shift our attention away from a narrow focus on adaptation and standardization onto how contexts shape and are being shaped by the various mechanisms firms deploy and to ponder on the multiplicity of strategic responses as suggested by Oliver (1991). This framework could be used to inform future empirical research. 


\section{References}

Ahire, S.L. and Ravichandran, T. (2001). An innovation diffusion model of TQM implementation. IEEE Transactions on Engineering Management, Vol. 48; pp. 445464.

Almeida. P and Grand, R (1998) 'International Co-operation and Cross-Border Knowledge Transfer in the Semiconductor Industry', Working Paper, Carnegie Bosch School.

Almeida, P and Kogut, B (1999) 'Localization of knowledge and the mobility of engineers in regional networks' Management Science, Vol. 45; pp. 905-917.

Boddewyn, J.J and R. Grosse (1995) 'American marketing in the European Union', European Journal of Marketing, Vol. 29, Issue 12 pp. 23-42

Bartlett, C., and Ghoshal, S. (1989) Managing across borders. Boston: Harvard Business School Press.

Bateman, N. and Rich, N. (2003). Companies' perceptions of inhibitors and enablers for process improvement activities. International Journal of Operations and Production Management, 23(2):185199.

Bedward, D, Jankowicz, D, and C Rexworthy (2003) 'East Meets West: A Case Example of Knowledge Transfer', Human Resource Development International, 6(4):527-545

Beyer, J.M., Ashmos, D.P. and Osborn, R.N. (1997). Contrasts in enacting TQM: Mechanistic vs. organic ideology and implementation. Journal of Quality Management, 2: 339.

Callon, M (1986) 'Some elements in a sociology of translation: domestication of the scallops and fishermen of St. Brieuc Bay'. In Law, J (Ed.) Power, Action and Belief. London: Routledge.

Chhabra, S S (1996) 'Marketing adaptations by American multinational corporations in South America'. Journal of Global Marketing 94 (1996), pp. 57-74.

Child, J. (1972) 'Organizational structure, environment and performance: The role of strategic choice'. Sociology 6: 1-22.

Cavusgil, T S, Zou, S and G.M. Naidu (1993) 'Product and promotion adaptation in export ventures: an empirical investigation'. Journal of International Business Studies 243 (1993), pp. 479-506.

Czarniawska, B (1986) 'The Management of Meaning in the Polish Crisis', Journal of Management Studies, 23(3):313-331.

Danis, W M and Parkhe, A (2002) 'Hungarian-Western Partnerships: A Grounded Theoretical Model of Integration Process and Outcomes', Journal of International Business Studies; 33(3):423-455.

Devinney, T.M., Midgley D.F. and Venaik, S. (2000) 'The optimal performance of the global firm: Formalizing and extending the integration-responsiveness framework', Organization Science, 11: 674-695.

DiMaggio, Paul J., and Walter W. Powell 1983 "The iron cage revisited: Institutional isomorphism and collective rationality in organizational fields." American Sociological Review, 48: 147-160.

Dixon, J.R., Arnold, P., Heineke, J., Kim, J.S. and Mulligan, P. (1994) 'Business process reengineering improving in new strategic directions'. California Management Review, Vol. 36; pp. 93108

Dobosz, D and Jankowicz, D A (2002) 'Knowledge transfer of the Western concept of quality', Human Resource Development International, 5(3):353-367.

Douglas, S P and S C Craig (1986); 'Global marketing myopia', Journal of Marketing Management, Vol. 2; Issue 2, pp. 155-169.

Douglas, S P and Y. Wind (1987) 'The myth of globalization'. Columbia Journal of World Business, Vol. 22, pp. 19-29.

Galbraith, C S (1990) 'Transferring Core Manufacturing Technologies in High Technology Firms', California Management Review, 32(4):56-70.

Grant, R (1996) 'Towards a Knowledge-Based Theory of the Firm', Strategic Management Journal, Vol. 17; Issue, pp.

Gupta, A. K., and Govindarajan, V. (2000) 'Knowledge Flows Within Multinational Corporations', Strategic Management Journal, 21(4):473-496.

Fuchs, S (2001) Against Essentialism: A Theory of Culture and Society, Harvard University Press.

Hetrick S. (2002): 'Transferring HR Ideas and Practices: Globalisation and Convergence in Poland', Human Resource Development International, 5(3):333-351

Holmstrom, C and Spjuth, K (2005) 'Educating Chinese Consumers: Case Studies of IKEA and Absolut Vodka', Master's Thesis, Stockholm University School of Business.

Hurt $\mathbf{M}$ and Hurt, S (2005) 'Transfer of managerial practices by French food retailers to operations in Poland', Academy of Management Executive, May, pp. 37- 49.

Jain , S C (1989) 'Standardization of international marketing strategy: some research hypotheses'. Journal of Marketing 53 (1989), pp. 70-79

Jankowicz, D (1994) 'The Journey to Jerusalem: Mission and Meaning in the Managerial Crusade to Eastern Europe', Organization Studies, 15(4):479-507. 
Jensen, R and Szulanski, G (2005) 'Stickiness and the adaptation of organizational practices in cross-border knowledge transfers', Journal of International Business Studies, 35(6):508-523.

Knorr-Cetina, K (1981) The Manufacture of Knowledge, Oxford: Pergamon Press.

Kostova, T (1999) 'Transnational Transfer of Strategic Organizational Practices: A Contextual Perspective', Academy of Management Review, Vol. 24, No 2, pp 306-324.

Latour, B (1987) Science in Action. Cambridge, Mass: Harvard University Press.

Latour, B (1988) The Pasteurization of France. Cambridge, M A: Harvard University Press.

Levitt, T (1983) "The globalization of markets", Harvard business review, Vol. 61 No. 3 pp. 102-112

Lewis, E (2005) Great IKEA - A brand for all the people. London: Cyan Communications Limited.

Miller, P (2004) 'IKEA with Chinese Characteristics'. The China Business Review, July-August, pp. 36-38.

Mintzberg, H. (1983) Structures in Fives: Designing Effective Organizations. Englewood Cliffs: Prentice-Hall.

Mintzberg, H. (1985) 'Of strategies deliberate and emergent', Strategic Management Journal, pp. 257-72.

Mohr, J. J and Speckman, R. (1994), Characteristics of partnerships success: partnership attributes, communication behavior, and conflict resolution techniques, Strategic Management Journal, 15, p.135-152.

Murtha, T.P., Lenway, S.A. and Bagozzi, R.P. (1998) 'Global mind-sets and cognitive shift in a complex multinational corporation', Strategic Management Journal, 19: 97-114. O

Liver, C 1991 "Strategic responses to institutional processes." Academy of Management Review, 16: 145-179.

Onkvisit and J.J. Shaw (1987) 'Standardized international advertising: a review and critical evaluation of the theoretical and empirical evidence'. Columbia Journal of World Business 22 (1987), pp. 43-55.

Ozsomer, A, Bodur M and S.T. Cavusgil (1991) 'Marketing standardization by multinationals in an emerging market'. European Journal of Marketing, Vol. 25, Issue 12, pp. 50-64.

Perlmutter, H. (1969) 'The tortuous evolution of the multinational corporation', Columbia Journal of World Business, January-February: 9-18.

Petroni, R. (2002). 'Critical factors of MRP implementation is small and medium-sized firms'. International Journal of Operations and Production Management, 22(3):329348

Prahalad, C. K. and Y. Doz. (1987). The multinational mission: Balancing local demands and global vision. New York: Free Press.

Quelch and E.J. Hoff, Customizing global marketing. Harvard Business Review 64 (1986), pp. 59-68.

Ryans, J.K., Griffith, D.A. \& White, S.D (2003), "Standardizations/Adaptations of international marketing strategy: Necessary conditions for the advancement of knowledge". International Marketing Review, Vol. 20 No. 6 pp. $588-$ 603.

Meyer, John W., and Brian Rowan 1977 "Institutional organizations: Formal structure as myth and ceremony." American Journal of Sociology, 83: 340-363.

Star, S. L and J A. Greisemer (1989) 'Institutional Ecology, Translations and Boundary Objects: Amateurs and professionals in Berkeley's Museum of Vertebrate Zoology, 1907-39', Social Studies of Science, (19):387-420.

Terpstra, V and R Sarathy (2000) 'International marketing'. , The Dryden Press.

Theodosiou, M and C L Leonidou (2003) 'Standardization versus adaptation of international marketing strategy: an integrative assessment of the empirical research', International Business Review, Vol. 13; Issue 2, pp: 141171

Von Krogh, G.; Ichijo, K.; and Nonaka, I. (2000) Enabling knowledge creation: How to unlock the mystery of tacit knowledge and release the power of innovation. Oxford, U.K.: Oxford University Press.

Wenger, E. (1998) Communities of Practice: Learning: Meaning and Identity. Cambridge University Press. Cambridge, UK.

Yip, G S, P.M. Loewe and M.Y. Yoshino (1988) 'How to take your company to the global market'. Columbia Journal of World Business 23 Winter, pp. 37-48.

\section{Web sites}

www.IKEA.cn <http://www.ikea.cn/> accessed 2005-12-04

http://www.IKEA-group.IKEA.com/press/press release.html <http://www.ikea

group.ikea.com/press/press_release.html> accessed 2005-12-04

http://www.IKEA.com/ms/en_CN/about_IKEA_our_vision/better_life.html

<http://www.ikea.com/ms/en_CN/about_ikea_our_vision/better_life.html > accessed 2005-12-11. 


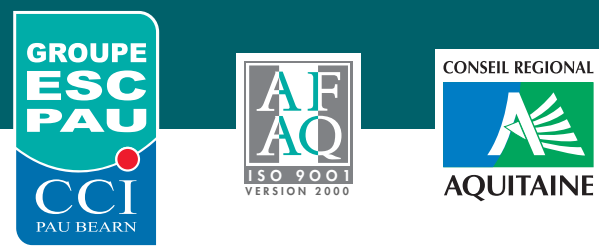

GROUPE É C L E S UPÉRIEURE DE COMMERCE DE PAU

Campus Universitaire 3, rue Saint-John Perse - B.P. 7512 - 64075 PAU Cedex - France Tél. 33 (0)5 59926464 - Fax: 33 (0)5 59926455 - info@esc-pau.fr - www.esc-pau.fr

ESCPAU Bangalore Office : SP Ramanna N²9, 9th Main Shivanagar Bangalore 560010 - India ESCPAU Washington Office : 6601 Rivercrest Court. Bethesda, MD 20816 -2150 - USA

Membre de la Conférence des Grandes Écoles et du Chapitre des Grandes Écoles de Management - Membre de la Fondation Nationale pour l'Enseignement de la Gestion des Entreprises (FNEGE) - Membre Fondateur de Pyrénées-Océanes Campus - Membre de l'European Foundation for Management Development (EFMD) - Membre de l'Association to Advance Collegiate Schools of Business (AACSB) - Membre du Consejo Latinoamericano de Escuelas de Administración (CLADEA) - Membre du Consejo de Rectores de las Universidades Chilenas (CRUCH) - Membre du Centre de Management Euro Amérique Latine (CMEAL) Membre de la Conférence des Recteurs et des Principaux des Universités du Québec (CREPUQ). 